Ore Geology Reviews

August 2018, Volume 99, Pages 314-343

http://dx.doi.org/10.1016/i.oregeorev.2018.06.006

http://archimer.ifremer.fr/doc/00445/55633/

(c) 2018 Elsevier B.V. All rights reserved.

\title{
Volcanic and hydrothermal processes in submarine calderas: the Kulo Lasi example (SW Pacific)
}

\author{
Fouquet Yves ${ }^{1,{ }^{*}}$, Pelleter Ewan ${ }^{1}$, Konn Cecile ${ }^{1}$, Chazot Gilles ${ }^{2}$, Dupré Stephanie ${ }^{1}$, \\ Alix Anne-Sophie ${ }^{1}$, Chéron Sandrine ${ }^{1}$, Donval Jean-Pierre ${ }^{1}$, Guyader Vivien ${ }^{1}$, Etoubleau Joel ${ }^{1}$, \\ Charlou Jean-Luc ${ }^{1}$, Labanieh Shasa ${ }^{2}$, Scalabrin Carla ${ }^{1}$
}

${ }^{1}$ Ifremer, REM-UGM-LGM - ZI de la pointe du diable, CS 10070, 29280 Plouzané, France

${ }^{2}$ Université de Brest - IUEM, ZI de la pointe du diable, 29280 Plouzané, France

*Corresponding author : Yves Fouquet, email address : fouquet@ifremer.fr

\begin{abstract}
:
The study area is located at the transition between the northern end of the Tonga Trench and the North Fiji fracture zone, where tectonic movements are reputed to be the fastest in the world. To the southeast of Futuna Island, a broad area of volcanism occurs within a region characterized by a change in the tectonic fabric between a NE-SW oriented volcanic graben and the N-S oriented Alofi ridge. In 2010, the active volcano Kulo Lasi, which represents the most recent volcanic episode in the Futuna area, was discovered in the center of this extensive volcanic zone. Kulo Lasi is a $20 \mathrm{~km}$ diameter shield volcano that rises $400 \mathrm{~m}$ above the seafloor. It is composed of basaltic to trachy-andesitic lava with no obvious geochemical affinity with the Tonga subduction that occurs $500 \mathrm{~km}$ to the east. The central caldera is 5 $\mathrm{km}$ in diameter and $300 \mathrm{~m}$ deep and is located at a water depth of $1500 \mathrm{~m}$. Diving operations with the submersible Nautile and high-resolution AUV mapping, have revealed the presence of numerous active and inactive hydrothermal fields on the floor and the walls of the caldera. Four tectono-volcanic stages can be distinguished at Kulo Lasi caldera. In stage 1, the shield volcano is built. Annular reverse faults develop at the summit and control circulation of water/rock-dominated hydrothermal fluids and hightemperature alteration of rocks along the nascent normal faults. Mixing of hydrothermal fluids with seawater is favored along normal superficial faults, leading to the formation of low-temperature Fe/Mn mineralization at the summit of the volcano. During stage 2, the caldera collapse, gradually revealing outcrops of the altered and mineralized zones formed during Stage 1. As the magma chamber cools and collapses, less heat is available. As a result, medium to low-temperature $\left(<100^{\circ} \mathrm{C}\right) \mathrm{Fe} / \mathrm{Si}$ deposits form on the floor of the caldera. In stage 3, refilling and ascent of the magma chamber at depth promote the uplift of a central resurgent dome devoid of recent lava emission. The depth of the magma chamber under the dome is estimated to be $1.6 \mathrm{~km}$. Annular dykes feeding the new lava flows are controlled by the deep reverse faults at the outer rim of the caldera floor. The eruptive events are accompanied by short-lived emission of magmatic fluids, rich in SO2, materialized by the presence of native sulfur depositions on the surface of the most recent lava flows. During stage 4 (present day), black smoker sulfide chimneys, controlled by the deep reverse faults, form at the surface of the most recent lava flows at the outer part of the caldera floor. The fluids emitted result from the mixing of a deep fluid of the water/rock reaction type and of shallow seawater superheated in contact with the hot dykes. Hydrogen is generated during reaction of seawater with the hot dikes and $\mathrm{H} 2$ is enriched in the mixed fluids. Active $\left(43^{\circ} \mathrm{C}\right)$ siliceous chimneys at the base of the caldera walls and low-temperature vents $\left(6^{\circ} \mathrm{C}\right)$ perched on
\end{abstract}


the caldera walls suggests a decrease in the venting temperature at a distance from the floor of the caldera. In chimneys, the sphalerite/pyrrhotite/isocubanite/barite paragenesis, probably linked to the high $\mathrm{H} 2$ concentrations in the fluids, indicate unusual reducing conditions for a back-arc. The sulfide mineralization also has unusual trace element concentrations. The concentration in $\mathrm{Pb}$ and $\mathrm{Ba}$ appears characteristic of back-arc environments while the enrichment in $\mathrm{Co}, \mathrm{Se}$, and $\mathrm{Sn}$ is more common to mineralization associated with basalt in mature back-arcs and associated with ultramafic rocks on mid ocean ridges.

\section{Graphical abstract}

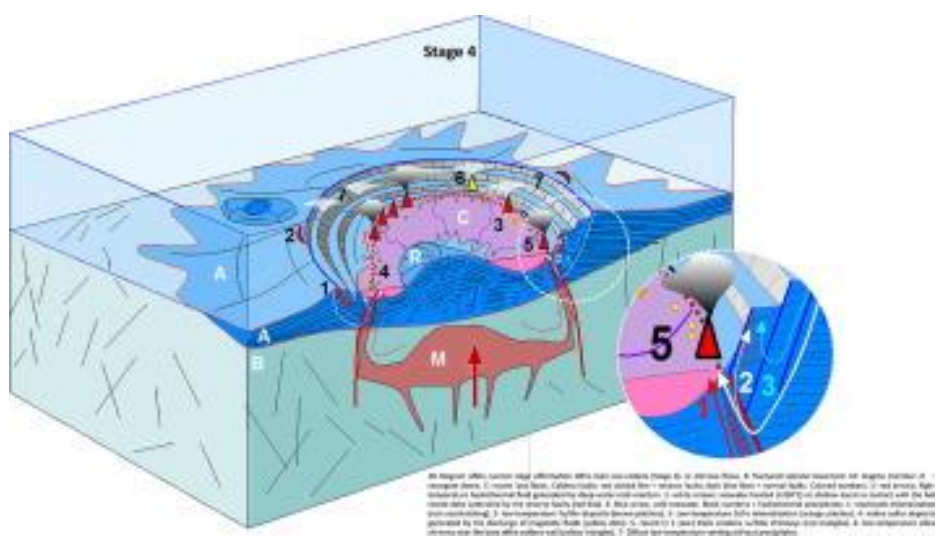

\section{Highlights}

A new major active submarine caldera in a back-arc environment. Different types of hydrothermal deposits in relation to the different stages of eruptive events and collapse of the caldera. Venting different types of fluids. Unusual mineralogy and chemistry for back-arc mineralisation.

Keywords : Subaqueous volcanism, hydrothermal activity, Kulo Lasi caldera, sulfides, SW Pacific 


\section{Introduction}

\subsection{Hydrothermal activity in back-arc environments}

Since the late 1980s, arcs and back-arc basins have attracted the attention of economic geologists because the vast majority of ancient Volcanogenic Massive Sulfides (VMS) deposits mined on land are believed to have formed in this type of environment. For example, several major hydrothermal deposits are known to occur along the Kermadec volcanic arc (e.g., (Baker et al. , 2005, Baker et al. , 2012, Berkenbosch et al. , 2012, de Ronde et al. , 2001, Leybourne et al. , 2012a), in the Lau Basin (Baker et al. , 2010, Baker et al. , 2006, Bertine and Keene, 1975, Evans et al. , 2017, Fouquet et al. , 1991, Fouquet et al. , 1993, Hawkins et al. , 1986., Herzig et al. , 1998, Kim et al. , 2009, Lisitsyn et al. , 1992, Lupton et al. , 2009, Massoth et al. , 2007, Von Stackelberg, 1988)\}, in the North Fiji Basin (Auzende et al. , 1995, Bendel et al. , 1993, Halbach et al. , 2001, Ishibashi et al. , 1994), in 
the Manus Basin (e.g., (Auzende et al. , 1996, Bach et al. , 2007, Binns and Scott, 1993, Both et al. , 1986, Gamo et al. , 1997, Gemmell et al. , 1999, Gena et al. , 2001, Kim et al. , 2004, Lisitsyn et al. , 1993, Moss and Scott, 2001, Petersen et al. , 2005, Taylor et al. , 1986), in the Mariana basin (e.g., (Baker et al. , 2008, Baker et al. , 2005, de Ronde et al., 2014a, Hein et al. , 2014, Ishibashi et al. , 2006, Resing et al. , 2007) and in the Okinawa basin (Glasby, 2008, Halbach et al. , 1989, Halbach and Pracejus, 1993, Hou et al. , 2005, lizasa et al. , 1992, Kimura et al. , 1988, Monecke et al. , 2014, Noguchi et al. , 2007). Exploration over the last 30 years has shown that intense hydrothermal activity occurs along the back-arc ridges and on a high proportion of submarine volcanoes of island arcs (de Ronde et al. , 2003, de Ronde and Stucker, 2015). The volcanic and tectonic instability of back-arc basins and the wide variability of the associated volcanic rocks generate extremely varied hydrothermal fields with respect to fluid composition and mineralization (de Ronde et al. , 2015, de Ronde and Stucker, 2015, Resing et al., 2011). Back-arc basins can be classified into different types (Monecke et al. , 2014). Young basins can develop within continental crust (e.g., Okinawa Basin, Woodlark Basin) or island arc crust (e.g., Lau Basin, Manus Basin) while the most evolved back-arc basins (e.g., North Fiji Basin and central Manus) are dominated by tholeiitic basalt and the corresponding mineralizing processes here are very similar to those that occur on mid-ocean ridges (MOR) (Bendel et al. , 1993).

\subsection{Caldera formation and fossil mineral deposits}

Caldera volcanoes represent an important ore-forming environment for a range of deposit types, including porphyry copper, epithermal deposits, polymetallic veins, and volcanogenic massive sulfide (VMS) deposits (Elston, 1994, Mueller et al. , 2009, Rytuba, 1994, Stix et al. , 2003). Large ancient VMS deposits are found in paleo back-arc environments and show a close spatial and temporal relationship with silicic submarine calderas (Ohmoto, 1978, 1996, Ohmoto et al., 1983). For example, the Kuroko VMS deposits are associated with clusters of subaqueous calderas (Ohmoto, 1978, 1996, Ohmoto et al. , 1983).

Calderas are formed by the collapse of the top of the volcano after eruption of a large quantity of magma from a subsurface reservoir. They can also form following the withdrawal of magma beneath the volcano. The collapse is triggered by large-volume eruptions and sustained effusive volcanism that partially drain high-level magma chambers (Acocella, 2007, Kennedy and Stix, 2003, Lipman, 1997, Mueller et al. , 2009). The subsurface magma provides the heat and magmatic volatiles that drive the overlying hydrothermal systems. Permeability associated with the caldera faults focuses the hydrothermal circulation (Eddy et al. , 1998). The size of the calderas can vary from 2 to $100 \mathrm{~km}$ in diameter (Lipman, 2000). 
Calderas display near-circular geometry, with ellipsoidal forms consistent with multiple eruptive events and regional tectonics (Mueller et al. , 2009). In recent years, monitoring of caldera collapse (Geshi et al. , 2002), analog experiments (Acocella et al. , 2000, Geyer et al. , 2006, Kennedy et al. , 2004, Roche et al. , 2000) and numerical modeling (Gudmundsson, 1998) have considerably increased our understanding of caldera formation. For example, field and experimental works (Branney, 1995, Kennedy and Stix, 2003, Kennedy et al. , 2004, Kennedy et al. , 2008, Lavallee et al. , 2004, Roche et al. , 2001, Roche et al. , 2000, Stix et al. , 2003) have shown that the principal caldera ring faults, which form as a result of magma-chamber evacuation, dip vertically or outwards. These latter are reverse faults forming a ring with a comparatively smaller diameter relative to the topographic rim of the caldera. A second set of normal faults, associated with late-stage peripheral extension, dip inwards and are located on the margins of the caldera. These two sets of faults provide an ideal fracture system for fluid circulation and ore formation (Stix et al. , 2003).

\subsection{Hydrothermal activity in modern deep submarine calderas}

Sulfide deposits in modern submarine calderas are documented in the deep ocean in about 29 hydrothermal fields (Table 1). Eleven sites are located in back-arc environments, sixteen are related to arc volcanoes, and only two are known on MORs. However, on fast-spreading ridges, the processes involved in the formation of the axial summit graben are similar to those involved in caldera formation as demonstrated by field observations, depth of the magma chamber, and analog models (Lagabrielle and Cormier, 1999, Lagabrielle et al. , 2001). In the modern ocean, calderas form at relatively shallow water depths compared to typical hydrothermal fields on mid-ocean ridges, and only two have been identified at a depth greater than $2000 \mathrm{~m}$. In back-arc settings, the dominant lavas are basalt and andesite, while island arcs lavas are more felsic (Table 1).

Among these calderas, only a few have been studied in any detail using a combination of high resolution mapping and/or diving operations. Major detailed studies are along the Tonga-Kermadec arc and on the Brothers caldera (Baker et al. , 2012, Berkenbosch et al. , 2012, de Ronde et al. , 2005, de Ronde et al. , 2011, Embley et al. , 2012, Gruen et al. , 2014, Tontini et al. , 2012, Wright and Gamble, 1999), and Volcano 19 (Stoffers et al. , 2006); and along the Izu-Bonin arc: Suiyo seamount (Marumo et al. , 2008), Myiojin Knoll (Honsho et al. , 2016) and Bayonnaise knoll (Honsho et al. , 2015). In contrast with hydrothermal systems on MORs, the involvement of magmatic fluids rich in metals has been demonstrated in several back-arc basins sites (Berkenbosch et al. , 2012, Berkenbosch et al. , 2015, Butterfield et al. , 2011, de Ronde et al. , 2001, de Ronde et al. , 2015, de Ronde et 
al. , 2011, de Ronde and Stucker, 2015, Herzig et al. , 1998, Resing et al. , 2007, Yang and Scott, 1996).

\subsection{Objectives}

The Alaufi cruise (geophysics and seabed mapping), conducted west of Futuna in 2000, revealed the existence of an active volcanic ridge and recent volcanic areas to the south and east of Futuna Island (Pelletier et al. , 2001). The Kulo Lasi volcano was discovered in 2010 during regional mapping to explore the French Exclusive Economic Zone (EEZ) (Fouquet et al. , 2015). Vertical and tow-yo hydrocasts have revealed intense hydrothermal activity (Konn et al. , 2016) in the Kulo Lasi caldera. In this publication, we present results obtained on the Kulo Lasi volcano in 2010 (Futuna 1 cruise) and 2012 (Futuna 3 cruise). Local highresolution bathymetry and seafloor backscatter images were completed in the caldera using an Autonomous Underwater Vehicle (AUV). Seven dives (six in 2010 and one in 2012), using the manned submersible Nautile, were then performed to explore and sample volcanic rocks, hydrothermal products, fluids and animals within the caldera. Several active and inactive hydrothermal sites were discovered (Fouquet et al., 2015). During the dives, preliminary observations of biota associated with the active vents was also made. We present detailed geological data based on high-resolution maps and on seafloor observations using the manned submersible Nautile. We also discus compositions of fluids and of hydrothermal deposits in relation to the evolution of the volcano. Our data provides insights into the factors controlling the location, type, and timing of hydrothermal discharge in submarine calderas. The young age of this volcano, combined with the availability of high-resolution data make it a suitable locality at which to investigate the volcano-tectonic controls and temporal succession of different types of hydrothermal mineralization in back-arc calderas with effusive volcanic activity.

\section{Materials and methods}

\subsection{Seabed mapping, AUV, and Nautile submersible}

The regional bathymetric maps and seafloor backscatter images were mainly acquired at 8 knots with the ship-borne Kongsberg EM122 multibeam echosounder (12 kHz) installed on the R/V L'Atalante. Data were processed with Caraibes and Sonarscope/3DViewer softwares developed at IFREMER. The resolution of the maps reaches 25 and $10 \mathrm{~m}$ for the bathymetry and seafloor backscatter, respectively. Some surveys conducted at lower speed (5 knots) in the Kulo Lasi area led to even better resolution, with $10 \mathrm{~m}$ and $5 \mathrm{~m}$ for the bathymetry and seafloor backscatter resolutions, respectively. 
The high-resolution bathymetric map of the central Kulo Lasi caldera was constructed using a Kongsberg/Simrad EM2000 multibeam echosounder (200 kHz $1.5 \times 3.5^{\circ}$ ) (CNRS Geoazur equipment) integrated in an AUV (AsterX, IFREMER) that was navigated at $70 \mathrm{~m}$ above the seafloor at 3 knots with survey lines spaced by $200 \mathrm{~m}$. Acoustic data were processed to provide 2 and $0.5 \mathrm{~m}$ resolution for the bathymetry and seafloor backscatter maps, respectively. In addition to the bathymetric multibeam survey, a magnetometer (INSU/IPG /Paris) and a CTD were installed in the AUV during the mapping operations. Details on the AsterX AUV, and the navigation and the EM2000 multibeam payload can be found in (Dupre et al. , 2008). Six AUV dives of 8 hours each were carried out to cover the Kulo Lasi caldera area $\left(35 \mathrm{~km}^{2}\right)$ corresponding to a $225 \mathrm{~km}$ long track.

\subsection{Fluid samples analyses}

In order to collect duplicate samples of hot fluids from different vents, titanium samplers of $750 \mathrm{~mL}$ capacity were deployed in pairs and manipulated by the arm of the Nautile submersible. The samplers were specially conditioned to avoid outgassing and gas leakage during recovery and on-board gas extraction. The temperature of the sampled fluids was measured by using autonomous sensors (Micrel-NKE sensors) placed on the sampler; $\mathrm{pH}$ and $\mathrm{H}_{2} \mathrm{~S}$ concentrations were measured immediately after recovery of the samples and total gas were then extracted following the procedure as described in (Charlou and Donval, 1993). Extracted gases were stored in special gas-tight flasks of 100 or $200 \mathrm{~mL}$ capacity, then separated by gas-chromatography (Agilent GC 7890A, Agilent Technologies) and quantitatively analyzed by triple detection using mass (MS 5975C, Agilent technologies), flame ionization and thermal conductivity detectors. Preliminary concentrations of major gases $\left(\mathrm{CO}_{2}, \mathrm{H}_{2}, \mathrm{CH}_{4}\right.$, and $\left.\mathrm{N}_{2}\right)$ were obtained on board using a portable microsensor Technology Instruments Inc. chromatograph coupled to the gas extractor. Aliquots of gas were stored in vacuum-tight tubes (Labco, Ltd.) and sent for carbon isotope studies (Isolab b. v., Netherlands). After gas extraction, hydrothermal solutions were transferred either to acidcleaned polyethylene bottles for major and minor elements analysis or to precombusted glass bottles for extraction of organic compounds. Major elements including anions $(\mathrm{Cl}, \mathrm{Br}$, and $\mathrm{SO}_{4}{ }^{2-}$ ) and cations ( $\mathrm{Na}, \mathrm{Mg}, \mathrm{K}$, and $\mathrm{Ca}$ ) were measured by ion chromatography (Dionex Ion Chromatograph System 2000) after appropriate dilution. $\mathrm{Fe}, \mathrm{Mn}, \mathrm{Cu}, \mathrm{Zn}, \mathrm{Sr}, \mathrm{Li}$, and $\mathrm{Rb}$ were measured by flame atomic absorption spectrometry using standard additions (Aanalyst, Perkin Elmer Inc.). Aliquots for silica determination were immediately diluted 100- to 200-fold and analyzed on board using the silicomolybdate automatic colorimetric method. In addition, dissolved organic compounds were recovered from fluids on board using stir-bar sorptive 
extraction and then qualitatively analyzed by gas chromatography - mass spectrometry on a 6890 - 5973N GC-MS from Agilent (Konn et al. , 2009, Konn et al. , 2018).

\subsection{Rock sample analyses}

Samples collected by dredges or during the dives were characterized and prepared directly on-board. Rocks were cut and then dried in an air oven at $50^{\circ} \mathrm{C}$. A representative portion of each sample was ground to a fine powder using an agate mortar. Mineralogical and quantitative chemical data were acquired using $\mathrm{X}$-ray techniques (X-ray diffraction and X-ray fluorescence) at the Laboratoire de Géochimie et Métallogénie at IFREMER institute (Brest, France). X-ray diffraction (XRD) analyses were conducted with a BRUKER AXS D8 Advance and a BRUKER D2 PHASER diffractometer. Samples were top loaded into 2.5-cm-diameter circular cavity holders, and analyses were run between $5^{\circ}$ and $70^{\circ} 2 \theta$, in steps of $0.01^{\circ} 2 \theta$ at 1s/step (monochromatic $\mathrm{Cu} \mathrm{Ka}$ radiation, $40 \mathrm{kV}, 30 \mathrm{~mA}$ ). Minerals were identified using Diffrac Suite EVA software. X-ray fluorescence analyses were conducted with a wavelength dispersive X-ray fluorescence spectrometer (WD-XRF; BRUKER AXS S8 TIGER) on fusion beads (for major elements) or compressed pellets (for trace elements). After data acquisition, the measured net peak intensities, corrected for inter-element effects, were converted into concentrations using calibration curves generated from analysis of certified geochemical standard powders (measured under identical analytical conditions). Calibrations were established using a set of certified materials obtained mainly from the Canadian Certified reference materials Project (CCRMP) (for example, CCU-1, CZN-1, Fer-1, PTC-1 or PTM-1) Geological Survey of Japan (GSJ)(JP-1) and the Centre de Recherches Pétrochimiques et Géochimiques in France (CRPG)(BE-N). For sulfur isotopes, sampling was done in two ways: (1) micro-drilling of polished sections, and (2) separation by hand under a binocular microscope. The collected minerals were digested in inverted aqua regia and then purified by elution through a cationic resin to remove any interfering matrix. The solution was analyzed by a Neptune MC-ICP-MS at (PSO- UBO/IFREME-Brest).

\section{Geological setting and morphology of the Kulo Lasi volcano}

\subsection{Regional setting and morphology of the volcano}

The Futuna Islands (Futuna and Alofi), are located south of the ancient subduction zone of Vityaz, in the junction area between the Lau back-arc basin and the North Fiji back-arc basin 
at the eastern end of the North-Fiji transform fault (Figure 1). The study area is located about $200 \mathrm{~km}$ to the west of the northern tip of the Tonga trench. The fastest plate velocity recorded on earth (18 to $24 \mathrm{~cm}$ per year) (Bevis et al. , 1995) is located in this area. The sinistral North-Fiji transform zone connects the northern end of the Tonga trench to the spreading axis of the North Fiji back-arc basin and passes through the northern edge of the Fijian platform (Pelletier et al. , 1998, Pelletier et al. , 2001). The islands of Futuna and Alofi are located along this fault and are regularly subject to both superficial and local earthquakes of high magnitude (Pelletier et al. , 2001).

The Kulo Lasi volcano is situated about $100 \mathrm{~km}$ SE of Futuna Island. North of the volcano, the main faults are oriented NE-SW, while in the south, the regional tectonic structure fabrics are progressively folded to a nearly N-S orientation (Figure 2). The volcano is active and is superimposed on a highly tectonized, but young volcanic basement (Figure 2). Given the absence of sediments in the backscatter images, the basement appears to have formed during several episodes of extremely recent volcanic events. The older, partly sedimented area, south of Futuna Island and at the west of the volcano, is host to two groups of faults; the oldest of which are oriented NNE-SSW and the younger are N-S. Thus, the nontectonized Kulo Lasi volcano represents the youngest known volcano in the investigated area south Futuna volcanic domain.

The Kulo Lasi volcano is about $20 \mathrm{~km}$ in diameter and $360 \mathrm{~m}$ high and has a relatively flat summit located at a depth of $1200 \mathrm{~m}$. It is composed of a succession of non-tectonized lava flows (Figure 3). Close to the summit are three flat-topped and circular volcanic cones of about $2 \mathrm{~km}$ in diameter and $150 \mathrm{~m}$ high. Two of them have a central deep crater and one has a small mound in the center. This type of volcanic cone is common in the Futuna area and has been described in many places along MOR and near Hawaii. They form as submarine lava ponds continuously overflow, forming a circular structure with a flat horizontal top and steep pillowed margins (Clague et al. , 2000). Factors that facilitate the construction of these structures include: effusive eruption, low volatile content, moderate to high confining pressure, long lived steady eruption, moderate effusion rates and relatively flat slope (Clague et al. , 2000).

The caldera is sub-circular, with an outer diameter of $5.6 \times 4.5 \mathrm{~km}$ and contains a $1.5 \mathrm{~km}$ in diameter central resurgent dome. The internal diameter of the caldera is $4.2 \times 3 \mathrm{~km}$. Between the resurgent dome and the caldera walls, the flat bottom of the caldera is covered by recent lavas. The inner walls are composed of tilted old lava flows, talus, huge boulders, and angular blocks. The central resurgent dome consists of tectonized lava due to the uplift of the 
old caldera floor. The recent lava flows at the bottom of the caldera are formed of pillow, lobate, and ropy lavas that cover scoriaceous lava or pillow lava. These different lavas are all rich in fresh glass. Even though the floor of the caldera is extremely young, as determined by combining high-resolution mapping and dives observations, it is possible to identify several generations of flows, most of which appear to have fresh surfaces. The absence or paucity of sediment and weathering attests to very recent volcanic activity in the NW and S sectors of the caldera. Lava flows in the SW and central parts appear to be older and sometimes show light sediment coverage. The SE margin of the caldera floor is covered by very recent flows. The Kulo Lasi volcano is volcanically and hydrothermally active today, as is demonstrated by the numerous active hydrothermal sites and hydrothermal plumes discovered inside the caldera (Konn et al. , 2016).

\subsection{Morphology of the caldera based on high-resolution bathymetry}

The bathymetry (Figures 3 and 4) reveals four types of terrains: (1) The caldera walls, which are almost vertical and up to $300 \mathrm{~m}$ high; (2) the outer part of the caldera floor, formed of old collapsed volcanic lava flows that are tilted towards the center of the caldera and marked by numerous normal faults oriented parallel to the main caldera walls; (3) the resurgent central dome which has been affected by a NE-SW oriented tectonic fabric. (4) Fresh lava flows on the floor of the caldera. The total volume of lava emitted by the Kulo Lasi $\left(27 \mathrm{~km}^{3}\right)$ before the formation of the caldera is estimated considering the average diameter of the volcano (17 $\mathrm{km})$ and its height $(360 \mathrm{~m})$, before the collapse, estimated from the slopes.

\subsubsection{Caldera walls}

The inner wall of the caldera is asymmetric with the western side composed dominantly of tilted old lavas and a steep and narrow eastern side composed of abundant volcanic scree (Figure 4).

The northern wall, traversed during dive \#1, consists of recent lava scree, often sorted and lacking sedimentary cover. The slope contains a number of steps marked by normal faults before reaching the caldera floor. The base of the wall is vertical and has been flooded by very recent lobate lava flows that infill the caldera floor. The surface of this lava is typically a shiny glass. One of the dives along the base of the western side of the caldera (dive \#4) mapped only talus and scree generated by the collapse of several lava flows. The collapse formation here is about one kilometer wide. When presented in $3 D$, the high-resolution bathymetry clearly shows a series of old lava flows that are tilted towards the center of the caldera and are reminiscent of stack of pancakes (Figure 4 left part of the image). The 
eastern side of the caldera shows a vertical wall with abundant scree that often covers the entire wall section from the top to the caldera floor. At the base of the wall, on the caldera floor, older pillow lava ridges are buried under recent lava flows. Between these ridges and the base of the caldera wall, a long depression has been filled by recent lava flows that cover the older scree. On this side of the caldera, numerous hyaloclastites are observed near the recent flows. In the depression, a network of large N-S oriented cracks reveals sections of the prismatic flows and indicates extension at the base of the caldera wall. Some of these cracks are lined with active and/or inactive sulfide chimneys about one meter in height. The active chimneys are discharging a clear fluid. Several yellow colored hydrothermal sediment fields are observed around the chimneys. During dive \#5, a complete section along the southern caldera wall showed old tectonized lava and scree at the base, an extensive alteration and mineralized zone exposed on the caldera wall on the upper part of the slope and massive prismatic lava flows at the top of the caldera wall.

\subsubsection{Central resurgent dome}

The resurgent dome consists of old pillow lava flows and tectonized and still forming debris on the slopes. There is no evidence of hydrothermal activity at the top or the base of the dome. The top of the resurgent dome is tectonized and made with volcanic boulders while the slopes show relatively old lavas flows partially covered by scree. In the south, the resurgent dome strikes towards the caldera wall and is again made up of ancient and tectonized basalts. These older lavas are mostly pillows with a few lobate flows often covered by a film of sediment. Some small areas $\left(1\right.$ to $\left.2 \mathrm{~m}^{2}\right)$ of ocher-colored hydrothermal sediments are observed locally and does not seems to be fault controlled. The southern half of the dome appears to be dissected by a series of E-W to SE-NE oriented faults that run parallel to the regional faults observed on the old basement to the north (Figures 3 and 4).

\subsubsection{Recent lava flows}

Most of the area between the caldera walls and the resurgent dome is occupied by recent lavas flows (i.e. pillow lavas, lobate flows, ropy and scoriaceous lava flows). To the north, draped lavas form a recent flow a few meters high on the top of the recent lobate flows (Dive \#1). In the SE part of the caldera, nearer to the walls, the lava flows also appears to be very young; for example, the glassy edges of the pillow lava are very fresh and sediments almost nonexistent. Based on the lava typology, and of their overlapping relationships, five recent eruptive episodes are distinguished in the SE quarter of the caldera (Figure 5). Episode 1 forms pillow lava flows with light sediment coverage at the deepest part (>1500 $\mathrm{m}$ ) of the caldera floor. Episode 2 occurs as scoriaceous lava flows and sheet flows, indicating very fluid lava. Episode 3 is made up of two large sheet flows of SSW-NNW orientations and 
issued from the southern caldera wall. The surface of these flows is very flat (1490m of water depth) and becomes rougher towards the NE, away from the emission area. Episode 4, between 1490 and $1470 \mathrm{~m}$ of water depth, consists of a continuous front of pillow lava lining the south wall of the caldera. These lavas, extremely recent, are devoid of sediments and overlap the lava flows of previous episodes. The last episode, episode 5 , results in narrow flows ( 20 to $50 \mathrm{~m}$ wide for 200 to $400 \mathrm{~m}$ long) parallel and close to $(<100 \mathrm{~m}$ ) the south wall of the caldera and surmounting the lava of episode 4.

\section{Composition of the volcanic rocks}

\subsection{Petrography}

All of the samples recovered by dredges and/or during submersible dives are very fresh. Most of the samples have glassy textures and contain abundant vesicles. A few samples have doleritic textures and contain plagioclase, clinopyroxene, olivine, and oxides. The remainder has a homogeneous mineralogy. Phenocrysts, when present, are of plagioclase and olivine and more rarely, clinopyroxene. The same minerals comprise the groundmass and are disseminated in the glassy matrix. In many samples, the plagioclase and olivine crystals show evidence for quenched crystallization, with dendritic shapes for the olivines and box shapes for the plagioclases.

\subsection{Geochemistry}

Major and trace element concentrations were measured in 49 samples. The samples were recovered by dredging or from submersible dives performed along the caldera walls, inside the caldera, on the resurgent dome and on two satellite volcanoes located on either side of the caldera. The samples can be divided into two groups. Group 1 comprises rocks that were sampled along the caldera walls and old tectonized lava flows. These represent the oldest part of the volcano and were emplaced before caldera formation. Group 2 comprises samples retrieved from the floor of the caldera and the two satellite volcanoes at the top of the caldera. Recent lava flows, from which the samples were collected by submersible, overlap the scree at the base of the caldera walls, thus these lavas are clearly younger and erupted after the caldera collapse.

The Group 1 samples show the largest variations in major elements, with 48.6 to $61.5 \mathrm{wt} \%$ $\mathrm{SiO}_{2}$ and corresponding $\mathrm{MgO}$ from 8.4 to $2.1 \mathrm{wt} \%$. The Group 2 lavas show a more restricted range of compositions: 49.2 to $51.9 \mathrm{wt} \% \mathrm{SiO}_{2}$ and 3.9 to $7.7 \mathrm{wt} \% \mathrm{MgO}$. In the Total Alkali Silica (TAS) diagram (Figure 6 and table 2) all samples plot in the subalkaline field, close to 
the boundary between low- $\mathrm{K}$ and medium- $\mathrm{K}$ volcanic rocks, and range from basalt to andesite in composition.

The major element compositions (Figures 6 and 7) suggest that the two groups of samples have different evolution trends. The Group 1 samples form a standard fractional crystallization trend, indicating removal of plagioclase, clinopyroxene, and olivine from the onset of fractionation with Fe-Ti oxides from 52 wt\% silica. These minerals correspond to those observed in thin section. The Group 2 lavas, however, form a different trend in these diagrams, with lower $\mathrm{Al}, \mathrm{Ca}$ and $\mathrm{Mg}$ contents but higher Fe and Ti contents than the Group 1 lavas.

Rare earth element patterns (Figure 8) show a broad range of compositions for Group 1 lavas, but with parallel patterns and a deeper europium negative anomaly for the most differentiated samples. These patterns are compatible with evolution via fractional crystallization. As expected, Group 2 lavas have a more restricted range of REE compositions, although their patterns are parallel to those of Group 1.

\section{Hydrothermal mineralization}

Six different types of mineralization (figures 9 and 10) were observed and sampled during the dives: 1) Sulfide impregnation in highly altered volcanic rocks; 2) Fe/Mn low-temperature precipitates; 3) low-temperature $\mathrm{Fe} / \mathrm{Si}$ hydrothermal sediments; 4) high-temperature sulfide/sulfate chimneys; 5) active siliceous chimneys; and 6) iron oxides. In addition, also, areas with low-temperature venting without mineral precipitates were observed in many places along the western and southern caldera walls. Observations made during the dives were used to confirm the different acoustic facies identified and delineated in the seafloor backscatter images. These maps show the presence of several extensive hydrothermal sediment formations on the floor of the caldera and zones of hydrothermal alteration on the caldera walls (Figures 11 and 12). No large VMS formation was found. However, the large number and diversity of hydrothermal mineralization allows us discuss the evolution of the different types of mineralization in relation to the caldera geometry and the formation history.

\subsection{Alteration and stockwork mineralization along the caldera wall}

Several zones of intense hydrothermal alteration including disseminated sulfides and local stockwork mineralization were found along the caldera walls. The alteration is extensive and is clearly visible in several places in the high-resolution seafloor backscatter images (Figure 
11). One dredge and two submersible dives were carried out in this locality. One of the largest zone is located near the top of the southern wall of the caldera (Figure 11). A traverse made during dive \#5 revealed scree composed of white blocks of altered lava at the base, overlain by a steep slope containing larger $(>1 \mathrm{~m})$ white blocks of altered lava at depth of between 1340 and $1260 \mathrm{~m}$. The top of the caldera wall $(1200 \mathrm{~m})$ comprises a vertical cliff composed of prismatic lava flows. The alteration zone consists of discolored and bleached lavas impregnated with sulfide that have left ocher residues on the rock surfaces. Some larger blocks exhibits a network of oxidized sulfide veins, indicative of an earlier stockwork zone that has been exposed after the collapse of the caldera along normal faults. A second extensive alteration zone of this type was visited in the NW sector of the caldera, near to the base of the caldera wall and close to the margins of recent lava flows (Figure 13). Two large areas $(100 \times 40 \mathrm{~m}$ and $100 \mathrm{~m} \times 80 \mathrm{~m})$ of altered gray basalt with disseminated pyrite were sampled.

\subsection{Low temperature $\mathrm{Fe} / \mathrm{Mn}$ and $\mathrm{Si} / \mathrm{Fe}$ mineralization}

An inactive hydrothermal site located along the northern upper rim of the caldera (Figure 9) consists of black manganese oxides covering orange iron oxides. This hydrothermal mineralization, which is up to several tens of cm thick, formed on a series of basalt flows and, covers an area several hundred square meters in size. No chimneys were observed in the area.

Inactive accumulations of silica and iron oxides are relatively abundant on the caldera floor at Kulo Lasi (Figures 9 and 12), occurring near the caldera walls throughout the southwestern, northwestern, and northeastern parts. These areas were seen as low backscatter intensity patches in images acquired during the AUV survey and correspond to older low-temperature hydrothermal sites. Several zones of the same type were visited during dives \# 3, 4 and 5 . These appears to form brown-ocher irregular patches of hydrothermal sediments varying from a few tens of meters to $10000 \mathrm{~m}^{2}$ in size. The contact between the hydrothermal sediments and the lava flows is distinct. None of these sites were seen to be active. Most of the formations are located on the outer parts of the caldera floor and a short distance from the base of the walls. Very often, white pelagic sediments almost entirely cover the earlier very friable hydrothermal formations. These have black surfaces covered with manganese oxides and a core of ocher-colored material and are rarely more than a meter thick. Since they lie both on tilted old lava flows (NE part of the caldera) and on undisturbed recent lava flows (SW part of the caldera floor), most of the hydrothermal sediment formations, even not 
active, are considered to be relatively young. They also occur preferentially at the outer part of the caldera.

\subsection{Light orange chimneys near the base of the caldera wall}

A field of siliceous chimneys was seen along the northern edge of the caldera, less than 2 $\mathrm{km}$ east of the black smoker field. Here, the northern wall is marked by older lava scree. The chimneys are composed of a light-orange porous material and measure up to $5 \mathrm{~m}$ in height. The maximum temperature of the transparent fluid is $43^{\circ} \mathrm{C}$ (Figure $10 \mathrm{C}$ ). The chimneys were not sampled, but from their texture, color, the absence of dark color in the broken parts, and the temperature of venting they appear to be similar to the classical silica chimneys observed at many hydrothermal sites in the world's oceans.

\subsection{Active low-temperature diffusion with no precipitates}

In the southwestern sector of the caldera (Figure 9), three small $(<50 \mathrm{~m})$ active hydrothermal sites are currently discharging transparent fluids. In the largest area, a depression is filled with ocher-colored hydrothermal sediment. Close to this site, shimmering and transparent fluids are being released along a fault scarp (1418 $\mathrm{m}$ water depth) at a temperature below $6^{\circ} \mathrm{C}$. The biota here is very dense and varied and comprises various fixed and mobile organisms including white and pink shrimps, crabs, large clusters of siboglinidae worms (Figure 10D) fish mussels and galathea crabs. Two other active vent areas of this type, at water depths of $1372 \mathrm{~m}$ and $1411 \mathrm{~m}$ respectively, occur further west along the slope (Figure 9).

\subsection{Active black smoker chimneys on the caldera floor}

\subsubsection{Location}

Chimneys (either active or inactive) were observed in four of the six dives (Figures 10), with all sulfides-rich chimneys located on the caldera floor in the north-western and eastern sectors of the caldera (Figures 9 and 13). They systematically occur on the most recent lava flows that have been stained by iron oxides. Iron oxides also accumulate as sediments in the depressions. Although small in size (up to 1-2 $\mathrm{m}$ high), the chimneys are locally quite numerous and very active. However, they are all located near the base of the caldera wall, and no high-temperature activity was seen in the central zone of the caldera, or on the walls themselves. The average distance between the chimneys and the wall is $145 \mathrm{~m}(\mathrm{~min} .80 \mathrm{~m}$, max. $240 \mathrm{~m}$ ). The main active areas in the NW of the caldera (Figure 13) strike S-SW/N-NW for approximately $0.5 \mathrm{~km}$ and forms a relatively narrow $(<50 \mathrm{~m})$ alignment near the base of the western caldera wall (Figure 13). The water depths of the high-temperature active 
chimneys are relatively constant, between 1476 and $1478 \mathrm{~m}$ in the west and at $1462 \mathrm{~m}$ depth in the east. Marine organisms are abundant near many chimneys and in areas of diffuse venting. However, only mobile animals such as shrimps, galathea crabs, and fish were seen. No sessile animals were observed, suggesting, like the small size of the chimneys, that hydrothermal activity is extremely recent in this area. Two types of smokers are in the NW area (Figure 13): black smokers with temperatures up to $345^{\circ} \mathrm{C}$ and clear smokers with temperature of up to $332^{\circ} \mathrm{C}$. Anhydrite is the dominant mineral in both types of chimneys. The second active area with sulfide chimneys is on the eastern side of the caldera where chimneys located near a recent crack expel a transparent fluid. The temperature was not measured on these chimneys.

\subsubsection{Fluid composition}

Three smokers on the north-western of the caldera floor were sampled at a water depth of 1475m (Figure 13). Two of the smokers were short narrow chimneys and the other had a beehive structure. Composition of collected fluid is shown on table 3 (Konn et al. , 2018). The fluid sampled from the beehive-form smoker was found to be significantly mixed with seawater (Mg: $49.8 \mathrm{mM}, \mathrm{T}^{\circ}: 134^{\circ} \mathrm{C}$ and $\mathrm{pH}: 6.07$ ). Black and translucent fluids with similar temperatures $\left(342\right.$ and $\left.343^{\circ} \mathrm{C}\right)$ were observed at the different smokers. The clear fluids have a chlorinity $(497 \mathrm{mM})$ lower than seawater, while the black fluids have a chlorinity of up to $735 \mathrm{mM}$ and higher than seawater. Silica concentrations range from $8.4 \mathrm{mM}$ in fluids with low chlorinity, to $14.6 \mathrm{mM}$ in fluids with high chlorinity. The high chlorinity fluids are enriched in metals (maximum: Fe: $9884 \mu \mathrm{M}, \mathrm{Mn}: 1416 \mu \mathrm{M}, \mathrm{Cu}: 20 \mu \mathrm{M}$, and $\mathrm{Zn}: 175 \mu \mathrm{M}$ ) compared to the low chlorinity fluids (maximum: Fe: $4796 \mu \mathrm{M}, \mathrm{Mn}: 862 \mu \mathrm{M}$, Cu:14 $\mu \mathrm{M}$, and Zn: $45 \mu \mathrm{M}$. K (16.6 to $29 \mathrm{mM}$ ), $\mathrm{Li}(149$ to $249 \mu \mathrm{M})$ and $\mathrm{Rb}(26$ to $46 \mu \mathrm{M})$ are highly enriched compared to seawater. Na concentrations (388 to $612 \mathrm{mM}$ ) are principally linked to the chlorinity. $\mathrm{Ca}$ concentrations (10.8 to $11.6 \mathrm{mM}$ ) are similar to that of seawater). Sr (3.4 to $9.4 \mu \mathrm{M}$ ) is extremely depleted compared to seawater.

One specific characteristic is the high concentration of $\mathrm{Mg}(24.6$ and $26.5 \mathrm{mM})$ and $\mathrm{SO}_{4}{ }^{2-}(8.8$ and $6.2 \mathrm{mM}$ ) in the fluids despite the very low pH levels (2.24 and 2.36). $\mathrm{CH}_{4}$ is nearly absent ( $<0.01 \mathrm{mM}$ ) whereas the $\mathrm{H}_{2}$ concentration is variable at a very high level in all samples ( 1 to $19.8 \mathrm{mM}$ ). $\mathrm{H}_{2} \mathrm{~S}$ is up to $5 \mathrm{mM}$ in the low chlorinity fluid, and $0.4 \mathrm{mM}$ in the high chlorinity one. The concentration in $\mathrm{CO}_{2}(5.1 \mathrm{mM})$ is low compared to magmatic dominated fluids (e.g. up to $206 \mathrm{mM}$ in magmatic dominated fluids at Brother seamount (de Ronde et al. , 2011). Due to different solubility, $\mathrm{CO}_{2}$ and sulfur gases $\left(\mathrm{SO}_{2}\right.$ and $\left.\mathrm{H}_{2} \mathrm{~S}\right)$ exsolved at different pressures and may be decoupled (de Ronde and Stucker, 2015). Fluids from the Kulo Lasi volcano are clearly enriched in organic carbon $(\mathrm{TOC}=1.78-3.40 \mathrm{mg} / \mathrm{L}$ compared to seawater $\sim 0.5 \mathrm{mg} / \mathrm{L}$ 
(Bennett et al. , 2011, Lang et al. , 2006, Sharp et al. , 2002). Both aliphatic and aromatic hydrocarbons, as well as fatty acids, were present. The fluids are also enriched in longer chain alkanes (mainly C10 and $\geq \mathrm{C} 16$ ), aromatic hydrocarbons (mainly naphthalene, fluorene, and anthracene mainly) and linear fatty acids (C12 and C16).

\section{Composition of the hydrothermal mineralization}

\subsection{Mineral and chemical compositions of chimneys}

The mineralogy of 16 samples was studied using X-Ray diffraction (major minerals) and reflected light microscopy (major and trace minerals and paragenetic studies). The sulfate chimneys are mainly composed of anhydrite with disseminated pyrrhotite (Figures 14, 15 and Table 4) and rare chalcopyrite and sphalerite. Anhydrite represents almost $100 \%$ of the sample in some cases. Some samples contain significant amounts of pyrrhotite in the form of monoclinic rods. Euhedral pyrite was found to be more common near the exterior of the chimneys (Figure 15-E). Pyrrhotite blades are commonly corroded and partly replaced by pyrite (Figure 15-H).

Most of the inactive chimneys are dominated by sulfide (Table 4). At the core of the chimneys pyrrhotite $(70-80 \%)$ is dominant and pyrite is relatively rare, (Table 4 and figure 15) while sphalerite is dominant $(70 \%)$ near the exterior margins of the chimneys. The sphalerite content gradually increases from the core towards the external part of the chimney where it sometimes forms a massive layer (Figure 14-D, E, G). Chalcopyrite and isocubanite are less abundant and are localized towards the center of the chimneys (Figure 14-H and 15-B, E). Pyrite occurs in the outer margin together with sulfates (barite \pm anhydrite) and iron oxides. Pyrrhotite occurs as blades or hexagons in sizes ranging from a few microns to hundreds of microns (Figure 15-A, C, D). These blades are often mantled by overgrowths of isocubanite and/or sphalerite and sometimes contain inclusions of these minerals. Some sphalerite inclusions form concentric structures. The sphalerite is generally in the form of ovoid aggregates (Figure 14-E, G) with massive to semi-massive or collomorph textures and occurs in the inferred low-temperature outer part of the chimney. Isocubanite appears as anhedral crystals within the massive sphalerite, ranging in size from a few microns to tens of microns. The isocubanite has generally crystallized around pyrrhotite or sphalerite crystals 
but can also occur in isolated forms in association with pyrrhotite, or line the hydrothermal conduits. Chalcopyrite frequently occurs as exsolutions in isocubanite (Figure 14-H) and commonly replaces sphalerite. One of the chimneys in the eastern sector of the caldera is dominated by pyrite. However, the presence of pyrrhotite ghost aggregates (Figure 15-F) is indicative of an early hydrothermal stage dominated by pyrrhotite. In other chimneys, pyrite associated with sphalerite is sub-automorphic and replaces pyrrhotite (Figure 15-D). Galena is often observed within sphalerite (Figure 14-B, D, E) and is mainly sub-automorphic, or xenomorphic, but sometimes present a skeletal habit. The galena is much more abundant in colloform sphalerite in the outer parts of the chimneys and gradually disappears towards the copper-sulfide-rich inner parts. Barite and opal are the most frequent gangue mineral phases. When present, opal is distributed homogeneously as a thin and late precipitate around sulfides and locally may replace pyrrhotite or sphalerite. Opal is considered to be a late phase since its precipitation occurs at relatively low temperatures (i.e., $~ 50-100^{\circ} \mathrm{C}$ ) (Scott, 1997). Barite preferentially develops in the outer chimney zones in association with sphalerite (Figure 14-D) and pyrite.

Chemical compositions of various hydrothermal precipitates were determined by XRF and are presented in table 4. For individual chimneys, several analyses were carried out, each analysis corresponding to either the complete chimney or to a particular zone within the chimney (e.g., a zone rich in pyrrhotite or sphalerite). Analyses can be divided into three groups: (1) sulfate-rich active chimneys dominated by anhydrite. (2) Zn-rich, representing areas enriched in sphalerite ( $\mathrm{Zn}>10 \mathrm{wt} \%)$ and (3) Fe-rich dominated by pyrrhotite (Fe> 40 $w t \%$ ). The sulfate-sulfide chimneys show a wide range of $Z n$ concentrations (from 0.2 to 47.7 wt\%. average $\sim 10 \mathrm{wt} \%)$ and exhibit relatively low $\mathrm{Cu}$ contents (0.2 - $2 \mathrm{wt} \%$ : Average $\approx 1$ wt\%). Cobalt (up to 2664 ppm), selenium (up to 867 ppm), tin (up to 694 ppm), and gallium (up to $734 \mathrm{ppm}$ ) are, in turn, characterized by high values. Concentrations of $\mathrm{Pb}$ (up to1.5 $w t \%$ ), Ba, (up to $5 \mathrm{wt} \%$ ) As (up to 1724) and Ge (up to 324 ppm) are relatively high. Average compositions of sulfide mineralization in other tectonic environments in the modern seafloor are presented in table 5.

\subsection{Mineral and Chemical compositions of hydrothermally altered} lavas

Eleven altered volcanic samples were analyzed to define the main mineralogical and chemical characteristics of the alteration zones. The white color of the leucocratic rocks (Figure 16) indicates strong alteration of the mafic minerals. Among the different alteration minerals present, chlorite, nontronite, and pyrite were identified by XRD in all of the samples. 
The presence of plagioclase and clinopyroxene in the altered samples reflects the mineralogy of the basaltic protolith. Pyritization is relatively high and occurs as millimetersized grains of pyrite that may represent over $10 \%$ of the sample (Figure 16-C). Petrographic studies confirmed the presence of large quantities of subhedral to euhedral pyrites and showed the presence of chalcopyrite, either as isolated grains or as inclusions in pyrite (Figure 16-D, E). Rare pyrrhotite inclusions were also observed in pyrite (Figure 16-F).

The chemical composition of the hydrothermally altered basalt reveals several stages of alterations. Silica has been leached from most samples, and $\mathrm{SiO}_{2}$ concentrations are generally lower than $50 \%$ (31 to $46 \%$ ). Only one sample contained up to $55 \% \mathrm{SiO}_{2}$; this sample also has the highest quartz concentration and is probably silicified. Total sulfur is high (up to $9.4 \%$ ) and reflects the presence of disseminated sulfides. Compared to fresh basalt $(7.7 \% \mathrm{MgO}$ ), all samples, except one, exhibit $\mathrm{Mg}$ enrichment (up to $14 \% \mathrm{MgO}$ ). Potassium (as low as $0.04 \%$ ) has been leached from most samples. Ca (average $0.5 \%$ $\mathrm{CaO}$ ) was completely leached in the alteration zone at the base of the caldera wall (fresh basalt: $12.3 \% \mathrm{CaO}$ ). In the alteration zone near the top of the caldera wall, the $\mathrm{Ca}$ is also leached (average $7 \% \mathrm{CaO}$ ). Only one sample, in which calcite was identified is enriched in calcium. Trace element analysis shows an intense leaching of $\mathrm{Rb}$ in contrast to enrichments in $\mathrm{V}$ and $\mathrm{Ni}$. Barium up to $370 \mathrm{ppm}$ is slightly enriched in some samples. However, no barite was detected by XRD on the altered samples.

\subsection{Mineral and chemical compositions of $\mathrm{Si} / \mathrm{Fe}$ hydrothermal sediments}

The Fe/Si metalliferous sediments are mainly composed of iron oxides, clay minerals (nontronite) and amorphous silica. The poorly crystalline character of some of these mineral phases (ex. opal, goethite, nontronite) makes them difficult to identify using XRD. Amorphous silica likely represents the major component of the sediments.

The results of XRF analysis of these hydrothermal sediments are given in Table 6. Data for the major elements indicate high concentrations of $\mathrm{SiO}_{2}$ (26.2 to $86.6 \mathrm{wt} \%$ ) and $\mathrm{Fe}_{2} \mathrm{O}_{3}$ (4.6. to $53.6 \mathrm{wt} \%$ ), relatively high concentrations of $\mathrm{Na}_{2} \mathrm{O}$ (1.8 to $3.4 \mathrm{wt} \%$ ) and $\mathrm{MgO}(0.4 \mathrm{wt} \%)$ but relatively low concentrations of manganese and aluminum (e.g., $\mathrm{MnO}<1.4 \mathrm{wt} \%$; $\mathrm{Al} 2 \mathrm{O} 3<0.6$ $w t \%$, respectively). This suggests that nontronite is very low in aluminum and manganese oxides (i.e., vernardite, birnessite, or todorokite) represent minor components. These mineralization are characteristic of low-temperature $\left(<100^{\circ} \mathrm{C}\right)$ hydrothermal precipitates. 


\subsection{Sulfur Isotopes}

Fourteen sulfur isotope analyzes were performed on mineral fractions of pyrrhotite, chalcopyrite, sphalerite, pyrite and anhydrite from four inactive and one active chimney. One anhydrite exhibits a high positive isotopic signature of $\delta^{34} S=21.11 \%$ from seawater sulfate (20.9\%). The data obtained for the sulfides are consistent ranging from 1.3 to $3.5 \%$ with an average of $2.3 \%$. Two sphalerite samples and one pyrrhotite sample from the FU-PL06-05 chimney yielded the highest $\delta^{34} S$ values (> $3 \%$ ). The high-temperature minerals, such as chalcopyrite, and pyrrhotite have lower isotope signatures $(<3 \%$ ). The lowest values (i.e., $1.25 \%$ ) were obtained on pyrrhotite sampled by micro drilling at the core of the chimneys. Three pyrite fractions from samples of three different altered volcanic rocks were also separated for sulfur isotope analysis. The $\delta^{34} S$ values are higher than those observed for the sulfides from the chimneys and range between 5 and $9 \%$. The $\delta^{34} S$ of the native sulfur is $3.12 \%$.

\section{Discussion}

\subsection{Regional geological setting and implications of lava composition for the formation and evolution of Kulo Lasi volcano.}

At Kulo Lasi, the two groups of magma appear to have followed a different crystallization path and did not reach the same degree of differentiation. As the $\mathrm{CaO}, \mathrm{MgO}$ and $\mathrm{TiO}_{2}$ contents of the two groups overlap, it is possible that the two magmas had the same starting composition and were derived from the same source. According to the REE patterns, the two series are from a similar magma source but with different evolutionary trends within the magma. Group 2 samples clearly represent a new batch of magma ascending through the Kulo Lasi volcano after the caldera collapse, but with a shorter residence time in the volcano and a different crystallization sequence. Group 2 samples are younger from field observations, we also show that they are less differentiated (see major element diagrams) and they possibly have the same parental magma (see major element diagrams and parallel REE patter, Figures 6, 7 and 8).

The trace element compositions of lavas sampled from large volcanoes in the Lau and Tonga-Kermadec arcs and back-arcs are consistent with their geodynamical setting. They show substantial enrichments in fluid mobile elements (e.g., LILE large-lon Lithophile Elements, such as $\mathrm{Rb}, \mathrm{Ba}, \mathrm{K}$, and $\mathrm{Sr}$ ) and low concentrations of fluid immobile high field strength elements (e.g., HFSE such as Zr, Hf, Nb, and Ta) (Hawkesworth et al. , 1993, 
Tatsumi and Eggins, 1995). These geochemical characteristics are recognized in arc lavas, and to a lesser extent, in back-arc volcanics. In contrast, the samples from Kulo Lasi volcano are not LILE-enriched and do not show HFSE negative anomalies and thus, they do not exhibit the normal geochemical characteristics of back-arc volcanism. In the very complex tectonic setting of the Futuna area, this indicates that the magmatic activity in the Kulo Lasi region is not directly related to subduction.

Several large volcanoes with calderas have been described in the Manus, Lau and TongaKermadec arcs and back-arcs in the SW Pacific area where the Futuna area is also located (see Table 1). Most back-arc calderas are dominated by basaltic or slightly differentiated rocks, while, felsic volcanic rocks and associated pyroclastic products are common in arcs. The felsic volcanoes have steep external slopes, with a large caldera at the summit and are associated with large deposits of silica-rich pyroclastic products (Barker et al. , 2013, Graham et al. , 2008, Wright et al. , 2006). Kulo Lasi volcano is very different from the se large felsic volcanoes. Its very flat shape is more like that of a shield volcano formed mostly from the extrusion and accumulation of mafic lavas. This is also consistent with the fact that the most differentiated rocks sampled so far on Kulo Lasi have only intermediate compositions with no more than $61.5 \mathrm{wt} \%$ silica. No ignimbrite or pumices were sampled by the dredges or observed during the dives. Thus, we suggest that the caldera probably formed through incremental collapse due to frequent and massive outpouring of mafic to intermediate magmas from the summit or flanks of the volcano. The absence of highly differentiated lavas might be explained by the regular input of new basaltic lava to the shallow magma chamber. This is compatible with the intense volcanic activity of the whole SE Futuna area as suggested by the lack of sediments in seafloor backscatter images (Figure 2) in this area and by direct observation during several of the submersible dives. Compared to the surrounding areas, Kulo Lasi volcano is non tectonized. Furthermore, several dives in the recent volcanic area $20 \mathrm{~km}$ north of Kulo Lasi revealed that the most recent lavas erupted on the caldera floor. Thus, Kulo Lasi can be considered the focus of the most recent volcanic activity at the intersection between the regional NE-SW and N-S fault systems (Figures 2 and 3).

\subsection{Caldera formation and fluid pathways}

The structure and shape of collapse and resurgence are often controlled by preexisting discontinuities (Acocella et al. , 2004). The emplacement of the Kulo Lasi volcano is regionally controlled by the crossing of the N25 directions visible at the south and west of the volcano with the N70 direction largely expressed in the north (Figure 2). These two regional 
fault systems are also seen within the caldera. Part of the western collapsed area is controlled by N25 faults. The N70 directions are better expressed at the top and the west side of the resurgent dome. The two types of faults also control the southern extension of the resurgent dome. Thus, the structure and shape of collapse and resurgence are partly controlled by preexisting regional discontinuities and probably explain the slight E-W elongation of the caldera.

Collapse experiments show that the outward dipping reverses ring faults generate the first depression and are followed by an outer concentric depression formed by the inwards dipping normal ring faults (Acocella et al. , 2000). Reverse faults propagate upwards from the magma chamber and then normal superficial faults initiate from tension fractures propagating downwards from the surface (Burchardt and Walter, 2010). When these structures intersect, the resulting higher permeability is favorable for hydrothermal circulation. Cold seawater is drawn down through the normal faults and returns as hot metal-rich fluids along the reverse faults, favoring VMS formation at the base of the caldera walls (de Ronde et al. , 2011, Embley et al. , 2012, Mueller et al. , 2009). In general, the largest massive sulfide deposits preferentially form at the base of the caldera walls. The heat from the magma chamber drives high-temperature convective fluids. These fluids may deposit mineralization where the main fault intersects the seafloor, or where there are permeable pyroclastic rocks in the area of maximum subsidence (Stix et al., 2003). Massive sulfide formation is favored during two stages: (1) during and immediately after caldera collapse and (2) during post-caldera resurgence (de Ronde et al., 2014b).

Theoretical models also indicate that reverse ring faults controlling caldera subsidence will form at the margins of the magma chamber. Consequently, the area covered by the resulting caldera depression will be of the same order as the surface projection of the underlying magma reservoir (Marti et al. , 2008). Calderas develop by increasing their depth/diameter ratio and evolve from a depression controlled by the collapse along the deep reverse ring faults (= structural diameter - Ds) to an enlargement of the diameter controlled by erosion along the wall (= tectonic diameter - Dt) (Geshi et al. , 2012). Mature calderas are characterized by Ss/Ds $>0.07$ (Ss = structural depth of the caldera) (Geshi et al. , 2012). At Kulo Lasi, the position of the deep reverse faults is materialized by the last eruptive episode rooted on annular dikes close to the base of the walls. Based on the position of these faults, the structural diameter (Ds) of the caldera is $3.7 \mathrm{~km}$, thus for a structural depth (Ss) of $300 \mathrm{~m}$, the Ss/Ds ratio of 0.08 indicates a mature stage for the caldera evolution. 
Numeric and analog models show that mafic calderas are more favorable to the injection of dikes in circumferential fissures (Corbi et al. , 2016). At Kulo Lasi, traces of the annular reverse faults are given by the narrow and most recent lava flows that occur on the caldera floor close to the base of the caldera wall (Figures 5 and 13). Here, the most recent flows form annular structures parallel to the caldera wall, and we interpret these as having formed in response to recent diking along reverse faults focusing the lavas towards the seafloor. As the black smokers are aligned along these annular structures, it can be deduced that the high-temperature hydrothermal discharge is also most likely controlled by the normal reverse faults. No recent lava flows are emitted at the top or from the base of the resurgent dome. The eruptive fissures are the surface expression of dike emplacement controlled by the state of stress in the volcano (Chadwick and Howard, 1991). This probably explains the situation observed at Kulo Lasi and is in agreement with results of analog experiments (Scandone and Acocella, 2007) where low aspect ratio $(<1.6)$ form a coherent collapse ensuing connection from the chamber to the surface and the creation of continuous ring conduit feeding annular vents. Unlike our observation at Kulo Lasi, active calderas are seldom associated with circumferential eruptive fissures. However, eroded magmatic complexes reveal widespread circumferential dikes (Corbi et al. , 2016). In addition, at Kulo Lasi, no hydrothermal fields are seen at the base of the resurgent dome or on the central part of the caldera floor, indicating that the focus of lava, and thus of heat, at the periphery of the caldera controls the active hydrothermal discharge (Figure 13). All this suggests that at Kulo Lasi, recent diking, recent lava flows, and hydrothermal activity are controlled by the deep reverse faults. In fact, dike Intrusion along the deep ring faults depressurize the reservoir inducing subsidence of the above roof and opening of the faults (Acocella, 2007, Gudmundsson, 2016). This is the case at the Kulo Lasi where the deepest part of the caldera is located in the external part of the caldera floor (Figure 5). The only large cracks observed are also located at the foot of the east wall of the caldera. In addition, topographical observations show that the floor of the caldera has locally subsided near the wall after the emission of the first two generations of recent flows. For example, near the south wall, from where they are emitted, some flows are 5 to $10 \mathrm{~m}$ lower than their distal effusion zone towards the center of the caldera (see flow 3 in figure 5). All these observations testify to a control of the recent volcanic and hydrothermal activities by recent dykes injected in the reverse faults. In addition, this geometry will facilitate the descent of seawater at the outer part of the caldera.

Similar control of the hydrothermal system by injection of a recent dike at the border of the caldera has also been proposed for the Brothers volcano (de Ronde et al. , 2011). However, at the Brothers caldera, there is no morphologically well-defined continuous ring fault wall 
(Embley et al. , 2012). On the Clark volcano, during the caldera stage hydrothermal activity was focused along the caldera ring faults (de Ronde et al. , 2014b).

\subsection{Depth of the reaction zone}

The geometry of the collapsed structure depends strongly on the size and depth of the magma chamber (Cole et al. , 2005, Kusumoto and Takemura, 2005, Roche et al., 2000). According to end-member mechanisms proposed for caldera collapse, the Kulo Lasi has the characteristics of a piston model (Cole et al. , 2005, Lipman, 1997, Roche et al., 2000). This model has a roof aspect ratio $R$ (thickness /width of the magma chamber roof) of $<1.4$ (Roche and Druitt, 2001). The depth of the magma chamber can be estimated from the ratio of the area tectonized by normal faults on the periphery of the caldera (annular extension zone) to the total surface of the caldera (Roche et al. , 2000). For the Kulo Lasi, the extension zone covers $10.04 \mathrm{~km}^{2}(\sim 50 \%)$ of the total surface of the caldera $\left(20.2 \mathrm{~km}^{2}\right)$. According to the model proposed by Roche (Roche et al. , 2000), $50 \%$ of extensional zone corresponds to a roof aspect ratio above the magma chamber (thickness/width) of 0.25 . Considering the maximum width of the caldera $(5.3 \mathrm{~km})$ the depth of the magma chamber before the caldera collapse is thus estimated to be at about $1.3 \mathrm{~km}$.

The resurgent dome is very well defined and surrounded by relatively flat floor. Its slopes are made of fragmented pillow lava. The absence of sediments on the talus indicates that the resurgent dome is a very recent structure. Experimental results show that there is a close correlation between the final shapes of the uplifted area and those of the intrusions (Galland, 2012). The asymmetry of the uprising depends directly on the asymmetry of the intrusion. In addition, the uplifted zones are directly located above the shallow part of the intrusion (Galland, 2012) and the deformation pattern directly reflects the 3D shape of the underlying intrusion. Thus, at Kulo Lasi the position of the resurgent dome in the NW quarter of the caldera floor indicates the shallowest part of the new magma chamber. This is also coherent with the position of the high-temperature vents in the NW part of the caldera. No extrusion of recent lava is observed on the resurgent dome and there is no graben at its top. Only preexisting N25 and N70 faults are reactivated. This can be interpreted as the rise of a rigid block, as described by Acocella for both analog models and field observations (Acocella et al. , 2001). This morphology corresponds to an aspect ratio (depth of the chamber/width of the resurgent block) close to 1 (Acocella et al. , 2001). The diameter of the resurgent dome is $1.6 \mathrm{~km}$, thus for an aspect ratio of 1 , the depth of the new magma chamber should be close to $1.6 \mathrm{~km}$ under the resurgent dome. This indicates that the top of the new magma chamber may be slightly deeper than the magma chamber existing prior to the collapse of the caldera. 
This also promotes the rheological model recently proposed by Galetto (Galetto et al. , 2017) and where the formation of a caldera creates, at the level of the chamber, a transition zone of residual magma. In this model, the viscosity contrast between the residual magma chamber and the newly injected magma underneath provides a rheological barrier that favors the trapping and accumulation of new magma at depth and hinders the propagation upwards of the newly injected magma. This process allows the formation of a resurgent dome and of a large magma chamber (Galetto et al. , 2017). In this configuration, diking and eruptions occur preferentially at the periphery of the system along the deep reverse faults.

Even is andesitic lava are found in the Kulo Lasi caldera, no explosive products are observed. Geochemical and mineral variability in the composition of lava may be used to probe the conditions of magma storage and processes that drive magma evolution of caldera-producing magmatic systems. Geochemical and petrological studies are underway to discuss this issue for the Kulo Lasi volcano and will be published in a specific paper.

\subsection{Type of early alteration}

The Mg enrichment in the altered volcanic rocks probably reflects a loss of magnesium from seawater in the descending part of a convective cell. This magnesium is most likely taken up by chlorite (Mottl, 1983). Mineral assemblages in Desmos and the nearby PacManus hydrothermal systems of the Manus Basin, are interpreted to have formed during advanced argillic alteration by acid-sulfate fluids, and typically contain $\mathrm{Na}$ - and K-bearing alunite, pyrophyllite, silica phases, anhydrite and pyrite, but no Mg-bearing minerals (Gena et al. , 2001, Lackschewitz et al. , 2004, Paulick and Bach, 2006, Seewald et al. , 2015). The same assemblage has been described for the NW Rota-1 volcano in the Mariana arc and for the Brothers volcano (de Ronde et al. , 2005). At Kulo Lasi volcano, the presence of chalcopyrite typically reflects high-temperature hydrothermal alteration $\left(>300^{\circ} \mathrm{C}\right)$, while the pyrrhotite could indicate somewhat more reducing conditions during the early stages of alteration. No specific minerals, indicative of magmatic fluid and acid-sulfate alteration, such as alunite or pyrophyllite, were identified in our samples. Thus, during the first hydrothermal stage at Kulo Lasi, we should consider a classical water/rock type hydrothermal system, with hightemperature fluids and deposition of pyrite and chalcopyrite as disseminated and stockwork mineralization during the fluid ascent. This is similar to the water/rock-dominated system discussed by de Ronde and Stucker (de Ronde and Stucker, 2015) for arc and back-arc volcanoes. 
At Kulo Lasi volcano, the alteration outcrops are found on the caldera walls, with significant alteration and stockwork mineralization near the top of the wall. This indicate that this alteration occurred prior to, or during, the early stages of the caldera formation. The occurrence of extensive alteration also favors a model of a progressive collapse of the caldera rather than a single rapid event as described by Geshi (Geshi et al. , 2002). At Brothers volcano, the distribution of alteration zones and extinct and active chimneys has also been suggested to infer 'progressive' migration of the hydrothermal system as the caldera was formed (de Ronde et al. , 2005, Embley et al. , 2012). A study of Clark volcano has suggested that hydrothermal activity associated with caldera formation can then be superseded by the building of a cone inside the caldera (de Ronde et al., 2014b).

\subsection{Fluid composition}

\subsubsection{Unusual composition of the fluid}

In modern submarine hydrothermal systems, two types of fluids may be present: evolved seawater generated by water/rock-dominated convective systems, and magmatic fluids. During water/rock-dominated hydrothermal circulation, $\mathrm{Mg}$ and $\mathrm{SO}_{4}{ }^{2-}$ from seawater are completely trapped in the altered volcanic rocks, and a pure hydrothermal fluid contains no $\mathrm{Mg}$ or $\mathrm{SO}_{4}{ }^{2-}$ (Seewald et al. , 2015, Von Damm et al. , 1985). Pure hydrothermal endmembers can, therefore, be calculated by extrapolation of the hydrothermal composition to $\mathrm{Mg}=0$ (Von Damm et al. , 1985). The high temperature fluids $\left(>300^{\circ} \mathrm{C}\right)$ from the Kulo Lasi (Table 3) have unusually high concentrations of $\mathrm{Mg}\left(24.6\right.$ to $34.9 \mathrm{mM}$ ) and $\mathrm{SO}_{4}{ }^{2-}$ (6.2 to 12.0 $\mathrm{mM})$. However, the low $\mathrm{pH}(2.24$ to 3.32$)$ and the high temperature $\left(338-343^{\circ} \mathrm{C}\right)$ of these fluids indicate that significant mixing with cold seawater at subsurface or during sampling is rather unlikely (Konn et al. , 2018). Mixing with cold seawater would not maintain the temperature of $343^{\circ} \mathrm{C}$ and the low $\mathrm{pH}$ while increasing the concentration of $\mathrm{Mg}$ from 0 to $\sim 50 \%$ of the seawater concentration.

\subsubsection{Evidence for phase separation}

At their sampled seafloor conditions the Kulo Lasi vent fluids $\left(P=147\right.$ bars and $\left.T=343^{\circ} \mathrm{C}\right)$ are located on the two-phase curve for seawater with low $\mathrm{CO}_{2}$ concentration (Bischoff and Rosenbauer, 1984, Monecke et al. , 2014) and within the field of subcritical boiling. Thus, variations in chlorinity, from $34 \%$ higher to $9 \%$ lower than that of the seawater, can be explained by a process of phase separation (Bischoff and Rosenbauer, 1987). An adiabatic decompression of supercritical seawater (Bischoff and Pitzer, 1989, Foustoukos and Seyfried, 2007a) would cause it to separate, at about 320-350 bars and $415-420^{\circ} \mathrm{C}$ (Konn et al. , 2018) into two phases having the $\mathrm{NaCl}$ percentages observed at Kulo Lasi. 


\subsubsection{Magmatic fluid contribution?}

A possibility to explain high $\mathrm{Mg}$ and $\mathrm{SO}_{4}{ }^{2-}$ concentrations at Kulo Lasi is the contribution of magmatic fluids. Magmatic-hydrothermal systems are thought to make up around $70 \%$ of hydrothermal systems related to arc volcanoes and are also present in back-arcs (de Ronde and Stucker, 2015). In arc and back-arc environments, degassing of $\mathrm{SO}_{2}$ reflects a fundamental difference in the speciation of sulfur in magma. In general, sulfur extracted from volcanic rocks occurs as $\mathrm{H}_{2} \mathrm{~S}$ in water/rock-dominated fluids, whereas magmatic $\mathrm{SO}_{2}$ strongly partitions into aqueous fluids exsolved from magma (Scaillet and Pichavant, 2003). Magmatically-derived $\mathrm{SO}_{2}$ undergoes disproportionation in the upflow zone to produce reduced and oxidized sulfur species upon cooling (Butterfield et al., 2011, de Ronde et al. , 2015, de Ronde et al. , 2005, de Ronde et al. , 2011, Embley et al. , 2006, Gamo et al. , 1997, Herzig et al. , 1998, Resing et al. , 2007, Seewald et al. , 2015) according to the reactions:

(1) $4 \mathrm{SO}_{2(\mathrm{aq})}+4 \mathrm{H}_{2} \mathrm{O}=\mathrm{H}_{2} \mathrm{~S}+6 \mathrm{H}^{+}+3 \mathrm{SO}_{4}^{2-}$

(2) $3 \mathrm{SO}_{2(\text { aq })}+2 \mathrm{H} 2 \mathrm{O}=\mathrm{S}_{(\mathrm{S})}^{0}+4 \mathrm{H}^{+}+2 \mathrm{SO}_{4}^{2}$

(3) $2 \mathrm{H}_{2} \mathrm{~S}+\mathrm{SO}_{2}=2 \mathrm{H}_{2} \mathrm{O}+3 \mathrm{~S}^{0}$

This process contributes to a lowering of $\mathrm{pH}$ and a rise in $\mathrm{SO}_{4}{ }^{2-}$ and $\mathrm{S}^{0}$. Elemental sulfur is the most commonly deposited phase in magmatic-hydrothermal systems and can form lakes of molten sulfur (de Ronde et al. , 2015, de Ronde and Stucker, 2015). These acid-sulfate fluids represent a different style of hydrothermal activity to black smoker fluids at oceanic spreading centers where water/rock-dominated fluid venting is dominant. In particular, the magmatic fluids are more acidic and contain substantially higher aqueous $\mathrm{SO}_{4}{ }^{2-}$ and $\mathrm{Mg}$. They also show similarities to the fluids responsible for high sulfidation epithermal deposits in subaerial settings (Hedenquist and Lowenstern, 1994, Seewald et al. , 2015). For example, at the Desmos and North Su sites in the Manus back-arc basin, where magmatichydrothermal fluids are venting, concentrations of $\mathrm{Mg}$ and $\mathrm{SO}_{4}{ }^{2-}$ are high (Gamo et al. , 1997, Gena et al. , 2006, Seewald et al. , 2015) despite the very low $\mathrm{pH}(\mathrm{pH} \sim 2)$, indicating that magmatic $\mathrm{SO}_{2}$ has mixed with the fluid. The input of magmatic volatiles has also been demonstrated at the NW Rota-1 and Brothers arc volcanoes (Butterfield et al. , 2011, de Ronde et al. , 2011) and in the PacManus field (Yang and Scott, 1996, 2002). High magnesium concentrations in magmatic fluids make it difficult to regress the data through $\mathrm{Mg}$ $=0$ to calculate the end-member hydrothermal fluid concentrations, as is done with water/rock systems. In this situation, sulfate has poor correlation with magnesium, and with $\mathrm{pH}$ due to the disproportionation reaction (equation 2) (Butterfield et al. , 2011, de Ronde et 
al. , 2011, de Ronde and Stucker, 2015, McMurtry et al. , 1993, Seewald et al. , 2015, Stucker et al. , 2017). This is not the case for the Kulo Lasi fluids where the positive correlation, similar to that observed in water-rock systems, between $\mathrm{Mg}$ and $\mathrm{SO}_{4}{ }^{2-}\left(\mathrm{R}^{2}=0.97\right)$ and between $\mathrm{pH}$ and $\mathrm{SO}_{4}{ }^{2-}\left(\mathrm{R}^{2}=0.95\right)$ rather suggests mixing with seawater. Si and Fe/Mn are on a mixing line $\left(R^{2}=0,80\right)$ with seawater, indicating that the silica concentrations correspond to a dilution of hydrothermal fluid with seawater. The low $\mathrm{CO}_{2}$ concentration in the fluid implies completely degassed lava, which has lost the magmatic volatiles $\left(\mathrm{CO}_{2}, \mathrm{SO}_{2}\right)$ during the eruptive phase. Thus, low $\mathrm{CO}_{2}$ and high $\mathrm{H}_{2} \mathrm{~S}$ probably also indicate a low contribution of magmatic fluids because the magmatic degassing is characterized by strong enrichment in $\mathrm{CO}_{2}$ (Butterfield et al. , 2011, de Ronde et al. , 2011, de Ronde and Stucker, 2015, Lupton et al. , 2006, Lupton et al. , 2008, Seewald et al., 2015). At Kulo Lasi, $\mathrm{H}_{2} \mathrm{~S}$ concentrations $(<5 \mathrm{mM})$ are within the range of hydrothermal fluids from water-rockdominated systems on mid-Ocean Ridges and $\mathrm{CH}_{4}(<0.001$ to $0.006 \mathrm{mM})$ concentrations are relatively low. Therefore, we have no evidence of magmatic fluid contribution in the collected fluids.

However, at Kulo Lasi, a magmatic episode is suggested by widespread occurrence, near the active vents, of patches of pure native sulfur (Figure 10G) at the surface of the most recent lava flows. This indicates that the reaction 2 may have been occurring on the seafloor in the past. Native sulfur is absent from the active chimneys dominated by sulfides and anhydrite. In fact, no activity is associated with sulfur deposits. Thus, even if both types of deposits grow on the surface of the same recent lava flows, it appears that the native sulfur deposits formed prior to the sulfide chimneys during an early episode of magmatic fluid venting. Indeed, mineralogical composition of the chimneys is not compatible with highsulfidation fluids. At Kulo Lasi, FeS content in high temperature sphalerite from the core of active chimneys (average FeS: 29.5 mol\%) and in inactive chimneys (9.6\% FeS on the NW field and $16.2 \%$ in the Eastern field) point to a low sulfidation state (Evans et al. , 2017) with pyrrhotite and isocubanite as the stable sulfide phases. The occurrence of pyrrhotite implies relatively reducing conditions that are not compatible with the presence of $\mathrm{SO}_{4}{ }^{2-}$ of magmatic origin in the fluid. The high $\mathrm{H}_{2}$ concentrations recorded in all collected fluids ( 1 to $19.8 \mathrm{mM}$ ) could explain the precipitation of low- $\mathrm{fO}_{2}-\mathrm{fS}_{2}$ mineral assemblages. In recent study, (Kawasumi and Chiba, 2017) conclude that $\mathrm{H}_{2}$ concentrations strongly control the $\mathrm{fS}_{2}$ of hydrothermal fluids and that dissolved $\mathrm{H}_{2}$ concentrations of over $1 \mathrm{~mm} / \mathrm{kg}$ result in the low $\mathrm{fO}_{2}$ and $\mathrm{fS}_{2}$ necessary for pyrrhotite to be stable. The replacement of pyrrhotite by pyrite in some chimneys (Figure $15 \mathrm{H}$ ) might also reflect rapid changes in the $\mathrm{H}_{2} \mathrm{~S}$ and/or $\mathrm{H}_{2}$ concentration in the fluid. In addition, minerals characteristic of high sulfidation magmatic fluids, such as alunite and enargite, are not found at Kulo Lasi. 
In general, magmatic-hydrothermal systems contain very little $\mathrm{Li}$ (de Ronde and Stucker, 2015) $(<100 \mu \mathrm{M})$ while the water/rock-dominated fluids have high Li concentrations ( $>500$ $\mu \mathrm{M}$ ). At Kulo Lasi, the concentrations of mobile elements such as Li (266 to $519 \mu \mathrm{M}$ in the end-member fluid) and $\mathrm{Rb}$ (44 to $95 \mu \mathrm{M}$ in the end-member fluid) also point to water/rockdominated fluids and indicate interaction with fresh volcanic rocks under conditions with low water/rock ratios (Seewald et al. , 2015, Seyfried, 1987, Von Damm, 1995). The slightly positive sulfur isotope signature (between 1.3 and $3.5 \%$ ) measured in sulfides from the chimneys is typical of many oceanic sulfide mineralization and suggests no contribution of magmatic $\mathrm{SO}_{2}\left(\delta^{34} \mathrm{~S}<0 \%\right.$ o).

Thus, the combination of low $\mathrm{CO}_{2}$, the presence of $\mathrm{H}_{2} \mathrm{~S}$ in the fluid, the positive sulfur isotopic values in sulfides, the high $\mathrm{H}_{2}$ concentration in the fluid and the low-sulfidation characteristics of mineral assemblages are not compatible with a major contribution of magmatic fluid at the time of sampling the fluids.

\subsubsection{Rapid evolution of the system}

The low $\mathrm{CH}_{4}$ concentration in the fluids collected in 2010 cannot account for the elevated concentration of $\mathrm{CH}_{4}$ in the plume existing above the caldera at the same time. The strong difference in the $\mathrm{CH}_{4} / \mathrm{Mn}$ ratios between the plume (0.7 - 4.5) (Konn et al. , 2016) and the sampled fluids $(0.001-0.01)$ (Konn et al. , 2018) also indicate that the methane plume in 2010 is not generated by the hot fluids venting in 2010. In addition, the elevated $\mathrm{CH}_{4}$ levels in the plume had vanished in 2011 . This is most likely caused by a recent eruptive event (Konn et al. , 2016) followed by the new venting of fluids with low $\mathrm{CH}_{4}$ concentration. The observation of very small chimneys, without fixed animals, growing on top of the most recent lava flows also indicate the beginning of a new hydrothermal episode after a major eruptive event. A rapid decrease in the $\mathrm{CH}_{4}$ output after the eruptive event was also observed in the Endeavour segment (Lilley et al. , 2003). We thus consider that a $\mathrm{CH}_{4}$-poor plume, generated by the new hydrothermal episode following the eruptive event, replaces the $\mathrm{CH}_{4}$-rich plume, accumulated prior to the volcanic eruption. This rapid change suggests that the diking episode feeding the most recent lava flows occurred less than one year before sampling of the fluids in 2010. Unfortunately, due to bad weather conditions, time series sampling of the fluid was not possible in 2012.

\subsubsection{High concentration of hydrogen}

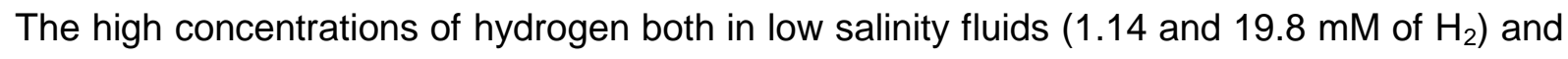
in high salinity fluids ( 1.04 and $6.18 \mathrm{mM}$ of $\mathrm{H}_{2}$ ) is unusual. Hydrogen is generally lower than 
$0.5 \mathrm{mM}$ in most oceanic hydrothermal fields generated by water/rock reactions. In deep-sea volcanic environments, the highest $\mathrm{H}_{2}$ enrichment (8 to $26 \mathrm{mM}$ ) in hydrothermal fluids is in ultramafic environments where hydrogen is generated during serpentinization (Charlou et al. , 2010). As there is no evidence for shallow mantle outcrops at Kulo Lasi, this process cannot be considered here.

A potential source of $\mathrm{H}_{2}$ is a primary magmatic gas released through magma degassing. However, lavas in arc environments are more oxidizing than at mid-ocean ridges and point to low $\mathrm{H}_{2}$ released from the magma (Holloway and Blank, 1994). For this reason, fluid collected from submarine magmatic-hydrothermal systems, such as the Brother Volcano, have a low $\mathrm{H}_{2}$ concentration (maximum $67.7 \mu \mathrm{M}$ ) (de Ronde et al. , 2011). In the same way, plumes generated by acid-sulfate fluids in arc environments at Monowai volcano (Leybourne et al. , 2012b) and Rota-1 volcano (Resing et al. , 2007) are not enriched in $\mathrm{H}_{2}$ compared to plumes related to eruptive events.

A possible explanation for the high levels of $\mathrm{H}_{2}$ at Kulo Lasi is the reaction of seawater with hot lava according to the reaction (Holloway, 2004):

(4) $3 \mathrm{FeO}$ (magma) $+\mathrm{H}_{2} \mathrm{O}=\mathrm{Fe}_{3} \mathrm{O}_{4}$ (magnetite) $+\mathrm{H}_{2}$ (fluid)

Indeed, hydrogen can be temporarily concentrated in fluids during eruptive events and episodes of diking on ocean ridges. $\mathrm{H}_{2}$ is produced by the oxidation of $\mathrm{Fe}$ (II) to $\mathrm{Fe}$ (III) during high-temperature reactions of seawater with lava. The oxygen necessary for this oxidation is derived from the seawater (Berndt et al. , 1996, Christie et al. , 1986, McCollom and Seewald, 2007). Experimental studies have shown that fluids that have reacted with orthopyroxene achieved the highest dissolved $\mathrm{H}_{2}$ concentration (Allen and Seyfried, 2003).

At Kilauea, large quantities of $\mathrm{H}_{2}$ (up to $2 \mu \mathrm{M}$ ) are generated when lava flows interact with seawater (Sansone and Resing, 1995, Sansone et al. , 1991). At $9^{\circ} 46^{\prime} \mathrm{N}$ on the East Pacific Rise (EPR), hydrogen concentrations in the fluid were up to $40.2 \mathrm{mM}$ two weeks after the emplacement of a new dyke (Lilley et al. , 2003) and returned to normal low concentrations $(<0.5 \mathrm{mM})$ less than a year after the dike injection. Similar observations were made in the Endeavour segment of the Juan de Fuca Ridge, where hydrogen concentration in the fluid was up to $1.31 \mathrm{mM}$ four months after a diking event and returned to normal values one year later (Lilley et al. , 2003). At $18^{\circ} 26 \mathrm{~S}$ on the EPR high concentration of $\mathrm{H}_{2}(1.3 \mathrm{mM}$ ) are reported in fluids venting on extremely recent lobate flows (Charlou et al. , 1996). In back-arc 
basins, $\mathrm{H}_{2}$ is also enriched in fluids generated during eruptive events at W-Mata (16.6 mM $\mathrm{H}_{2}$ ) and NW Rota-1 (2.2 $\mathrm{mM} \mathrm{H}_{2}$ ).

Immediately following eruptive events, high $\mathrm{H}_{2}$ concentrations are also reported in the plumes from Gorda Ridge (47 nM) (Kelley et al. , 1998), Loihi volcano (20 nM) (Sansone et al. , 1996) (Sansone and Resing, 1995) and axial volcano (183 nM) (McLaughlin-West et al. , 1999). High $\mathrm{H}_{2}$ concentration is also found in the plumes sampled during the eruptive events at West Mata (up to 15,9 nM) (Baumberger et al. , 2014) and on the NELSC $(9,1 \mathrm{nM}$ ) (Baker et al. , 2011). Thus, $\mathrm{H}_{2}$ detection in plumes is now considered a clear evidence of extremely recent or ongoing eruption.

Similarly, at Kulo Lasi, based on field observation and fluid chemistry, we suggest that high $\mathrm{H}_{2}$ concentration in the fluid is generated when seawater is heated in contact with the still-hot dykes recently injected at the periphery of the caldera. In addition, the fluids associated with the eruptive events at $9-10^{\circ} \mathrm{N}$ on the EPR (Von Damm, 2000) have a low pH (between 2 and 3) and condensed gases produced during the interaction between molten rocks and seawater in Hawaii also have low pH (1.1 to 2.1) (Resing and Sansone, 1999, 2002). The low $\mathrm{pH}$ may also be explained by subsurface deposition of $\mathrm{Cu}$ and Fe sulfides. Petrographic and geochemical data for the sulfide deposits clearly supports formation from reduced fluids (pyrrhotite), and the presence of significant silica, low $\mathrm{Cu}$, and abundant $\mathrm{Zn}$ suggests moderate to high fluid $\mathrm{pH}$ (Evans et al. , 2017). Loss of sulfate and calcium from subsurface deposition of anhydrite can also occur.

As a result, the fluid is hot, enriched in $\mathrm{H}_{2}$, and may have a low $\mathrm{pH}$. Thus, fluids from the Kulo Lasi may be considered as the mixing of a deep hydrothermal fluid of the water/rock type with seawater heated on contact with the hot dykes. This process can explain high temperature and high concentrations of $\mathrm{SO}_{4}{ }^{2-}$ and $\mathrm{Mg}$ in the mixed fluid. As the contact of cold seawater with the dike at a shallow level is probably of short duration, the composition of the seawater is preserved (Table 3 ). Considering the mixing of heated seawater ( $\mathrm{Mg}=53.2$ $\mathrm{mM}$ ) with an evolved water/rock type fluid $(\mathrm{Mg}=0)$ we can calculate the maximum percentage of mixing and the end-member compositions for the high temperature collected fluid (Tab 4).

\subsubsection{Silica and Fe/Mn geothermometer and geobarometer}

As there is no $\mathrm{Fe}$ and $\mathrm{Mn}$ in the seawater, the Fe/Mn ratio is preserved during subsurface mixing with the heated seawater. Using the Fe/Mn geothermometer (Pester et al. , 2011), temperatures in the reaction zone are estimated to be $415^{\circ} \mathrm{C}$ and $414^{\circ} \mathrm{C}$ for the low salinity 
fluids and $426^{\circ} \mathrm{C}$ and $422^{\circ} \mathrm{C}$ for the high salinity fluids (Table 3 ). Using these maximum temperatures and the measured temperature in the sampled fluid (considered a mixture of an end-member of water/rock type fluid with various amounts of heated seawater) we have calculated the minimum temperature of the heated seawater. This temperature is close to $250^{\circ} \mathrm{C}$ both for the high and low salinity fluids (Table 3 ). This probably indicates that both types of fluids have mixed with the same heated seawater. If we consider some cooling during the ascent of the deep fluid, the end-member temperature used for our calculation may be lower, and the temperature of the heated seawater could be closer to $300^{\circ} \mathrm{C}$. The $\mathrm{Fe} / \mathrm{Mn}$ temperatures can also be used in conjunction with dissolved $\mathrm{Si}$ and $\mathrm{Cl}$ to constrain possible subseafloor reaction conditions in the pressure-temperature space (Bischoff and Rosenbauer, 1985, Fontaine et al. , 2009, Foustoukos and Seyfried, 2007b, Pester et al. , 2012, Pester et al. , 2011).

The silica isopleths can be used as a pressure proxy when they coincide with the associated temperature calculated using the Fe/Mn ratio (Seewald and Seyfried, 1990). For low salinity fluids, assuming quartz-fluid equilibrium, we can estimate the Si concentration and pressure condition for the formation of end-member fluids using the diagram of chlorinity and silica isoconcentration lines in the P-T space proposed by Fontaine (Fontaine et al. , 2009) (Figure 17 ) and the $\mathrm{Cl}-\mathrm{SiO}_{2}$ diagram of Foustoukos (Foustoukos and Seyfried, 2007b). Considering the temperature of the reaction zone estimated by the $\mathrm{Fe} / \mathrm{Mn}$ geothermometer $\left(415^{\circ} \mathrm{C}\right.$ for the low salinity fluid) and the chlorinity of the end-member (average $0.464 \mathrm{mM}$ for the low salinity fluid) a pressure of 315 bars and silica concentration of about $8.5 \mathrm{mM}$ are estimated for the end-member fluid in the reaction zone (Figure 17). Using the percentage of mixing with seawater calculated with $\mathrm{Mg}$ (Table 3), the calculated Si concentration in the end-member fluid implies that the heated seawater is enriched in silica at a concentration estimated to be around $8.1 \mathrm{mM}$. Indeed, during the lava seawater reactions, the fluids may be enriched in silica (Resing and Sansone, 2002).

Thus, we can propose that the Kulo Lasi fluids have equilibrated at a temperature between $415^{\circ} \mathrm{C}$ (low salinity) and $425^{\circ} \mathrm{C}$ (high salinity fluid) and at a pressure of about 315 bars. This indicates equilibrium of $\mathrm{Si}, \mathrm{Fe}$, and $\mathrm{Mn}$ at about $1650 \mathrm{~m}$ below the seafloor. For condensed vapor phases that rise more rapidly than brines, these conditions are considered close to those at the reaction zone near the upper limit of the magma chamber (Fontaine et al. , 2009). These values are consistent with the depth of the new magma chamber under the resurgent dome, estimated to be at $1600 \mathrm{~m}$ below the seafloor, using the roof aspect ratio (see discussion above). 
In summary, our results suggest a rapidly evolving system, with an early episode of magmatic fluid enriched in $\mathrm{SO}_{2}$ and characterized by sulfur deposits at the surface of the flows just after the last eruption. This episode is quickly followed by the emission of fluids, resulting from the mixing of deep fluids of water/rock reactions type with heated seawater and without evidence of magmatic contribution. The rapid change in composition suggests a young, immature, and unstable hydrothermal system related to the recent volcanic episode. This instability has been observed in other areas of recent magmatic events on the EPR (Lilley et al. , 2003) and in the back-arc and arcs (Baumberger et al. , 2014, Butterfield et al. , 2011). Considering the rapid decrease in the hydrogen concentration of fluids on the EPR and Juan de Fuca Ridge after an eruptive event, the high concentrations of $\mathrm{H}_{2}$ in Kulo Lasi fluids probably reflect an eruptive episode that occurred only a few months before the sampling of the fluids. This is coherent with the evolution of the $\mathrm{CH}_{4}$ concentration in the plume discussed earlier in this paper.

\subsection{Atypical composition of hydrothermal mineralization for a back-arc setting}

The mineralization at Kulo Lasi appears to be relatively atypical compared to known sulfide mineralization in arc and back-arc basin environments, where the dominant iron sulfide is pyrite, and the dominant copper sulfide is chalcopyrite. This is the case for the Brothers volcano caldera (Berkenbosch et al. , 2012, de Ronde et al. , 2005, de Ronde et al. , 2011), the Sunrise site at the Myojin Knoll (Fiske et al. , 2001, Glasby et al. , 2008), Palinuro (Petersen et al. , 2014), the volcano 19 caldera (Stoffers et al. , 2006) and the East Diamante (Hein et al. , 2014). Pyrite is also the dominant iron sulfide in the Okinawa basin (Halbach and Pracejus, 1993), Lau Basin (Fouquet et al. , 1993, Herzig et al. , 1998) and Manus Basins (Binns and Scott, 1993).

In general, mineralization in back-arc basins sites are typically dominated by pyrite, which is indicative of relatively oxidizing hydrothermal fluids The occurrence of pyrrhotite/isocubanite as the dominant sulfides at Kulo Lasi is rarely reported in a back-arc environments. Pyrrhotite has previously been found in trace amounts in chimneys on Brothers volcano (Berkenbosch et al. , 2012). Pyrrhotite and isocubanite (cubic cubanite) were recently described in chimneys from the Kilo Moana vent field in the Lau Basin (Evans et al. , 2017, Tivey et al. , 2012). Pyrrhotite and isocubanite are indicative of more reducing conditions than pyrite and chalcopyrite. These conditions are probably explained by the high $\mathrm{H}_{2}$ concentration in the fluids (Table 3). The presence of significant amounts of galena and barite are typical of arc and back-arc mineralization. While the dominant sulfides are pyrrhotite and isocubanite, 
replacement of pyrrhotite by pyrite is observed (Figure 13H). This indicates that the more reduced phases may be replaced by much more oxidized phases. This is compatible with the $\mathrm{SO}_{4}{ }^{2-}$ enrichment in the fluids. As this is occurring in young chimneys, we suggest that there has been a rapid change in the fluid chemistry, from highly reducing fluids to the more oxidizing fluid due to instabilities in mixing between the reduced hydrothermal fluid and heated seawater. This can also be due to rapid change in the $\mathrm{H}_{2}$ content of the fluid. The instability of the Kulo Lasi vents was also seen in the plume studies, which showed dramatic changes over a one-year period (Konn et al. , 2016).

From a geochemical point of view, the Kulo Lasi mineralisation has relatively low levels of copper $(0.8 w t \%)$, perhaps due to subsurface precipitates, and is relatively rich in zinc $(\approx 6$ $w t \%)$. Lead $(\approx 0.3 \mathrm{wt} \%)$ and barium $(1 \%)$ are similar to other back-arc basin (BAB) mineralization in the SW Pacific (Table 5). In the $\mathrm{Cu}-\mathrm{Zn}$-Pb triangular diagram (Fouquet et al. , 1993) (Figure 18), the Kulo Lasi mineralization plots in the field of back-arc basins mineralization associated with basaltic and felsic host rocks. This contrast with mature backarc with MORB-type lavas (i.e; North Fiji basin) for which the mineralization, depleted in $\mathrm{Pb}$, plots in the field of mid ocean ridges mineralisation.

High concentrations of certain trace elements appear to be directly related to the presence of particular mineral phases. For example, the positive correlation between $\mathrm{Pb}$ and $\mathrm{Zn}$ is consistent with petrographic observations of inclusions of galena in sphalerite. The abundance of sphalerite also controls the enrichment in $\mathrm{Cd}, \mathrm{Sn}$, and $\mathrm{Ag}$. Similarly, the positive correlations between cobalt, selenium, and iron indicate an affinity between these elements and pyrrhotite. Variations in the gallium and germanium contents are more complicated to interpret though high levels appear to correspond to sphalerite-rich samples.

Regarding the minor elements, Ga (> 100 ppm) is unusually high. Compared to back-arc mineralization, the Kulo Lasi sulfides are enriched in Co ( $\approx 0.15 \mathrm{wt} \%)$, Sn (168 ppm) and especially in Se (> $350 \mathrm{ppm}$ ) (Table 5). Cobalt and selenium enrichments are commonly associated with MORs mineralization. The highest known average concentrations in Co (5086 ppm), in Sn (347 ppm) and in Se (772 ppm) are in mineralization found on slow spreading ridges in ultramafic rocks environments (Evrard et al. , 2015, Fouquet et al. , 2010). Like the Kulo Lasi mineralization, these ultramafic mineralization are characterized by an abundance of isocubanite and pyrrhotite and reducing conditions that may favor the concentration of Co and Se. As expected for a pyrrhotite-dominant mineralization, gold is not enriched (Hannington and Scott, 1989). 
Thus, the Kulo Lasi mineralization has chemical affinities with both back-arc and ocean-ridge mineralization. All of these geochemical features indicate a complex signature that reflects characteristics of both immature felsic back-arc basins (I.e., Lau basin) and mature basaltic back-arc basins (i.e., North Fiji basin). In the North Fiji Basin, for example, Se and Co are also enriched (Table 5). This is also coherent with the volcanic rock composition, which indicates that the magmatic activity in the Kulo Lasi region is not directly related to subduction. Thus, the Kulo Lasi mineralization is atypical and differs from mineralization associated with arc and back-arcs located closer to the subduction zone.

\subsection{Timing and control of the different types of mineralization in large basaltic submarine calderas based on Kulo Lasi volcano}

The large amount and diversity of hydrothermal mineralization at Kulo Lasi allows for discussion of the evolution of different types of mineralization in relation to caldera formation, history, and geometry. Based on high-resolution mapping, field observations, vent fluid compositions, and types of hydrothermal mineralization, we propose a four-stage model for evolution of the caldera and formation of mineralization in deep-sea basaltic/andesitic calderas. This model is also based on recent advances in the understanding of the formation of aerial and submarine calderas.

\subsubsection{Stage 1: Early stage of caldera formation}

During Stage1, the volcano is built by a series of lava flows that pour from the summit (Figure 19). The basement of the volcano is made up of recent tectonized lava. Early Fe/Mn mineralization associated with low-temperature diffuse venting precipitate at the top of the volcano. At the end of this construction stage, the magma chamber empties and its summit starts to collapse. This collapse is not a catastrophic event, as observed in large silicic volcanoes (Geshi et al. , 2002), but is instead a slow process that take place over a long period. Cracks and ring fissures, precursors to the formation of the caldera, appear in the summit area. When the deep reverse faults are initialized, the resulting increased permeability allows access to hot hydrothermal fluids from deep within the system. The deep hot fluids can rise to the seafloor along reverse faults and associated fissures that formed prior to the major collapse of the caldera. Evidence for this episode is provided by external normal faults that have exposed outcrops of highly altered zones impregnated with sulfides and associated with stockwork mineralization. The presence of Cu sulfides suggests flows of high-temperature fluids towards the summit of the caldera along the initial faults, while the 
absence of alunite suggests a lack of significant acid-sulfate-like magmatic fluids. The positive value of the sulfur isotopes also indicates a lack of magmatic fluids, which would typically lead to negative values (de Ronde et al. , 2005, de Ronde et al. , 2011, Herzig et al. , 1998). In addition, the high values of $\delta S_{34}$ (6 to 9 per mil) in disseminated pyrites in the alteration zones indicate a seawater contribution to the subsurface hydrothermal fluid. Hightemperature sulfide chimneys should be able to form at the summit of the volcano during this stage, although this has not yet been observed as the dives so far conducted have all been focused on the inside of the caldera. A possibility is that these chimneys were destroyed during the collapse of the caldera. In summary, this stage is characterized by a classic water/rock-dominated convective hydrothermal system, mixed with cold seawater, with no evidence for significant contributions from magmatic fluids.

\subsubsection{Stage 2: Caldera formation}

Stage 2 corresponds to the collapse of the roof of the magma chamber (Figure 20). The formation of the caldera starts with collapse along the internal reverse faults, and then along the normal external faults, forming the morphology now visible on the seafloor. Lava flows are tilted toward the center of the caldera, and talus and scree piles form at the base of the walls. The collapse movements along the outer normal faults result in exhumation of the altered zones and stockwork formed during Stage 1. Freshly broken rocks and new external faults are highly permeable and facilitate the downward penetration of cold seawater. This, combined with the deepening, emptying, and then collapse and cooling of the magma chamber leads to the hydrothermal circulation of low-temperature fluids particularly at the end of the caldera formation. At Kulo Lasi, some areas of silica-rich metalliferous sediments covered by pelagic sediments, located on the caldera floor near the base of the walls, formed during this low-temperature episode.

\subsubsection{Stage 3: New volcanic episode}

This stage begins by refilling of the magma chamber causing its top to swell (Figure 21). The visible consequence is a rising of the caldera floor and the formation of a central resurgent dome from uplift and deformation of the old lava. Several successive lava flows are issued from the base of the caldera walls at the level of the reverse faults emplacement. Scree on the lower slopes of the caldera is consumed by the recent lava flows. Sedimentary formations of low temperature hydrothermal silica and iron oxides are locally precipitated on the early flows at the outer margins of the caldera floor as part of this new volcanic episode. It appears that the final hydrothermal episode of Stage 2 and the earliest hydrothermal episode of Stage 3 are characterized by low temperature hydrothermal emissions on the caldera floor. At Kulo Lasi, none of these sites is active as indicated by the cover of pelagic 
sediments. These hydrothermal mineralization are thought to have been formed by shallow hydrothermal circulation in the highly permeable zones along the outer normal faults. The last lava flows, controlled by the deep reverse fault, probably erupted less than one year ago. At the surface of these recent flows and close to the reverse faults, numerous small deposits of native sulfur are formed by the discharge of magmatic-dominated fluids just after the last eruptive event. This episode was probably very short, less than a few months after the eruptive event.

\subsubsection{Stage 4: High temperature black smoker activity}

Hydrothermal fluids, resulting from water-rock reaction in a deep reaction zone, discharges on the seafloor. Seawater heated $\left(>250^{\circ} \mathrm{C}\right)$ by the still hot dikes mixes with the deep hydrothermal fluid near the surface (Figure 22). Reactions of fluids with the hot dike also result in hydrogen enrichment. On the western side of Kulo Lasi caldera, the alignment of active vents on narrow lava flows is interpreted as a control of both, lava diking and fluid discharge, by the reverse faults. Consequently, black smokers and sulfide deposits occur preferentially on the caldera floor near the base of the walls. This geometry is demonstrated in analog models, and high-temperature discharge has also been documented for other submarine caldera volcanoes near the intersection of the caldera walls and floor (e.g., (Baker et al. , 1999, de Ronde et al. , 2011). On the eastern side of the caldera, weakly active sulfide chimneys are located near large cracks that indicate tectonic extension, facilitating the discharge, near the base of the caldera walls. No chimneys are observed on new flows in the center of the caldera. Low temperature silicic chimneys are active at the base of the caldera walls and diffuse very low temperature venting occurs on the caldera walls. Both types probably result from mixing of hydrothermal fluids with various amounts of cold seawater. Positive sulfur isotopes values and dominant pyrrhotite and isocubanite indicate low sulfidation fluids of water-rock type without magmatic fluid contribution during this stage. Late replacement of pyrrhotite by pyrite and rapid variation in the plume chemistry indicate an unstable hydrothermal system.

\section{Acknowledgements}

The 2010 exploration of the French EEZ of Wallis and Futuna during which the Kulo Lasi volcano was discovered was financed through a public/private consortium comprising the French state, Ifremer, AAMP, and BRGM and industrial groups including Eramet, Technip, and Areva. Eramet; Technip and Ifremer funded the 2012 expedition. We also thank the captains and crew of L'Atalante and Nautile and AUV operation teams for successful highly 
technical cruises. We also thank Cornel De Ronde, Meg Tivey and Sven Petersen and one anonymous reviewer for detailed and constructive reviews of the manuscript. 


\section{Figure captions}

Figure 1: Regional location of the Wallis and Futuna volcanic areas. The white box shows the position of figure 2. E-W black line = North Fiji transform fault. Location of spreading centers and faults are from Pelletier 1996 and 2001 (Pelletier and Auzende, 1996 , Pelletier et al. , 2001).

Figure 2: Bathymetric (left) and seafloor backscatter amplitude (right) maps of the Kulo Lasi volcanic area with $25 \mathrm{~m}$ and $10 \mathrm{~m}$ resolution, respectively. Light gray= old areas covered with sediments. Dark gray = recent volcanic zones. Kulo Lasi volcano is the most recent volcanic structure in the area. See white box in Figure 1 for regional setting.

Figure 3: 3D bathymetric view of Kulo Lasi volcano with a $10 \mathrm{~m}$ resolution derived from the shipborne multibeam surveys at low speed (looking north). To the north of the volcano is a highly tectonized area probably similar to the older area underlying the volcano. The Kulo Lasi volcano itself is relatively non-tectonized compared to the surrounding volcanic basement, except an old tectonized volcanic construction on its NW flank. Note the three flattopped satellite cones near the summit of the volcano. Water depth: red color $=1200 \mathrm{~m}$ to $1500 \mathrm{~m}$; green color $=1500 \mathrm{~m}$ to $1800 \mathrm{~m}$; blue-color $1800 \mathrm{~m}$ to $2300 \mathrm{~m}$.

Figure 4: High-resolution (1 m) AUV-derived 3D bathymetric map of the Kulo Lasi caldera with no vertical exaggeration. Note the collapsed and tilted old lava flows on the left side. The resurgent dome in the center is composed of old tectonized pillow lava flows. The relatively flat caldera floor is made up of several generations of 1-2 $\mathrm{m}$ thick recent flows. The most recent lava flows are clearly visible. Note the abundance of scree along the eastern caldera wall. View looking north from the top of the southern wall of the caldera. Dashed white line shows the position of figure 5 .

Figure 5: High-resolution (1 m pixel grid) bathymetric AUV-derived map showing recent lava flows in the southeast of the caldera. See position on figure 4 . White numbers refer to five successive eruptive episodes: Episode 1- Pillow lava with light sediment coverage (> $1500 \mathrm{~m}$ of water depth). Episode 2- (Purple contours and arrows), scoriaceous lava flows, and sheet flows. Episode 3- (Blue contours and arrows) sheet flows issued from the southern caldera wall. Episode 4- (Yellow contours and arrows), fresh pillow lava without sediment coverage (1490 to $1470 \mathrm{~m}$ of water depth). Episode 5- (Green dashed lines and white arrows). 
Discontinuous and narrow lava flows parallel and close to $(\sim 100 \mathrm{~m})$ the base of the caldera walls. These probably represent the trace of dikes rooted in the reverse faults. For episodes, 2, 3 and 4 the color arrows give the direction of the flow.

Figure 6: TAS (Total Akali-versus-Silica) diagram (Le Bas et al. , 1986). The red circles represent samples of the older lava taken from the caldera walls, and the blue circles represent samples taken from the most recent lava flows. The dashed line approximately separates alkaline volcanic rocks from their subalkaline counterparts.

Figure 7: Selected major elements (in wt\%) plotted against total silica content for the volcanic rocks of the Kulo Lasi. Same symbols as in Figure 6. The red circles represent samples of the older lava taken from the caldera walls, and the blue circles represent samples taken from the most recent lava flows.

Figure 8: Chondrite-normalized rare earth element patterns of Group 1 (Old lava - red lines) and Group 2 (Young lava - blue lines). Chondrite composition from Anders and Grevesse (Anders and Grevesse, 1989). These patterns are very similar and likely derive from the same source.

Figure 9: Locations of the different types of mineralization in the Kulo Lasi caldera superimposed in the high-resolution bathymetric map derived from AUV surveys (1 $\mathrm{m}$ pixel grid). The different diving tracks are also indicated.

Figure 10: Different types of hydrothermal mineralization observed in the Kulo Lasi caldera (see figure 9). A: Fe-Mn mineralization at the top of the north caldera wall. B: Fe-Si hydrothermal sediments on the SW caldera floor. C: Active silica chimneys $\left(43^{\circ} \mathrm{C}\right)$ near the base of the caldera wall. D: Tubeworms and crabs in an area of diffuse venting on the southern caldera wall. E: Inactive sulfide chimney near a large crack in a prismatic lava flow at the base of the SE caldera wall. $\mathrm{F}$ and $\mathrm{H}$ : Active black smokers (up to $343^{\circ} \mathrm{C}$ ) and iron oxide staining on the surface of a recent lava flow. G: Native sulfur (white) at the surface of a recent lava flow. $\mathrm{H}$ : Surface of a recent lava flow. Photos taken from Nautile, each view cover a surface of about 5 to $20 \mathrm{~m}^{2}$.

Figure 11: Detailed AUV-derived bathymetry (left) and seafloor backscatter amplitude maps (right) of the southern wall of the Kulo Lasi caldera, with a resolution of $2 \mathrm{~m}$ and $0.5 \mathrm{~m}$, respectively. Red and yellow lines = dive tracks. Altered zones near the top of the caldera 
wall are outlined in black. The upper section of the caldera is composed of prismatic lava flows. (See figure 9 for location).

Figure 12: High resolution AUV-derived seafloor backscatter map (0.5 m pixel grid). Lowtemperature Si-Fe hydrothermal sediments (light gray patches indicated by arrows) on the caldera floor. Several of the patches were visited during the dives. See figure 9 for location.

Figure 13: Location of mineralization and high temperature hydrothermal activity in the NW sector of the caldera. Left: Bathymetric map and main hydrothermal fields. Right: Geological map showing the different types of lava flows and areas of intensive hydrothermal alteration near the base of the caldera wall. Contours based on dive observations, high-resolution bathymetry and interpretation of seafloor backscatter Images acquired with the AUV Aster ${ }^{X}$. Positions and samples numbers of fluids and chimneys collected during the dives is shown. See figure 9 for location.

Figure 14: Micro-photographic plate - reflected light. A: massive pyrrhotite - the red box corresponds to photo B. B: Overgrowth of isocubanite and sphalerite mantling pyrrhotite. C: Inclusions of pyrite and relics of a former aggregate of sphalerite in pyrrhotite. D: Aggregates of sphalerite with galena inclusions. E: Aggregate of sphalerite with two successive textures: a collomform texture at the center with inclusions of galena $(G)$ and a crystallized texture edge associated with inclusions of isocubanite and late galena - the red dotted line marks the boundary between the two textural forms. F and G: "Inclusions" of isocubanite and chalcopyrite in sphalerite. In Photograph $G$ the chalcopyrite is aligned along the crystallization boundary. H. Pyrrhotite, sphalerite, and isocubanite with chalcopyrite exsolutions.

Figure 15: Micro-photographic plate -reflected light. A, B, and C: Association of sphalerite, isocubanite, pyrrhotite, and pyrite. B and C: Late opal mantles other minerals and may gradually replace sphalerite. D: Replacement of pyrrhotite by a pyrite-sphalerite assemblage. E: Chimney dominated by pyrite and marcasite. The center is enriched in chalcopyrite. F: Ghosts of early pyrrhotite crystals in a pyritic chimney. G. Pyrrhotite that has been strongly altered and partially replaced by pyrite. H: Active chimney. Pyrrhotite blades partially replaced by pyrite.

Figure 16: A-B: Macroscopic samples of altered basalts with disseminated sulfides. Inset: images $=$ polished sections enlarged in C, D, E and F. C-F: Micro-photographs taken under reflected light (showing $(C)$ pyrites dispersed in a strongly altered basaltic matrix, and (D) 
isolated chalcopyrite grains and (E) inclusion of chalcopyrite in pyrite. The presence of chalcopyrite suggests hydrothermal alteration at high-temperature $\left(>300^{\circ} \mathrm{C}\right)$. F: Pyrrhotite inclusions in pyrite.

Figure 17: Chlorinity (in molal, blue lines) and silica (in mmolal, red lines) iso-concentration lines in P-T space (redrawn after Fontaine et al. 2009). The intersection of iso- $\mathrm{Cl}$ and iso-Si defines a single P-T equilibration point. The black circle indicates the estimated equilibration point for vapor-like fluids of the Kulo Lasi field. The position of the Kulo Lasi fluids is determined by the means of temperatures calculated using the Fe/Mn geothermometer $\left(415^{\circ} \mathrm{C}\right)$ (Pester et al. , 2011) and the chlorinity of the end-member low salinity fluid (average $0.464 \mathrm{mM}$ ). This position suggests that, for mineral-fluid equilibrium, the fluid had to reach a pressure of 415 bar. Under these conditions, the silica concentration would be $8.5 \mathrm{mM}$. These conditions are very close to the two-phase boundary and to the critical point of seawater and suggest a reaction zone at a depth of about $1650 \mathrm{~m}$ below the seafloor.

Figure 18: Ternary diagrams showing the composition of the sulfide chimneys from Kulo Lasi., The Pb-Zn-Cu diagram (left) highlights an affinity of Kulo Lasi with mineralization in back-arc basins,(Fouquet et al. , 1993). The Co-Cu-Se diagram (right) highlights an affinity with deposits located in the Mid-Ocean ridges (Fouquet et al. , 2010). (See table 5 for detailed compositions and references).

Figure 19: Stage 1 - End of the main volcanic episode and initiation of collapse. A: recent lava flows forming the shield volcano. B: fractured volcanic basement. M: magma chamber. Initiation of faulting at the top of the volcano: Red dashed line = reverse faults; Dark blue dashed lines $=$ normal faults. Colored numbers: 1 - red arrows: high-temperature hydrothermal convective cells. 2- blue arrows: mixing with cold seawater. Black numbers: 1high-temperature sulfide chimneys (red triangles) rooted on altered lava and stockwork mineralization (red crosshatching). 2- low-temperature Fe/Mn hydrothermal mineralization (brown patches).

Figure 20: Stage 2 - End of the collapse of the magma chamber and caldera formation. A: lava flows. B: fractured volcanic basement. M: magma chamber. Caldera faults: red line = reverse faults; dark blue lines: normal faults. Colored numbers: 1- blue arrows: Lowtemperature hydrothermal convective cells. Black numbers = hydrothermal precipitates: 1outcrop of hydrothermal alteration and stockwork mineralization (red crosshatching). 2- lowtemperature $\mathrm{Fe} / \mathrm{Mn}$ hydrothermal mineralization (brown patches). 3- low-temperature Si/Fe 
mineralization at the base of the caldera walls (orange patches. Talus and scree are not represented.

Figure 21: Stage 3: New magmatic episode and magmatic fluid venting. A: old lava flows. B: fractured volcanic basement. M: magma chamber. R: resurgent dome. C: recent lava flows and direction of flows (black arrows). Caldera faults: red dotted line = reverse faults; Dark blue lines $=$ normal faults. Colored numbers: 1 - yellow arrows: magmatic fluid. 2- red arrows: high-temperature hydrothermal convective cells and fluids generated by deep water-rock reaction. 3-blue arrows, cold seawater. Black numbers = hydrothermal precipitates: 1outcrop of hydrothermal alteration and stockwork mineralization (red crosshatching). 2- lowtemperature $\mathrm{Fe} / \mathrm{Mn}$ hydrothermal mineralization (brown patches). 3-low-temperature Si/Fe mineralization at the base of the caldera walls (orange patches). 4- native sulfur deposits generated by the discharge of magmatic fluids (yellows dots). Talus and scree are not represented.

Figure 22: Stage 4: New hydrothermal episode and high-temperature venting. A: old lava flows. B: fractured volcanic basement. $M$ : magma chamber. R: resurgent dome. C: recent lava flows. Caldera faults: red dotted line = reverse faults; dark blue lines = normal faults. Colored numbers: 1- red arrows: high-temperature hydrothermal fluid generated by deep water-rock reaction. 2- white arrows: seawater heated $\left(>250^{\circ} \mathrm{C}\right)$ at shallow levels in contact with the hot recent dyke controlled by the reverse faults (red line). This heated seawater is mixed with the hydrothermal fluid. 3- Blue arrow, cold seawater. Black numbers = hydrothermal precipitates: 1- stockwork mineralization (red crosshatching). 2- lowtemperature Fe/Mn deposits (brown patches). 3- Low-temperature Si/Fe mineralization (orange patches). 4- native sulfur deposits generated by the discharge of magmatic fluids (yellow dots). 5- recent (<1 year) black smokers sulfidic chimneys (red triangles). 6- lowtemperature silica chimney near the base of the caldera wall (yellow triangles). 7- Diffuse low-temperature venting without precipitates. Talus and scree are not represented.

\section{Table captions}

Table 1: Known deep sea calderas associated with hydrothermal sulfides deposits: 1:(Honsho et al. , 2015, lizasa et al. , 2004); 2:(Gamo et al. , 1996, Seewald et al. , 2015); 3 : (Berkenbosch et al. , 2012, Kim et al. , 2009, Lupton et al. , 2015); 4: (Falloon et al. , 1992, Lisitsyn et al. , 1992); 5: (Ligi et al. , 2014); 6: This paper; 7,8,9,10: (Lupton et al. , 2012); 11 : 
(Anderson et al. , 2015); 12: (lizasa et al. , 1999, Tanahashi et al. , 2008); 13: (lizasa et al. , 1992); 14: (Tsunogai et al. , 1994); 15: (Urabe et al. , 1987); 16: (Gamo et al. , 2004); 17: (Hein et al. , 2014); 18:(Stern et al. , 2008); 19: (Brounce et al. , 2016); 20: (Lupton et al. , 2008); 21: (Stuben et al. , 1992) 22-23: (Stoffers et al. , 2006); 24: (de Ronde et al. , 2005, de Ronde et al. , 2011); 25:(de Ronde et al. , 2001, Wright et al. , 2003); 26: (Leybourne et al. 2012b); 27: (Boschen et al. , 2013); 28: (CASM, 1985, Hannington and Scott, 1988); 29: (Haymon et al. , 2008).

Table 2: Chemical compositions of representative lava samples collected from the Kulo Lasi volcano. Old lava are in red and young lava in blue in figs 6,7 and 8.

Table 3: fluid compositions (Konn et al. , 2018). Samples TiG3 and TiD3 correspond to the chimney sample FU-PL-06-02 and samples TiG1 and TiD1 correspond to the chimney sample FU-PL-06-03. See location of samples on figure 13. End-members are calculated in this paper, considering mixing between deep hydrothermal fluid generated by water-rock reaction and shallow seawater heated by the recent dike. The temperature estimated using the Fe/Mn geothermometer (Pester et al. , 2011) is indicated. See text for details.

Table 4: Results of XRF and XRD analyses of sulfides and sulfates chimneys. See Fig. 13 for correspondence between chimneys and fluid samples. Zn-rich and Fe-rich samples are from inactive chimneys. For the location: $\mathrm{NW}=$ North West part of the caldera. $\mathrm{E}=$ Eastern part of the caldera. The lower part of the table shows the mineral proportions determined from X-ray diffraction data and calculated using the TOPAS software. Estimating the proportion of amorphous phases (opal, iron oxyhydroxydes) is not possible; values proposed are therefore semi quantitative.

Table 5: Average composition of sulfide mineralization in typical oceanic environments. Source of data: $(1)=($ Fouquet et al. , 1996); $(2,3,4,14)=$ Fouquet, unpublished data; (5 to 12) $=($ Fouquet et al. , 2010); $(13,16,17,19,20,23,24,25,26,27,28,29)=($ Hannington et al. , 2005.) and references therein; $(15)=$ (Bendel et al. , 1993); (18) = this study. $(21,22)=$ (Fouquet et al. , 1993). MORB = Mid-Ocean Ridge Basalt, E-MORB = Enriched MORB; $\mathrm{BABB}=$ back-arc basin basalt; IAB = Island-arc tholeite.

Table 6: Chemical composition of Si-Fe hydrothermal sediments 


\section{References}

Acocella, V., 2007. Understanding caldera structure and development: An overview of analogue models compared to natural calderas. Earth-Science Reviews 85, 125 160.

Acocella, V., Cifelli, F., Funiciello, R., 2000. Analogue models of collapse calderas and resurgent domes. Journal of Volcanology and Geothermal Research 104, 81-96.

Acocella, V., Cifelli, F., Funiciello, R., 2001. The control of overburden thickness on resurgent domes: insights from analogue models. Journal of Volcanology and Geothermal Research 111, 137-153.

Acocella, V., Funiciello, R., Marotta, E., Orsi, G., de Vita, S., 2004. The role of extensional structures on experimental calderas and resurgence. Journal of Volcanology and Geothermal Research 129, 199-217.

Allen, D.E., Seyfried, W.E., 2003. Compositional controls on vent fluids from ultramatichosted hydrothermal systems at mid-ocean ridges: An experimental study at $400^{\circ} \mathrm{C}$, 500 bars. Geochimica Et Cosmochimica Acta 67, 1531-1542.

Anders, E., Grevesse, N., 1989. Abundance of the elements - meteoric and solar. Geochimica Et Cosmochimica Acta 53, 197-214.

Anderson, M., Hannington, M.D., Haase, K.M., Schwarz-Schampera, U., McConackty, T., 2015. Geological control on hydrothermal venting at the Nifonea volcano, Vate Trough, Vanuatu. Mineral resources in a sustainable world. 13th Bienneal meeting SGA; 1215-1218.

Auzende, J.M., Halbach, P., Allspach, A., Becker, K., Blum, N., Bonnier, O.L., Van Gerven, M., Halbach, M., Koschinsky, A., 1995. Tectonic, magmatic and hydrothermal activity around the triple-junctions of the North Fiji Basin (16 $50^{\circ} \mathrm{S}-173^{\circ} 30^{\prime} \mathrm{E}$ and $\left.16^{\circ} 30^{\prime} S-176^{\circ} 10^{\prime} E\right)$ (SW Pacific): Hyfiflux cruise. Comptes rendus de l'Academie des Sciences 321, 239-246.

Auzende, J.M., Urabe, T., Binns, R., Charlou, L.L., Gena, K., Gamo, T., Henry, K., Matsubayashi, O., Matsumoto, T., Moss, R., Naka, J., Nagaya, Y., Okamura, K., Ruellan, E., 1996. Tectonic, magmatic and hydrothermal activity in the Manus basin (SW Pacific, Papua New Guinea): MANUSFLUX cruise, Shinkai-6500. Comptes Rendus de l'Academie des Sciences 323, 501-508.

Bach, W., Seewald, J.S., Tivey, M.A., Tivey, M.K., Yoerger, D., Craddock, P.R., Anonymous. 2007. Hydrothermal systems in the eastern Manus Basin; effects of phase separation and fluid mixing. Geochimica et Cosmochimica Acta. New York: Elsevier, A48.

Baker, E.T., Embley, R.W., Walker, S.L., Resing, J.A., Lupton, J.E., Nakamura, K.-i., de Ronde, C.E.J., Massoth, G.J., 2008. Hydrothermal activity and volcano distribution along the Mariana Arc. Journal of Geophysical Research 113, 1-15.

Baker, E.T., Fox, C.G., Cowen, J.P., 1999. In situ observations of the onset of hydrothermal discharge during the 1998 submarine eruption of Axial Volcano, Juan de Fuca Ridge. Geophysical Research Letters 26, 3445-3448.

Baker, E.T., Lupton, J.E., Resing, J.A., Baumberger, T., Lilley, M.D., Walker, S.L., Rubin, K.H., 2011. Unique event plumes from a 2008 eruption on the Northeast Lau Spreading Center. Geochemistry Geophysics Geosystems 12, 1-21.

Baker, E.T., Martinez, F., Resing, J.A., Walker, S.L., Buck, N.J., Edwards, M.H., 2010. Hydrothermal cooling along the Eastern Lau Spreading Center: No evidence for discharge beyond the neovolcanic zone. Geochemistry Geophysics Geosystems 11, $1-15$.

Baker, E.T., Massoth, G.J., Nakamura, K., Embley, R.W., de Ronde, C.E.J., Arculus, R.J., 2005. Hydrothermal activity on near-arc sections of back-arc ridges: Results from the Mariana Trough and Lau Basin. Geochemistry Geophysics Geosystems 6, 1-15. 
Baker, E.T., Resing, J.A., Walker, S.L., Martinez, F., Taylor, B., Nakamura, K., 2006. Abundant hydrothermal venting along melt-rich and melt-free ridge segments in the Lau back-arc basin. Geophysical Research Letters 33, 1-4.

Baker, E.T., Walker, S.L., Embley, R.W., de Ronde, C.E.J., 2012. High-Resolution Hydrothermal Mapping of Brothers Caldera, Kermadec Arc. Economic Geology 107, 1583-1593.

Barker, S.J., Wilson, C.J.N., Baker, J.A., Millet, M.A., Rotella, M.D., Wright, I.C., Wysoczanski, R.J., 2013. Geochemistry and Petrogenesis of Silicic Magmas in the Intra-Oceanic Kermadec Arc. Journal of Petrology 54, 351-391.

Baumberger, T., Lilley, M.D., Resing, J.A., Lupton, J.E., Baker, E.T., Butterfield, D.A., Olson, E.J., Frueh-Green, G.L., 2014. Understanding a submarine eruption through time series hydrothermal plume sampling of dissolved and particulate constituents: West Mata, 2008-2012. Geochemistry Geophysics Geosystems 15, 4631-4650.

Bendel, V., Fouquet, Y., Auzende, J.M., Lagabrielle, Y., Grimaud, D., Urabe, T., 1993. The White-Lady hydrothermal field, north Fiji back-arc basin, southwest Pacific. Economic Geology 88, 2237-2249.

Bennett, S.A., Statham, P.J., Green, D.R.H., Le Bris, N., McDermott, J.M., Prado, F., Rouxel, O.J., Von Damm, K., German, C.R., 2011. Dissolved and particulate organic carbon in hydrothermal plumes from the East Pacific Rise, $9^{\circ} 50^{\prime} N$. Deep-Sea Research Part I-Oceanographic Research Papers 58, 922-931.

Berkenbosch, H.A., de Ronde, C.E.J., Gemmell, J.B., McNeill, A.W., Goemann, K., 2012. Mineralogy and Formation of Black Smoker Chimneys from Brothers Submarine Volcano, Kermadec Arc. Economic Geology 107, 1613-1633.

Berkenbosch, H.A., de Ronde, C.E.J., Paul, B.T., Gemmell, J.B., 2015. Characteristics of Cu isotopes from chalcopyrite-rich black smoker chimneys at Brothers volcano, Kermadec arc, and Niuatahi volcano, Lau basin. Mineralium Deposita 50, 811-824.

Berndt, M.E., Allen, D.E., Seyfried, W.E., 1996. Reduction of CO2 during serpentinization of olivine at $300^{\circ} \mathrm{C}$ and 500 bar. Geology 24, 351-354.

Bertine, K.K., Keene, J.B., 1975. Submarine Barite-Opal Rocks of Hydrothermal Origin. Science 188, 150-152.

Bevis, M., Taylor, F.W., Schutz, B.E., Recy, J., Isacks, B.L., Helu, S., Singh, R., Kendrick, E., Stowell, J., Taylor, B., Calmant, S., 1995. Geodetic observations of very rapid convergence and back-arc extension at the Tonga Arc. Nature 374, 249-251.

Binns, R.A., Scott, S.D., 1993. Actively forming polymetallic sulfide deposits associated with felsic volcanic rocks in the eastern Manus back-arc basin, Papua New Guinea. Economic Geology and the Bulletin of the Society of Economic Geologists 88, 22262236.

Bischoff, J.L., Pitzer, K.S., 1989. Liquid-vapor relations for the system NaCl-H20 - summary of the P-T-X surface from $300^{\circ} \mathrm{C}$ to $500^{\circ} \mathrm{C}$. American Journal of Science 289, 217 248.

Bischoff, J.L., Rosenbauer, R.J., 1984. The critical-point and 2-phase boundary of seawater, 200-500 ${ }^{\circ}$ C. Earth and Planetary Science Letters 68, 172-180.

Bischoff, J.L., Rosenbauer, R.J., 1985. An empirical-equation of state for hydrothermal seawater $(3.2 \% \mathrm{NaCl})$. American Journal of Science 285, 725-763.

Bischoff, J.L., Rosenbauer, R.J., 1987. Phase-separation in seafloor geothermal systems an experimental-study of the effects on metal transport. American Journal of Science 287, 953-978.

Boschen, R.E., Tyler, P.A., Copley, J.T., 2013. Distribution, population structure, reproduction and diet of Ophiolimna antarctica (Lyman, 1879) from Kemp Caldera in the Southern Ocean. Deep-Sea Research Part li-Topical Studies in Oceanography 92, 27-35.

Both, R., Crook, K., Taylor, B., Brogan, S., Chappell, B., Frankel, E., Liu, L., Sinton, J., Tiffin, D., 1986. Hydrothermal chimneys and associated fauna in the Manus Back-arc basin, Papua New Guinea. EOS: American Geophysical Union Transactions 67, 489-490. 
Branney, M.J., 1995. Downsag and extension at calderas - new perspectives on collapse geometries from ice-melt, mining, and volcanic subsidence. Bulletin of Volcanology 57, 303-318.

Brounce, M., Kelley, K.A., Stern, R., Martinez, F., Cottrell, E., 2016. The Fina Nagu volcanic complex: Unusual submarine arc volcanism in the rapidly deforming southern Mariana margin. Geochemistry Geophysics Geosystems 17, 4078-4091.

Burchardt, S., Walter, T.R., 2010. Propagation, linkage, and interaction of caldera ring-faults: comparison between analogue experiments and caldera collapse at Miyakejima, Japan, in 2000. Bulletin of Volcanology 72, 297-308.

Butterfield, D.A., Nakamura, K.-i., Takano, B., Lilley, M.D., Lupton, J.E., Resing, J.A., Roe, K.K., 2011. High SO2 flux, sulfur accumulation, and gas fractionation at an erupting submarine volcano. Geology 39, 803-806.

CASM. 1985. Hydrothermal vents on an axis seamount of the Juan-de Fuca- Ridge. Nature 313, 212-214.

Chadwick, W.W., Howard, K.A., 1991. The pattern of circumferential and radial eruptive fissures on the volcanos of Fernandina and Isabela islands, Galapagos. Bulletin of Volcanology 53, 259-275.

Charlou, J.L., Donval, J.P., 1993. Hydrothermal methane venting between $12^{\circ} \mathrm{N}$ and $26^{\circ} \mathrm{N}$ along the Mid-Atlantic Ridge. Journal of Geophysical Research-Solid Earth 98, 9625-9642.

Charlou, J.L., Donval, J.P., Konn, C., Ondreas, H., Fouquet, Y., Jean Baptiste, P., Fourré, E., 2010. High production and fluxes of $\mathrm{H} 2$ and $\mathrm{CH} 4$ and evidence of abiotic hydrocarbon synthesis by serpentinization in ultramafic-hosted hydrothermal systems on the Mid- Atlantic Ridge. Diversity of Hydrothermal Systems on Slowspreading Ocean Ridges: AGU monograph 188, 265-296.

Charlou, J.L., Fouquet, Y., Donval, J.P., Auzende, J.M., JeanBaptiste, P., Stievenard, M., Michel, S., 1996. Mineral and gas chemistry of hydrothermal fluids on an ultrafast spreading ridge: East Pacific Rise, $17^{\circ}$ to $19^{\circ} \mathrm{S}$ (Naudur cruise, 1993) phase separation processes controlled by volcanic and tectonic activity. Journal of Geophysical Research-Solid Earth 101, 15899-15919.

Christie, D.M., Carmichael, I.S.E., Langmuir, C.H., 1986. Oxidation-states of midocean ridge basalt glasses. Earth and Planetary Science Letters 79, 397-411.

Clague, D.A., Moore, J.G., Reynolds, J.R., 2000. Formation of submarine flat-topped volcanic cones in Hawaii. Bulletin of Volcanology 62, 214-233.

Cole, J.W., Milner, D.M., Spinks, K.D., 2005. Calderas and caldera structures: a review. Earth-Science Reviews 69, 1-26.

Corbi, F., Rivalta, E., Pinel, V., Maccaferri, F., Acocella, V., 2016. Understanding the link between circumferential dikes and eruptive fissures around calderas based on numerical and analog models. Geophysical Research Letters 43, 6212-6219.

de Ronde, C.E.J., Baker, E.T., Massoth, G.J., Lupton, J.E., Wright, I.C., Feely, R.A., Greene, R.R., 2001. Intra-oceanic subduction-related hydrothermal venting, Kermadec volcanic arc, New Zealand. Earth and Planetary Science Letters 193, 359-369.

de Ronde, C.E.J., Chadwick, W.W., Ditchburn, R.G., Embley, R.W., Tunnicliffe, V., Baker, E.T., Walker, S.L., Ferrini, V.L., Merle, S.M., 2015. Molten sulfur lakes of intraoceanic arc volcanoes. . In: D. Rouwet BC, F. Tassi \& J. Vandelbroulemuck, editor. Volcanic Lakes Springer-Verlag Berlin Heidelberg, 261-288.

de Ronde, C.E.J., Faure, K., Bray, C.J., Chappell, D.A., Wright, I.C., 2003. Hydrothermal fluids associated with seafloor mineralization at two southern Kermadec Arc volcanoes, offshore New Zealand. Mineralium Deposita 38, 217-233.

de Ronde, C.E.J., Hannington, M.D., Stoffers, P., Wright, I.C., Ditchburn, R.G., Reyes, A.G., Baker, E.T., Massoth, G.J., Lupton, J.E., Walker, S.L., Greene, R.R., Soong, C.W.R., Ishibashi, J., Lebon, G.T., Bray, C.J., Resing, J.A., 2005. Evolution of a submarine magmatic-hydrothermal system: Brothers volcano, southern Kermadec arc, New Zealand. Economic Geology 100, 1097-1133. 
de Ronde, C.E.J., Hein, J.R., Butterfield, D.A., 2014a. Metallogenesis and Mineralization of Intraoceanic Arcs II: The Aeolian, Izu-Bonin, Mariana, and Kermadec Arcs, and the Manus Backarc Basin-Introduction. Economic Geology 109, 2073-2077.

de Ronde, C.E.J., Massoth, G.J., Butterfield, D.A., Christenson, B.W., Ishibashi, J., Ditchburn, R.G., Hannington, M.D., Brathwaite, R.L., Lupton, J.E., Kamenetsky, V.S., Graham, I.J., Zellmer, G.F., Dziak, R.P., Embley, R.W., Dekov, V.M., Munnik, F., Lahr, J., Evans, L.J., Takai, K., 2011. Submarine hydrothermal activity and goldrich mineralization at Brothers Volcano, Kermadec Arc, New Zealand. Mineralium Deposita 46, 541-584.

de Ronde, C.E.J., Stucker, V.K., 2015. Seafloor hydrothermal venting at volcanic arcs and backarcs. Encyclopaedia of Volcanoes: Academic Press., 823-849.

de Ronde, C.E.J., Walker, S.L., Ditchburn, R.G., Tontini, F.C., Hannington, M.D., Merle, S.G., Timm, C., Handler, M.R., Wysoczanski, R.J., Dekov, V.M., Kamenov, G.D., Baker, E.T., Embley, R.W., Lupton, J.E., Stoffers, P., 2014b. The Anatomy of a Buried Submarine Hydrothermal System, Clark Volcano, Kermadec Arc, New Zealand. Economic Geology 109, 2261-2292.

Dupre, S., Buffet, G., Mascle, J., Foucher, J.P., Gauger, S., Boetius, A., Marfia, C., Aster, X.A.U.V.T., Quest, R.O.V.T., Party, B.S., 2008. High-resolution mapping of large gas emitting mud volcanoes on the Egyptian continental margin (Nile Deep Sea Fan) by AUV surveys. Marine Geophysical Research 29, 275-290.

Eddy, C.A., Dilek, Y., Hurst, S., Moores, E.M., 1998. Seamount formation and associated caldera complex and hydrothermal mineralization in ancient oceanic crust, Troodos ophiolite (Cyprus). Tectonophysics 292, 189-210.

Elston, W.E., 1994. Siliceous volcanic centers as guides to mineral exploration - review and summary. Economic Geology 89, 1662-1686.

Embley, R.W., Chadwick, W.W., Baker, E.T., Butterfield, D.A., Resing, J.A., De Ronde, C.E.J., Tunnicliffe, V., Lupton, J.E., Juniper, S.K., Rubin, K.H., Stern, R.J., Lebon, G.T., Nakamura, K., Merle, S.G., Hein, J.R., Wiens, D.A., Tamura, Y., 2006. Longterm eruptive activity at a submarine arc volcano. Nature 441, 494-497.

Embley, R.W., de Ronde, C.E.J., Merle, S.G., Davy, B., Tontini, F.C., 2012. Detailed Morphology and Structure of an Active Submarine Arc Caldera: Brothers Volcano, Kermadec Arc. Economic Geology 107, 1557-1570.

Evans, G.N., Tivey, M.K., Seewald, J.S., Wheat, C.G., 2017. Influences of the Tonga Subduction Zone on seafloor massive sulfide deposits along the Eastern Lau Spreading Center and Valu Fa Ridge. Geochimica Et Cosmochimica Acta 215, 214246.

Evrard, C., Fouquet, Y., Moelo, Y., Rinnert, E., Etoubleau, J., Langlade, J.A., 2015. Tin concentration in hydrothermal sulphides related to ultramafic rocks along the MidAtlantic Ridge: a mineralogical study. European Journal of Mineralogy 27, 627-638.

Falloon, T.J., Malahoff, A., Zonenshain, L.P., Bogdanov, Y., 1992. Petrology and geochemistry of back-arc basin basalts from Lau basin spreading ridges at $15^{\circ} 18^{\circ}$ and $19^{\circ} \mathrm{S}$. Mineralogy and Petrology 47, 1-35.

Fiske, R.S., Naka, J., lizasa, K., Yuasa, M., Klaus, A., 2001. Submarine silicic caldera at the front of the Izu-Bonin Arc, Japan; voluminous seafloor eruptions of rhyolite pumice. Geological Society of America Bulletin 113, 813-824.

Fontaine, F.J., Wilcock, W.S.D., Foustoukos, D.E., Butterfield, D.A., 2009. A Si-Cl geothermobarometer for the reaction zone of high-temperature, basaltic-hosted midocean ridge hydrothermal systems. Geochemistry Geophysics Geosystems 10, 1-9.

Fouquet, Y., Alix, A.S., Birot, D., Cheron, S., Charlou, J.L., Donval, J.P., Etoubleau, J., Germain, Y., Guillou, M., Guerin, C., Guyader, V., Konn, C., Labanieh, S., Pelleter, E., Pierre, D., Dupre, S., Scalabrin, C., Cambon, M.A., Menot, L., Pradillon, F., Chazot, G., Dyment, J., Szitkar, F., Gouin, J., 2015. Discovery of Extensive Hydrothermal Fields in the Wallis and Futuna Back-Arc Environment (SW Pacific). In: Andre-Mayer AS, Cathelineau M, Muchez P, Pirard E, Sindern S, editors. Mineral Resources in a Sustainable World, Vols 1-5 1223-1226. 
Fouquet, Y., Cambon, P., Etoubleau, J., Charlou, J.L., Ondreas, H., Barriga, F.J.A.S., Cherkashov, G., Semkova, T., Poroshina, I., Bohn, M., Donval, J.P., Henry, K., Murphy, P., Rouxel, O., 2010. Geodiversity of hydrothermal processes along the Mid-Atlantic Ridge and ultramafic-hosted mineralization: A new type of oceanic $\mathrm{Cu}$ Zn-Co-Au volcanogenic massive sulfide deposit. In: P. Rona CD, J. Dyment and B. Murton, editor. Diversity of hydrothermal systems on slow spreading ocean ridges,. AGU Monograph 188, 321-368.

Fouquet, Y., Knott, R., Cambon, P., Fallick, A., Rickard, D., Desbruyeres, D., 1996. Formation of large sulfide mineral deposits along fast spreading ridges. Example from off-axial deposits at $12^{\circ} 43^{\prime} \mathrm{N}$ on the east Pacific rise. Earth and Planetary Science Letters 144, 147-162.

Fouquet, Y., von Stackelberg, U., Charlou, J.L., Donval, J.P., Erzinger, J., Foucher, J.P., Herzig, P., Muehe, R.K., Soakai, S., Wiedicke, M., Whitechurch, H., 1991. Hydrothermal activity and metallogenesis in the Lau back-arc basin. Nature 349, 778-781.

Fouquet, Y., von Stackelberg, U., Charlou, J.L., Erzinger, J., Herzig, P.M., Muehe, R., Wiedicke, M., 1993. Metallogenesis in back-arc environments; the Lau Basin example. Economic Geology 88, 2154-2181.

Foustoukos, D.I., Seyfried, W.E., 2007a. Fluid phase separation processes in submarine hydrothermal systems. In: Liebscher A, Heinrich CA, editors. Fluid-Fluid Interactions 213-239.

Foustoukos, D.I., Seyfried, W.E., 2007b. Quartz solubility in the two-phase and critical region of the $\mathrm{NaCl}-\mathrm{KCl}-\mathrm{H} 2 \mathrm{O}$ system: Implications for submarine hydrothermal vent systems at 950'N East Pacific Rise. Geochimica Et Cosmochimica Acta 71, 186-201.

Galetto, F., Acocella, V., Caricchi, L., 2017. Caldera resurgence driven by magma viscosity contrasts. Nature Communications 8:1750, 1-11.

Galland, O., 2012. Experimental modelling of ground deformation associated with shallow magma intrusions. Earth and Planetary Science Letters 317, 145-156.

Gamo, T., Ishibashi, J., Shitashima, K., 1996. Unique hydrothermal fluid from the DESMOS caldera, Manus Basin: Reply. Deep-Sea Research Part I-Oceanographic Research Papers 43, 1873-1875.

Gamo, T., Masuda, H., Yamanaka, T., Okamura, K., Ishibashi, J., Nakayama, E., Obata, H., Shitashima, K., Nishio, Y., Hasumoto, H., Watanabe, M., Mitsuzawa, K., Seama, N., Tsunogai, U., Kouzuma, F., Sano, Y., 2004. Discovery of a new hydrothermal venting site in the southernmost Mariana Arc: Al-rich hydrothermal plumes and white smoker activity associated with biogenic methane. Geochemical Journal 38, 527534.

Gamo, T., Okamura, K., Charlou, J.L., Urabe, T., Auzende, J.M., Ishibashi, J., Shitashima, K., Chiba, H., 1997. Acidic and sulfate-rich hydrothermal fluids from the Manus back-arc basin, Papua New Guinea. Geology 25, 139-142.

Gemmell, J.B., Binns, R.A., Parr, J.M., 1999. Submarine, high sulfidation alteration within DESMOS caldera, Manus Basin, PNG. In: Stanley CJ, Rankin AH, Bodnar RJ, Naden J, Yardley BWD, Criddle AJ, et al., editors. Proceedings of the Biennial SGA Meeting, vol5 503-506.

Gena, K., Mizuta, T., Ishiyama, D., Urabe, T., 2001. Acid-sulphate type alteration and mineralization in the Desmos caldera, Manus back-arc basin, Papua New Guinea. Resource Geology 51, 31-44.

Gena, K.R., Chiba, H., Mizuta, T., Matsubaya, O., 2006. Hydrogen, oxygen and sulfur isotope studies of seafloor hydrothermal system at the Desmos caldera, Manus back-arc basin, Papua New Guinea: An analogue of terrestrial acid hot crater-lake. Resource Geology 56, 183-190.

Geshi, N., Acocella, V., Ruch, J., 2012. From structure- to erosion-controlled subsiding calderas: evidence thresholds and mechanics. Bulletin of Volcanology 74, 15531567. 
Geshi, N., Shimano, T., Chiba, T., Nakada, S., 2002. Caldera collapse during the 2000 eruption of Miyakejima Volcano, Japan. Bulletin of Volcanology 64, 55-68.

Geyer, A., Folch, A., Marti, J., 2006. Relationship between caldera collapse and magma chamber withdrawal: An experimental approach. Journal of Volcanology and Geothermal Research 157, 375-386.

Glasby, G.P., 2008. Comparison of Modern Zn-Ba-Pb Ore Deposits at Convergent Plate Margins and Fe-Cu-Zn Deposits at Divergent Plate Margins. Marine Georesources \& Geotechnology 26, 290-307.

Glasby, G.P., lizasa, K., Hannington, M., Kubota, H., Notsu, K., 2008. Mineralogy and composition of Kuroko deposits from northeastern Honshu and their possible modern analogues from the Izu-Ogasawara (Bonin) Arc south of Japan: Implications for mode of formation. Ore Geology Reviews 34, 547-560.

Graham, I.J., Reyes, A.G., Wright, I.C., Peckett, K.M., Smith, I.E.M., Arculus, R.J., 2008. Structure and petrology of newly discovered volcanic centers in the northern Kermadec-southern Tofua arc, South Pacific Ocean. Journal of Geophysical Research-Solid Earth 113, 1-24.

Gruen, G., Weis, P., Driesner, T., Heinrich, C.A., de Ronde, C.E.J., 2014. Hydrodynamic modeling of magmatic-hydrothermal activity at submarine arc volcanoes, with implications for ore formation. Earth and Planetary Science Letters 404, 307-318.

Gudmundsson, A., 1998. Formation and development of normal-fault calderas and the initiation of large explosive eruptions. Bulletin of Volcanology 60, 160-170.

Gudmundsson, A., 2016. The mechanics of large volcanic eruptions. Earth-Science Reviews 163, 72-93.

Halbach, P., Holzbecher, E., Koschinsky, A., Michaelis, W., Seifert, R., 2001. Deep-sea hydrothermal microplume generation - a case study from the North Fiji Basin. Geo Marine Letters 21, 94-102.

Halbach, P., Nakamura, K., Wahsner, M., Lange, J., Sakai, H., Kaselitz, L., Hansen, R.D., Yamano, M., Post, J., Prause, B., Seifert, R., Michaelis, W., Teichmann, F., Kinoshita, M., Marten, A., Ishibashi, J., Czerwinski, S., Blum, N., 1989. Probable modern analog of kuroko-type massive sulfide deposits in the Okinawa trough backarc basin. Nature 338, 496-499.

Halbach, P., Pracejus, B., 1993. Geology and mineralogy of massive sulfide ores from the central Okinawa trough, Japan. Economic Geology 88, 2210-2225.

Hannington, M., De Ronde, C., Petersen, S., 2005. Sea-Floor Tectonics and Submarine Hydrothermal Systems. Economic Geology, 100th Anniversary Volume, 111-141.

Hannington, M.D., Scott, S.D., 1988. Mineralogy and geochemistry of a hydrothermal silica sulfide sulfate spire in the caldera of Axial Seamount, Juan-de-Fuca Ridge. Canadian Mineralogist 26, 603-625.

Hannington, M.D., Scott, S.D., 1989. Sulfidation equilibria as guides to gold mineralization in volcanogenic massive sulfides - evidence from sulfide mineralogy and the composition of sphalerite. Economic Geology 84, 1978-1995.

Hawkesworth, C.J., Gallagher, K., Hergt, J.M., McDermott, F., 1993. Mantle and slab contributions in arc magmas. Annual Review of Earth and Planetary Sciences 21, 175-204.

Hawkins, J.W., Helu, S., . 1986. Polymetallic sulfide deposit from "black-smoker" chimney; Lau Basin. AGU 67, 378.

Haymon, R.M., White, S.M., Baker, E.T., Anderson, P.G., Macdonald, K.C., Resing, J.A., 2008. High-resolution surveys along the hot spot-affected Galapagos Spreading Center: 3. Black smoker discoveries and the implications for geological controls on hydrothermal activity. Geochemistry Geophysics Geosystems 9, 1-30.

Hedenquist, J.W., Lowenstern, J.B., 1994. The role of magmas in the formation of hydrothermal ore-deposits. Nature 370, 519-527.

Hein, J.R., de Ronde, C.E.J., Koski, R.A., Ditchburn, R.G., Mizell, K., Tamura, Y., Stern, R.J., Conrad, T.A., Ishizuka, O., Leybourne, M.I., 2014. Layered Hydrothermal Barite- 
Sulfide Mound Field, East Diamante Caldera, Mariana Volcanic Arc. Economic Geology 109, 2179-2206.

Herzig, P.M., Hannington, M.D., Arribas, A., 1998. Sulfur isotopic composition of hydrothermal precipitates from the Lau back-arc: implications for magmatic contributions to seafloor hydrothermal systems. Mineralium Deposita 33, 226-237.

Holloway, J.R., 2004. Redox reactions in seafloor basalts: possible insights into silicic hydrothermal systems. Chemical Geology 210, 225-230.

Holloway, J.R., Blank, J.G., 1994. Application of experimental results to C-O-H species in natural melts. Volatiles in Magmas 30, 187-230.

Honsho, C., Ura, T., Asada, A., Kim, K., Nagahashi, K., 2015. High-resolution acoustic mapping to understand the ore deposit in the Bayonnaise knoll caldera, IzuOgasawara arc. Journal of Geophysical Research-Solid Earth 120, 2070-2092.

Honsho, C., Ura, T., Kim, K., Asada, A., 2016. Postcaldera volcanism and hydrothermal activity revealed by autonomous underwater vehicle surveys in Myojin Knoll caldera, Izu-Ogasawara arc. Journal of Geophysical Research-Solid Earth 121, 4085-4102.

Hou, Z.Q., Zaw, K., Li, Y.H., Zhang, Q.L., Zeng, Z.G., Urabe, T., 2005. Contribution of magmatic fluid to the active hydrothermal system in the JADE field, Okinawa trough: Evidence from fluid inclusions, oxygen and helium isotopes. International Geology Review 47, 420-437.

lizasa, K., Fiske, R.S., Ishizuka, O., Yuasa, M., Hashimoto, J., Ishibashi, J., Naka, J., Horii, Y., Fujiwara, Y., Imai, A., Koyama, S., 1999. A Kuroko-type polymetallic sulfide deposit in a submarine silicic caldera. Science 283, 975-977.

lizasa, K., Sasaki, M., Matsumoto, K., Shiokawa, S., Tanahashi, M., leee. 2004. A first extensive hydrothermal field associated with Kuroko-type deposit in a silicic submarine caldera in a nascent rift zone, Izu-Ogasawara (Bonin) arc, Japan. Oceans '04 Mts/leee Techno-Ocean '04, Vols 1- 2, Conference Proceedings, Vols 14 991-996.

lizasa, K., Yuasa, M., Yokota, S., 1992. Mineralogy and geochemistry of volcanogenic sulfides from the myojinsho submarine caldera, the shichito-iwojima ridge, izuogasawara arc, northwestern pacific. Marine Geology 108, 39-58.

Ishibashi, J., Suzuki, R., Yamanaka, T., Toki, T., Kimura, H., Noguchi, T., Urabe, T., 2006. Seafloor hydrothermal activity at off-axial seamounts of backarc spreading in southern Mariana Trough. Goldschmidt Conference Abstracts A279-A279.

Ishibashi, J.i., Grimaud, D., Nojiri, Y., Auzende, J.M., Urabe, T., 1994. Fluctuation of chemical compositions of the phase-separated hydrothermal fluid from the North Fiji Basin ridge Marine-Geology 116, 215-226.

Kawasumi, S., Chiba, H., 2017. Redox state of seafloor hydrothermal fluids and its effect on sulfide mineralization. Chemical Geology 451, 25-37.

Kelley, D.S., Lilley, M.D., Lupton, J.E., Olson, E.J., 1998. Enriched H2, CH4, and $\mathrm{He} 3$ concentrations in hydrothermal plumes associated with the 1996 Gorda Ridge eruptive event. Deep-Sea Research Part Ii-Topical Studies in Oceanography 45, 2665-2682.

Kennedy, B., Stix, J., 2003. Igneous Rock Associations - 1. Styles and mechanisms of caldera collapse. Geoscience Canada 30, 59-72.

Kennedy, B., Stix, J., Vallance, J.W., Lavallee, Y., Longpre, M.A., 2004. Controls on caldera structure: Results from analogue sandbox modeling. Geological Society of America Bulletin 116, 515-524.

Kennedy, B.M., Jellinek, A.M., Stix, J., 2008. Coupled caldera subsidence and stirring inferred from analogue models. Nature Geoscience 1, 385-389.

Kim, J., Lee, I., Lee, K.Y., 2004. S, Sr, and Pb isotopic systematics of hydrothermal chimney precipitates from the Eastern Manus Basin, western Pacific: Evaluation of magmatic contribution to hydrothermal system. Journal of Geophysical Research-Solid Earth 109, 1-13.

Kim, J., Son, S.-K., Son, J.-W., Kim, K.-H., Shim, W.J., Kim, C.H., Lee, K.-Y., 2009. Venting sites along the Fonualei and Northeast Lau Spreading Centers and evidence of 
hydrothermal activity at an off-axis caldera in the northeastern Lau Basin. Geochemical Journal 43, 1-13.

Kimura, M., Uyeda, S., Kato, Y., Tanaka, T., Yamano, M., Gamo, T., Sakai, H., Kato, S., Izawa, E., Oomori, T., 1988. Active hydrothermal mounds in the Okinawa Trough backarc basin, Japan. Tectonophysics 145, 319-324.

Konn, C., Charlou, J.L., Donval, J.P., Holm, N.G., Dehairs, F., Bouillon, S., 2009. Hydrocarbons and oxidized organic compounds in hydrothermal fluids from Rainbow and Lost City ultramafic-hosted vents. Chemical Geology 258, 299-314.

Konn, C., Donval, J.P., Guyader, V., Roussel, E., Fourré, E., Jean-Baptiste, P., Pelleter, E., Charlou, J.L., Fouquet, Y., 2018. Organic, gas and element geochemistry of hydrothermal fluids of the newly discovered extensive hydrothermal area in the Wallis and Futuna region (SW Pacific). Geofluids 2018, 1-25.

Konn, C., Fourré, E., Jean-Baptiste, P., Donval, J.P., Guyader, V., Birot, D., Alix, A.S., Gaillot, A., Perez, F., Dapoigny, A., Pelleter, E., Resing, J.A., Charlou, J.L., Fouquet, Y., parties, a.s., 2016. Extensive hydrothermal activity revealed by multi-tracer survey in the Wallis and Futuna region (SWPacific). Deep-Sea Research I 116, 127-144.

Kusumoto, S., Takemura, K., 2005. Caldera geometry determined by the depth of the magma chamber. Earth Planets and Space 57, E17-E20.

Lackschewitz, K.S., Devey, C.W., Stoffers, P., Botz, R., Eisenhauer, A., Kummetz, M., Schmidt, M., Singer, A., 2004. Mineralogical, geochemical and isotopic characteristics of hydrothermal alteration processes in the active, submarine, felsichosted PACMANUS field, Manus Basin, Papua New Guinea. Geochimica Et Cosmochimica Acta 68, 4405-4427.

Lagabrielle, Y., Cormier, M.H., 1999. Formation of large summit troughs along the East Pacific Rise as collapse calderas: An evolutionary model. Journal of Geophysical Research-Solid Earth 104, 12971-12988.

Lagabrielle, Y., Garel, E., Dauteuil, O., Cormier, M.H., 2001. Extensional faulting and caldera collapse in the axial region of fast spreading ridges: Analog modeling. Journal of Geophysical Research-Solid Earth 106, 2005-2015.

Lang, S.Q., Butterfield, D.A., Lilley, M.D., Johnson, H.P., Hedges, J.I., 2006. Dissolved organic carbon in ridge-axis and ridge-flank hydrothermal systems. Geochimica Et Cosmochimica Acta 70, 3830-3842.

Lavallee, Y., Stix, J., Kennedy, B., Richer, M., Longpre, M.A., 2004. Caldera subsidence in areas of variable topographic relief: results from analogue modeling. Journal of Volcanology and Geothermal Research 129, 219-236.

Le Bas, M.J., Le Maitre, R., Streckeisen, A., Zanettin, B., 1986. A chemical classification of volcanic rocks based on the total alkali-silica diagram. Journal of Petrology $27,745-$ 750.

Leybourne, M.I., de Ronde, C.E.J., Wysoczanski, R.J., Walker, S.L., Timm, C., Gibson, H.L., Layton-Matthews, D., Baker, E.T., Clark, M.R., Tontini, F.C., Faure, K., Lupton, J.E., Fornari, D.J., Soule, S.A., Massoth, G.J., 2012a. Geology, Hydrothermal Activity, and Sea-Floor Massive Sulfide Mineralization at the Rumble II West Mafic Caldera. Economic Geology 107, 1649-1668.

Leybourne, M.I., Schwarz-Schampera, U., de Ronde, C.E.J., Baker, E.T., Faure, K., Walker, S.L., Butterfield, D.A., Resing, J.A., Lupton, J.E., Hannington, M.D., Gibson, H.L., Massoth, G.J., Embley, R.W., Chadwick, W.W., Clark, M.R., Timm, C., Graham, I.J., Wright, I.C., 2012b. Submarine Magmatic-Hydrothermal Systems at the Monowai Volcanic Center, Kermadec Arc. Economic Geology 107, 1669-1694.

Ligi, M., Cocchi, L., Bortoluzzi, G., D'Oriano, F., Muccini, F., Tontini, F.C., de Ronde, C.E.J., Carmisciano, C., 2014. Mapping of Seafloor Hydrothermally Altered Rocks Using Geophysical Methods: Marsili and Palinuro Seamounts, Southern Tyrrhenian Sea. Economic Geology 109, 2103-2117.

Lilley, M.D., Butterfield, D.A., Lupton, J.E., Olson, E.J., 2003. Magmatic events can produce rapid changes in hydrothermal vent chemistry. Nature 422, 878-881. 
Lipman, P.W., 1997. Subsidence of ash-flow calderas: relation to caldera size and magmachamber geometry. Bulletin of Volcanology 59, 198-218.

Lipman, P.W., 2000. Calderas. Academic Press, New York

Lisitsyn, A.P., Crook, K.A.W., Bogdanov, Y.A., Zonenshayn, L.P., Murav'yev, K.G., Tufar, W., Gurvich, Y.G., Gordeyev, V.V., Ivanov, G.V., 1993. A hydrothermal field in the rift zone of the Manus Basin, Bismarck Sea. International Geology Review 35, 105-126.

Lisitsyn, A.P., Malahoff, A.R., Bogdanov, Y.A., Soakai, S., Zonenshayn, L.P., Gurvich, Y.G., Murav'yev, K.G., Ivanov, G.V., 1992. Hydrothermal formations in the northern part of the Lau Basin, Pacific Ocean. International Geology Review 34, 828-847.

Lupton, J., Butterfield, D., Lilley, M., Evans, L., Nakamura, K.-i., Chadwick, W., Jr., Resing, J., Embley, R., Olson, E., Proskurowski, G., Baker, E., de Ronde, C., Roe, K., Greene, R., Lebon, G., Young, C., 2006. Submarine venting of liquid carbon dioxide on a Mariana Arc volcano. Geochemistry Geophysics Geosystems 7.

Lupton, J., Lilley, M., Butterfield, D., Evans, L., Embley, R., Massoth, G., Christenson, B., Nakamura, K.-i., Schmidt, M., 2008. Venting of a separate CO2-rich gas phase from submarine arc volcanoes: Examples from the Mariana and Tonga-Kermadec arcs. Journal of Geophysical Research B Solid Earth 113, 1-21.

Lupton, J., Resing, J., Arculus, R., Lilley, M., Embley, R., Baker, E., Butterfield, D., Nakamura, K., Crowhurst, P., Greene, R., 2009. Hydrothermal systems and recent eruptive activity in the northern Lau Basin, South Pacific Ocean. 19th Annual Goldschmidt Conference: Geochimica et Cosmochimica Acta; A804-A804.

Lupton, J., Rubin, K.H., Arculus, R., Lilley, M., Butterfield, D., Resing, J., Baker, E., Embley, R., 2015. Helium isotope, C/He-3, and Ba-Nb-Ti signatures in the northern Lau Basin: Distinguishing arc, back-arc, and hotspot affinities. Geochemistry Geophysics Geosystems 16, 1133-1155.

Lupton, J.E., Arculus, R.J., Resing, J., Massoth, G.J., Greene, R.R., Evans, L.J., Buck, N., 2012. Hydrothermal activity in the Northwest Lau Backarc Basin: Evidence from water column measurements. Geochemistry Geophysics Geosystems 13, 1-19.

Marti, J., Geyer, A., Folch, A., Gottsmann, J., 2008. A review on collapse caldera modelling. Gottsmann, J, Marti, J (Eds), Caldera Volcanism: Analysis, Modelling and Response Elsevier, Amsterdam, 233-283.

Marumo, K., Urabe, T., Goto, A., Takano, Y., Nakaseama, M., 2008. Mineralogy and isotope geochemistry of active submarine hydrothermal field at Suiyo Seamount, Izu-Bonin Arc, west Pacific Ocean. Resource Geology 58, 220-248.

Massoth, G., Baker, E., Worthington, T., Lupton, J., de Ronde, C., Arculus, R., Walker, S., Nakamura, K., Ishibashi, J., Stoffers, P., Resing, J., Greene, R., Lebon, G., 2007. Multiple hydrothermal sources along the south Tonga arc and Valu Fa Ridge. Geochemistry Geophysics Geosystems 8, 1-26.

McCollom, T.M., Seewald, J.S., 2007. Abiotic synthesis of organic compounds in deep-sea hydrothermal environments. Chemical Reviews 107, 382-401.

McLaughlin-West, E.A., Olson, E.J., Lilley, M.D., Resing, J.A., Lupton, J.E., Baker, E.T., Cowen, J.P., 1999. Variations in hydrothermal methane and hydrogen concentrations following the 1998 eruption at Axial Volcano. Geophysical Research Letters 26, 3453-3456.

McMurtry, G.M., Sedwick, P.N., Fryer, P., Vonderhaar, D.L., Yeh, H.W., 1993. Unusual geochemistry of hydrothermal vents on submarine arc volcanos - Kasuga seamounts, northern Mariana arc. Earth and Planetary Science Letters 114, 517528.

Monecke, T., Petersen, S., Hannington, M.D., 2014. Constraints on Water Depth of Massive Sulfide Formation: Evidence from Modern Seafloor Hydrothermal Systems in ArcRelated Settings. Economic Geology 109, 2079-2101.

Moss, R., Scott, S.D., 2001. Geochemistry and mineralogy of gold-rich hydrothermal precipitates from the eastern Manus Basin, Papua New Guinea. Canadian Mineralogist 39, 957-978. 
Mottl, M.J., 1983. Metabasalts, axial hot springs, and the structure of hydrothermal systems at mid-ocean ridges. Geological Society of America Bulletin 94, 161-180.

Mueller, W.U., Stix, J., Corcoran, P.L., Daigneault, R., 2009. Subaqueous calderas in the Archean Abitibi greenstone belt: An overview and new ideas. Ore Geology Reviews 35, 4-46.

Noguchi, T., Oomori, T., Tanahara, A., Taira, N., Takada, J., Taira, H., 2007. Chemical composition of hydrothermal ores from Mid-Okinawa Trough and Suiyo Seamount determined by neutron activation analysis. Geochemical Journal 41, 141-148.

Ohmoto, H., 1978. Submarine calderas - key to formation of massive sulfide deposits. Economic Geology 73, 312-313.

Ohmoto, H., 1996. Formation of volcanogenic massive sulfide deposits: The Kuroko perspective. Ore Geology Reviews 10, 135-177.

Ohmoto, H., Tanimura, S., Date, J., Takahashi, T., 1983. Geological setting of the Kuroko deposits, Japan. Economic Geology Monograph, 5, 9-54.

Paulick, H., Bach, W., 2006. Phyllosilicate alteration mineral assemblages in the active subsea-floor Pacmanus hydrothermal system, Papua New Guinea, ODP Leg 193. Economic Geology 101, 633-650.

Pelletier, B., Auzende, J.M., 1996 Geometry and structure of the Vitiaz trench lineament (SW Pacific). Marine Geophys Res, 18, 305-335.

Pelletier, B., Calmant, S., Pillet, R., 1998. Current tectonics of the Tonga-New Hebrides region. Earth and Planetary Science Letters 164, 263-276.

Pelletier, B., Lagabrielle, Y., Benoit, M., Cabioch, G., Calmant, S., Garel, E., Guivel, C., 2001. Newly identified segments of the Pacific-Australia plate boundary along the North Fiji transform zone. Earth and Planetary Science Letters 193, 347-358.

Pester, N.J., Reeves, E.P., Rough, M.E., Ding, K., Seewald, J.S., Seyfried, W.E., Jr., 2012. Subseafloor phase equilibria in high-temperature hydrothermal fluids of the Lucky Strike Seamount (Mid-Atlantic Ridge, 371'N). Geochimica Et Cosmochimica Acta 90, 303-322.

Pester, N.J., Rough, M., Ding, K., Seyfried, W.E., 2011. A new Fe/Mn geothermometer for hydrothermal systems: Implications for high-salinity fluids at $13^{\circ} \mathrm{N}$ on the East Pacific Rise. Geochimica Et Cosmochimica Acta 75, 7881-7892.

Petersen, S., Herzig, P.M., Kuhn, T., Franz, L., Hannington, M.D., Monecke, T., Gemmell, J.B., 2005. Shallow drilling of seafloor hydrothermal systems using the BGS rockdrill; conical seamount (New Ireland Fore-Arc) and PACMANUS (eastern Manus Basin), Papua New Guinea. Marine Georesources \& Geotechnology 23, 175-193.

Petersen, S., Monecke, T., Westhues, A., Hannington, M.D., Gemmell, J.B., Sharpe, R., Peters, M., Strauss, H., Lackschewitz, K., Augustin, N., Gibson, H., Kleeberg, R., 2014. Drilling Shallow-Water Massive Sulfides at the Palinuro Volcanic Complex, Aeolian Island Arc, Italy. Economic Geology 109, 2129-2157.

Resing, J.A., Lebon, G., Baker, E.T., Lupton, J.E., Embley, R.W., Massoth, G.J., Chadwick, W.W., Jr., de Ronde, C.E.J., 2007. Venting of acid-sulfate fluids in a high-sulfidation setting at NW Rota-1 submarine volcano on the Mariana Arc. Economic Geology 102, 1047-1061.

Resing, J.A., Rubin, K.H., Embley, R.W., Lupton, J.E., Baker, E.T., Dziak, R.P., Baumberger, T., Lilley, M.D., Huber, J.A., Shank, T.M., Butterfield, D.A., Clague, D.A., Keller, N.S., Merle, S.G., Buck, N.J., Michael, P.J., Soule, A., Caress, D.W., Walker, S.L., Davis, R., Cowen, J.P., Reysenbach, A.-L., Thomas, H., 2011. Active submarine eruption of boninite in the northeastern Lau Basin. Nature Geoscience 4, 799-806.

Resing, J.A., Sansone, F.J., 1999. The chemistry of lava-seawater interactions: The generation of acidity. Geochimica Et Cosmochimica Acta 63, 2183-2198.

Resing, J.A., Sansone, F.J., 2002. The chemistry of lava-seawater interactions II: The elemental signature. Geochimica Et Cosmochimica Acta 66, 1925-1941.

Roche, O., de Vries, B.V., Druitt, T.H., 2001. Sub-surface structures and collapse mechanisms of summit pit craters. Journal of Volcanology and Geothermal Research 105, 1-18. 
Roche, O., Druitt, T.H., 2001. Onset of caldera collapse during ignimbrite eruptions. Earth and Planetary Science Letters 191, 191-202.

Roche, O., Druitt, T.H., Merle, O., 2000. Experimental study of caldera formation. Journal of Geophysical Research-Solid Earth 105, 395-416.

Rytuba, J.J., 1994. Evolution of volcanic and tectonic features in caldera settings and their importance in the localization of ore-deposits. Economic Geology and the Bulletin of the Society of Economic Geologists 89, 1687-1696.

Sansone, F.J., Resing, J.A., 1995. Hydrography and geochemistry of sea-surface hydrothermal plumes resulting from hawaiian coastal volcanism. Journal of Geophysical Research-Oceans 100, 13555-13569.

Sansone, F.J., Resing, J.A., Tribble, G.W., Sedwick, P.N., Kelly, K.M., Hon, K., 1991. Lavaseawater interactions at shallow-water submarine lava flows. Geophysical Research Letters 18, 1731-1734.

Sansone, F.J., Wen, X., Holmes, M.E., Resing, J.A., Rust, T.M., A., M.E., 1996. Dissolved gases in Loihi hydrothermal plumes following the 1996 seismic event. In: Trans E, editor. AGU, Fall Meet F398.

Scaillet, B., Pichavant, M., 2003. Experimental constraints on volatile abundances in arc magmas and their implications for degassing processes. In: Oppenheimer C, Pyle DM, Barclay J, editors. Volcanic Degassing, 23-52.

Scandone, R., Acocella, V., 2007. Control of the aspect ratio of the chamber roof on caldera formation during silicic eruptions. Geophysical Research Letters 34, 1-4.

Scott, S.D., 1997. Submarine Hydrothermal Systems and Deposits. In: Barnes HL, editor. Geochemistry of hydrothermal ore deposits: Wiley and Sons, Inc, 797-876.

Seewald, J.S., Reeves, E.P., Bach, W., Saccocia, P.J., Craddock, P.R., Shanks, W.C., III, Sylva, S.P., Pichler, T., Rosner, M., Walsh, E., 2015. Submarine venting of magmatic volatiles in the Eastern Manus Basin, Papua New Guinea. Geochimica Et Cosmochimica Acta 163, 178-199.

Seewald, J.S., Seyfried, W.E., 1990. The effect of temperature on metal mobility in subseafloor hydrothermal systems - constraints from basalt alteration experiments. Earth and Planetary Science Letters 101, 388-403.

Seyfried, W.E., 1987. Experimental and theoretical constraints on hydrothermal alteration processes at mid-ocean ridges. Annual Review of Earth and Planetary Sciences 15, 317-335.

Sharp, J.H., Carlson, C.A., Peltzer, E.T., Castle-Ward, D.M., Savidge, K.B., Rinker, K.R., 2002. Final dissolved organic carbon broad community intercalibration and preliminary use of DOC reference materials. Marine Chemistry 77, 239-253.

Stern, R.J., Tamura, Y., Embley, R.W., Ishizuka, O., Merle, S.G., Basu, N.K., Kawabata, H., Bloomer, S.H., 2008. Evolution of West Rota volcano, an extinct submarine volcano in the southern Mariana Arc: Evidence from sea floor morphology, remotely operated vehicle observations and Ar40-Ar39 geochronological studies. Island Arc 17, 70-89.

Stix, J., Kennedy, B., Hannington, M., Gibson, H., Fiske, R., Mueller, W., Franklin, J., 2003. Caldera-forming processes and the origin of submarine volcanogenic massive sulfide deposits. Geology 31, 375-378.

Stoffers, P., Worthington, T.J., Schwarz-Schampera, U., Hannington, M.D., Massoth, G.J., Hekinian, R., Schmidt, M., Lundsten, L.J., Evans, L.J., Vaiomo'unga, R., Kerby, T., 2006. Submarine volcanoes and high-temperature hydrothermal venting on the Tonga arc, southwest Pacific. Geology 34, 453-456.

Stuben, D., Bloomer, S.H., Taibi, N.E., Neumann, T., Bendel, V., Puschel, U., Barone, A., Lange, A., Wu, S.Y., Li, C.H., Zhang, D.Y., 1992. 1st results of study of sulfur-rich hydrothermal activity from an island-arc environment - Esmeralda Bank in the Mariana Arc. Marine Geology 103, 521-528.

Stucker, V.K., Walker, S.L., de Ronde, C.E.J., Tontini, F.C., Tsuchida, S., 2017. Hydrothermal Venting at Hinepuia Submarine Volcano, Kermadec Arc: 
Understanding Magmatic-Hydrothermal Fluid Chemistry. Geochemistry Geophysics Geosystems 18, 3646-3661.

Tanahashi, M., Fujioka, K., Machida, S., 2008. Myojin Rift, Izu-Bonin arc as the modern analog of Hokuroku Basin, northeast Japan: Geotectonic significance of the new hydrothermal deposit in the Back-Arc Rift. Resource Geology 58, 301-312.

Tatsumi, Y., Eggins, S., 1995. Subduction zone magmatism Blackwell Science, Boston;

Taylor, B., Crook, K., Sinton, J., 1986. Fast spreading and sulfide deposition in Manus backarc basin. Aapg Bulletin-American Association of Petroleum Geologists 70, 936-937.

Tivey, M.K., Becker, E., Beinart, R., Fisher, C.R., Girguis, P.R., Langmuir, C.H., Michael, P.J., Reysenbach, A.L., 2012. Links from Mantle to Microbe at the Lau Integrated Study Site insights from a back-arc spreading center. Oceanography 25, 62-77.

Tontini, F.C., Davy, B., de Ronde, C.E.J., Embley, R.W., Leybourne, M., Tivey, M.A., 2012. Crustal Magnetization of Brothers Volcano, New Zealand, Measured by Autonomous Underwater Vehicles: Geophysical Expression of a Submarine Hydrothermal System. Economic Geology 107, 1571-1581.

Tsunogai, U., Ishibashi, J., Wakita, H., Gamo, T., Watanabe, K., Kajimura, T., Kanayama, S., Sakai, H., 1994. Peculiar features of Suiyo seamount hydrothermal fluids, Izu-bonin arc - differences from subaerial volcanism. Earth and Planetary Science Letters 126, 289-301.

Urabe, T., Yuasa, M., Nakao, S., 1987. Hydrothermal sulfides from a submarine caldera in the Shichito-Iwojima ridge, northwestern pacific. Marine Geology 74, 295-299.

Von Damm, K.L., 1995. Controls on the chemistry and temporal variability of seafloor hydrothermal fluids. In: Humphris SE, Zierenberg RA, Mullineaux LS, Thomson RE, editors. Seafloor Hydrothermal Systems: Physical, Chemical, Biological, and Geological Interactions: AGU monograph 91, 222-247.

Von Damm, K.L., 2000. Chemistry of hydrothermal vent fluids from $9^{\circ}-10^{\circ} \mathrm{N}$, East Pacific Rise: "Time zero," the immediate posteruptive period. Journal of Geophysical Research-Solid Earth 105, 11203-11222.

Von Damm, K.L., Edmond, J.M., Grant, B., Measures, C.I., 1985. Chemistry of submarine hydrothermal solutions at $21^{\circ} \mathrm{N}$, East Pacific Rise. Geochimica Et Cosmochimica Acta 49, 2197-2220.

Von Stackelberg, U., 1988. Active hydrothermalism in the Lau Back-Arc Basin (SW Pacific) : first results from the SONNE 48 Cruise. Marine Mining, 431-442.

Wright, I.C., Gamble, J.A., 1999. Southern Kermadec submarine caldera arc volcanoes (SW Pacific): caldera formation by effusive and pyroclastic eruption. Marine Geology 161, 207-227.

Wright, I.C., Gamble, J.A., Shane, P.A.R., 2003. Submarine silicic volcanism of the Healy caldera, southern Kermadec arc (SW Pacific): I - volcanology and eruption mechanisms. Bulletin of Volcanology 65, 15-29.

Wright, I.C., Worthington, T.J., Gamble, J.A., 2006. New multibeam mapping and geochemistry of the $30^{\circ}-35^{\circ} \mathrm{S}$ sector, and overview, of southern Kermadec arc volcanism. Journal of Volcanology and Geothermal Research 149, 263-296.

Yang, K., Scott, S.D., 1996. Possible contribution of a metal-rich magmatic fluid to a sea-floor hydrothermal system. Nature 383, 420-423.

Yang, K., Scott, S.D., 2002. Magmatic degassing of volatiles and ore metals into a hydrothermal system on the modern sea floor of the eastern Manus back-arc basin, western Pacific. Economic Geology 97, 1079-1100. 
Fouquet et al. ORGEO-2017-381

Figures 


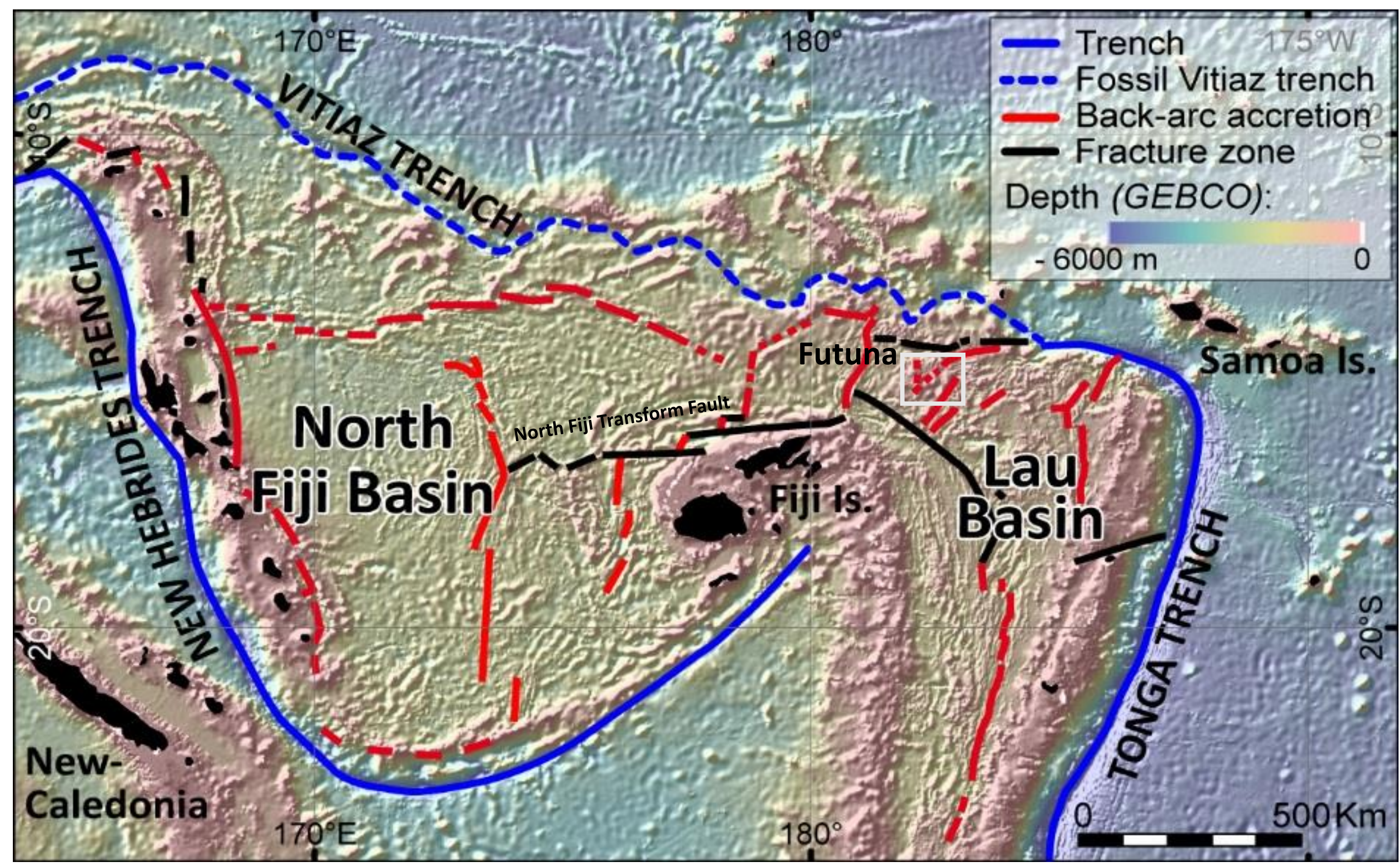

Figure 1 - in colors

Fouquet et al.

ORGEO-2017-381 


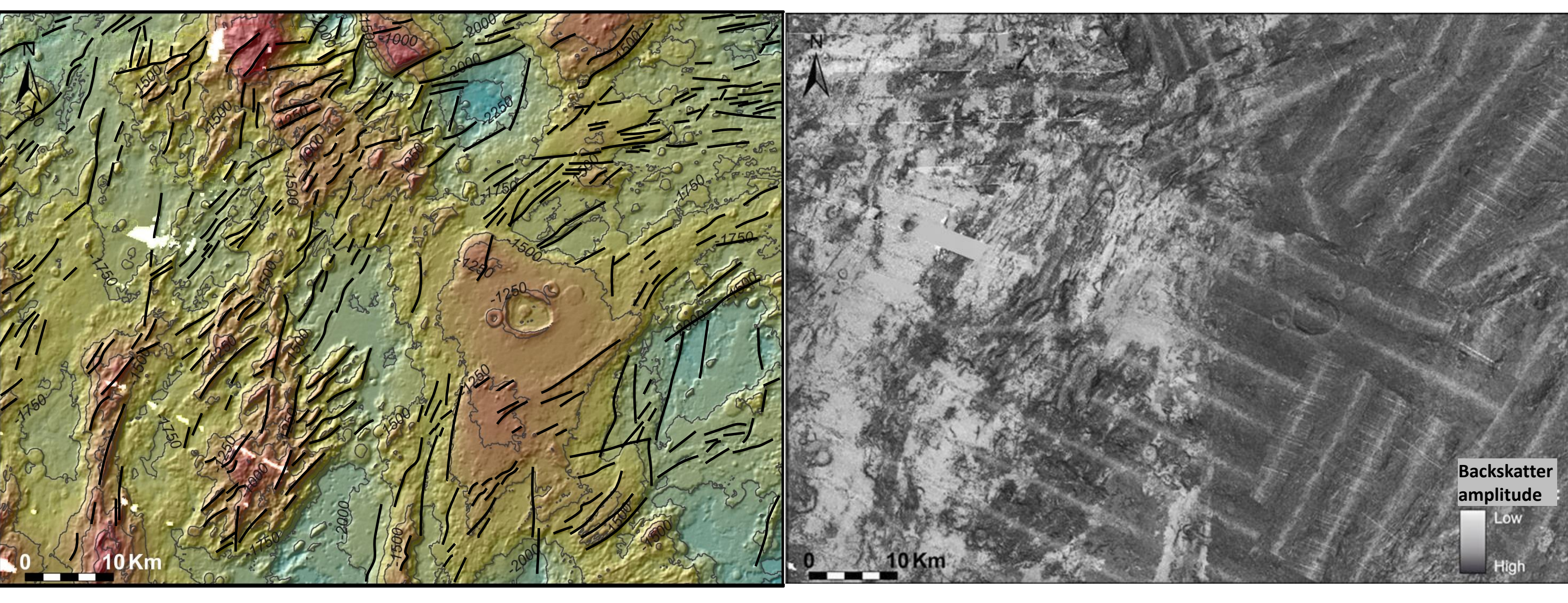

Figure 2 - in colors

Fouquet et al. ORGEO-2017-381 


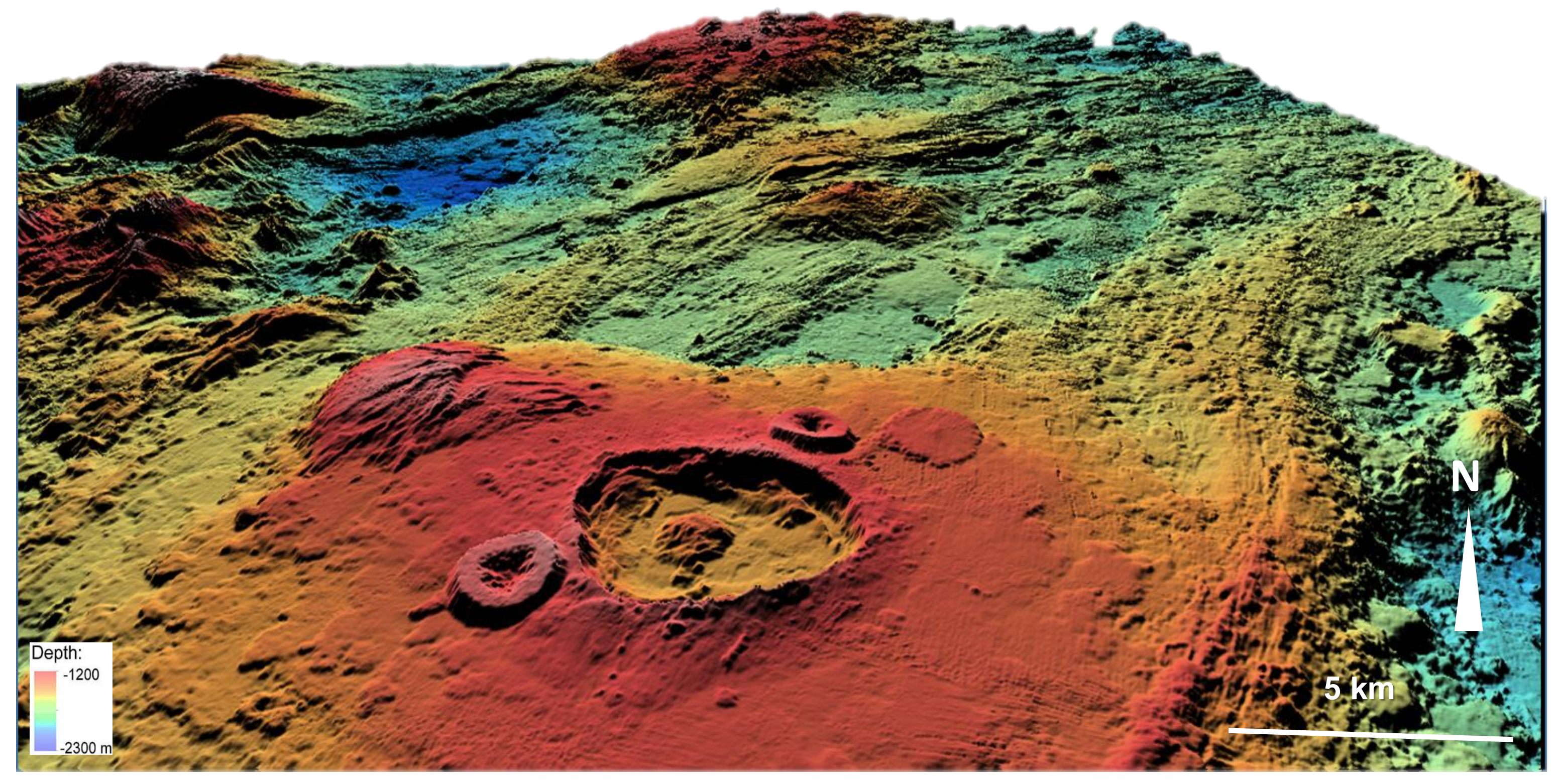




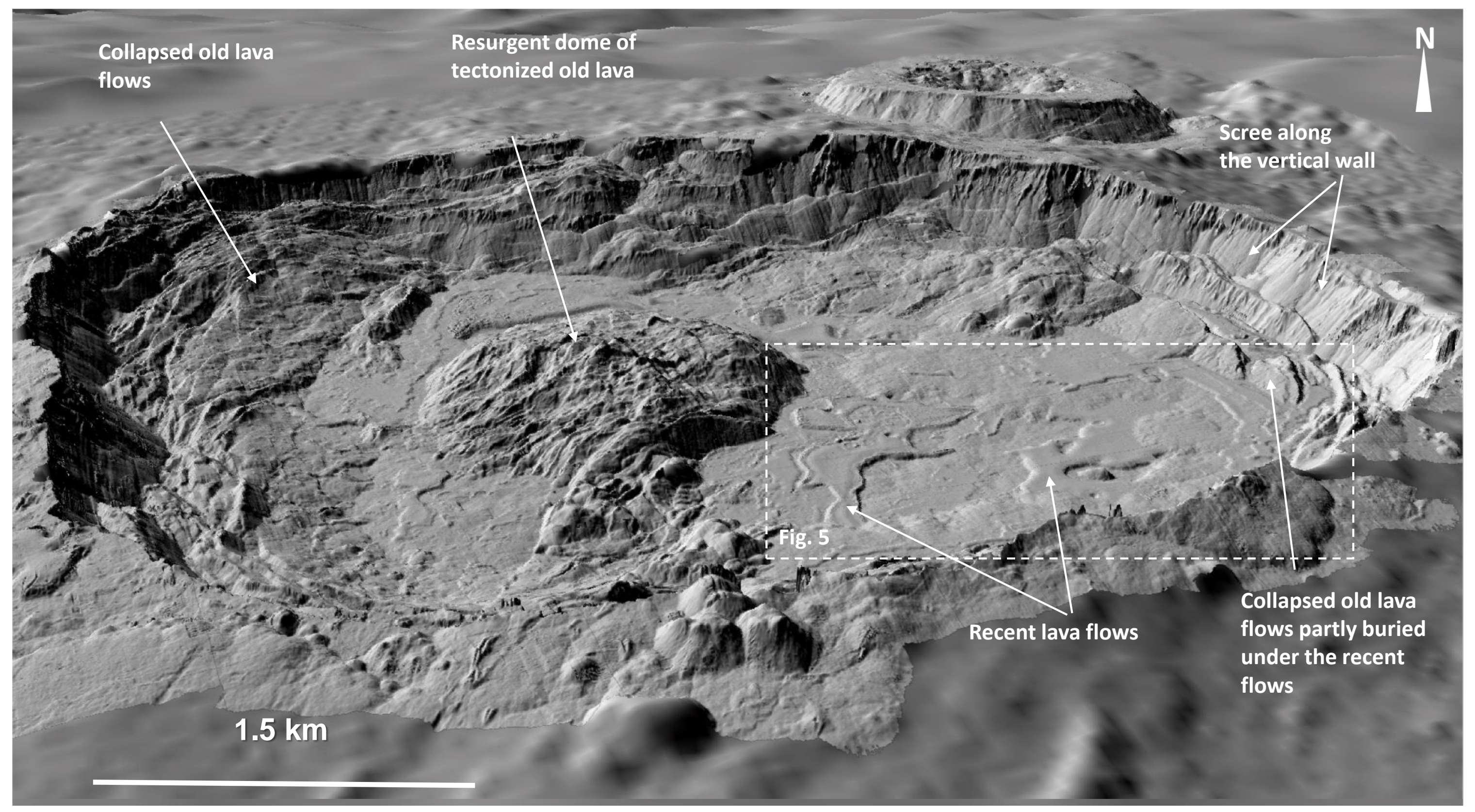




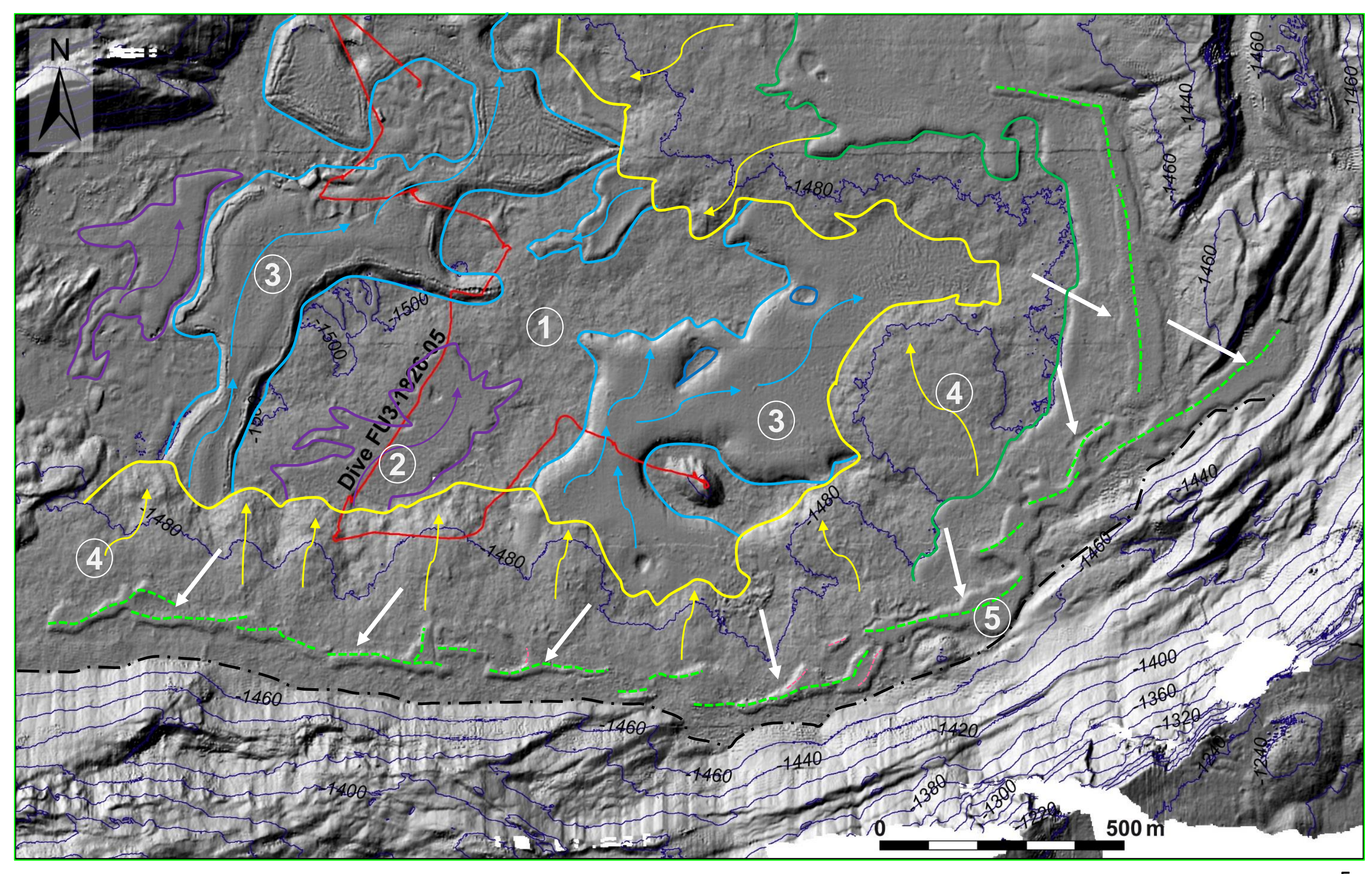

Figure 5 - in colors 


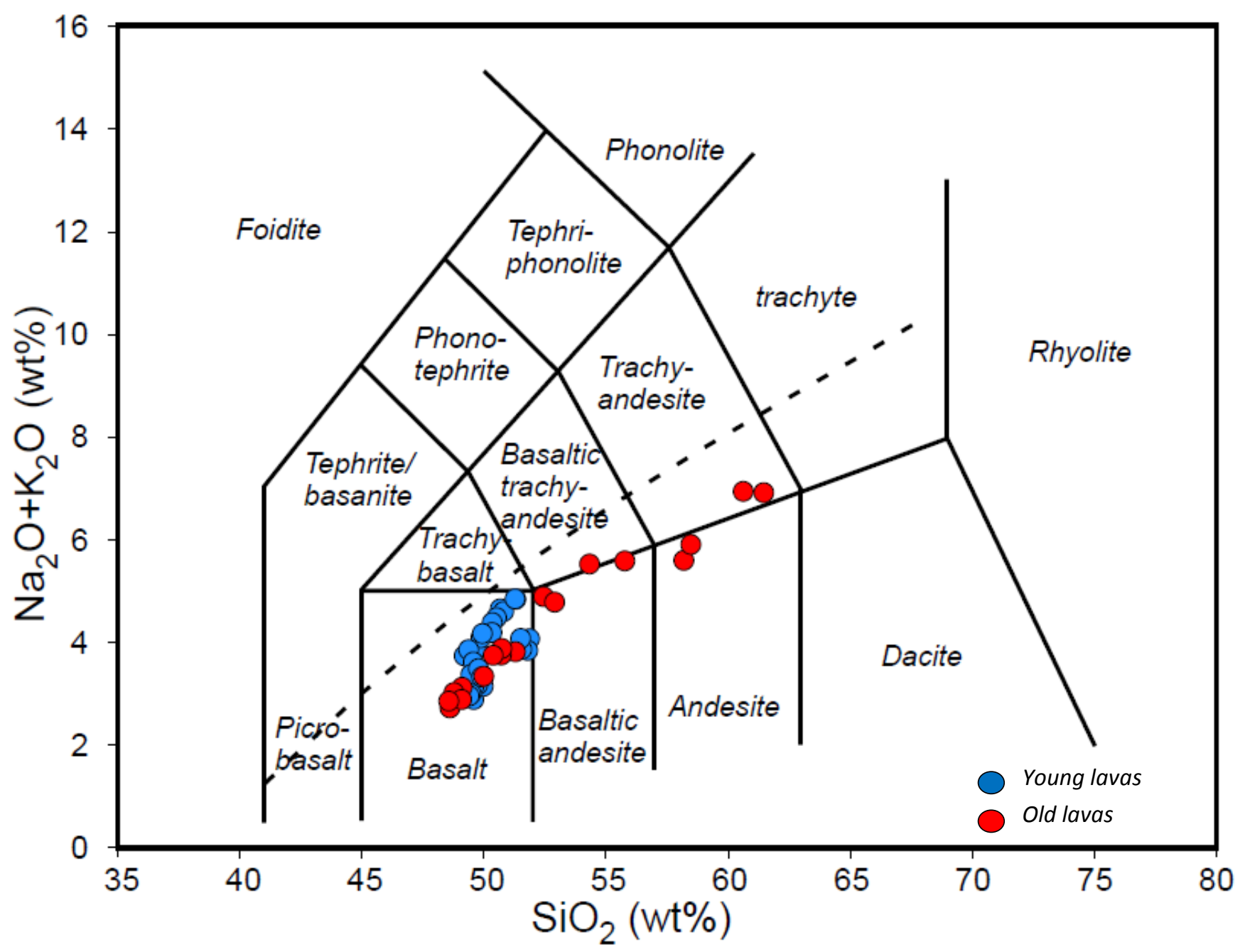

Figure 6 - in colors

Fouquet et al. ORGEO-2017-381 


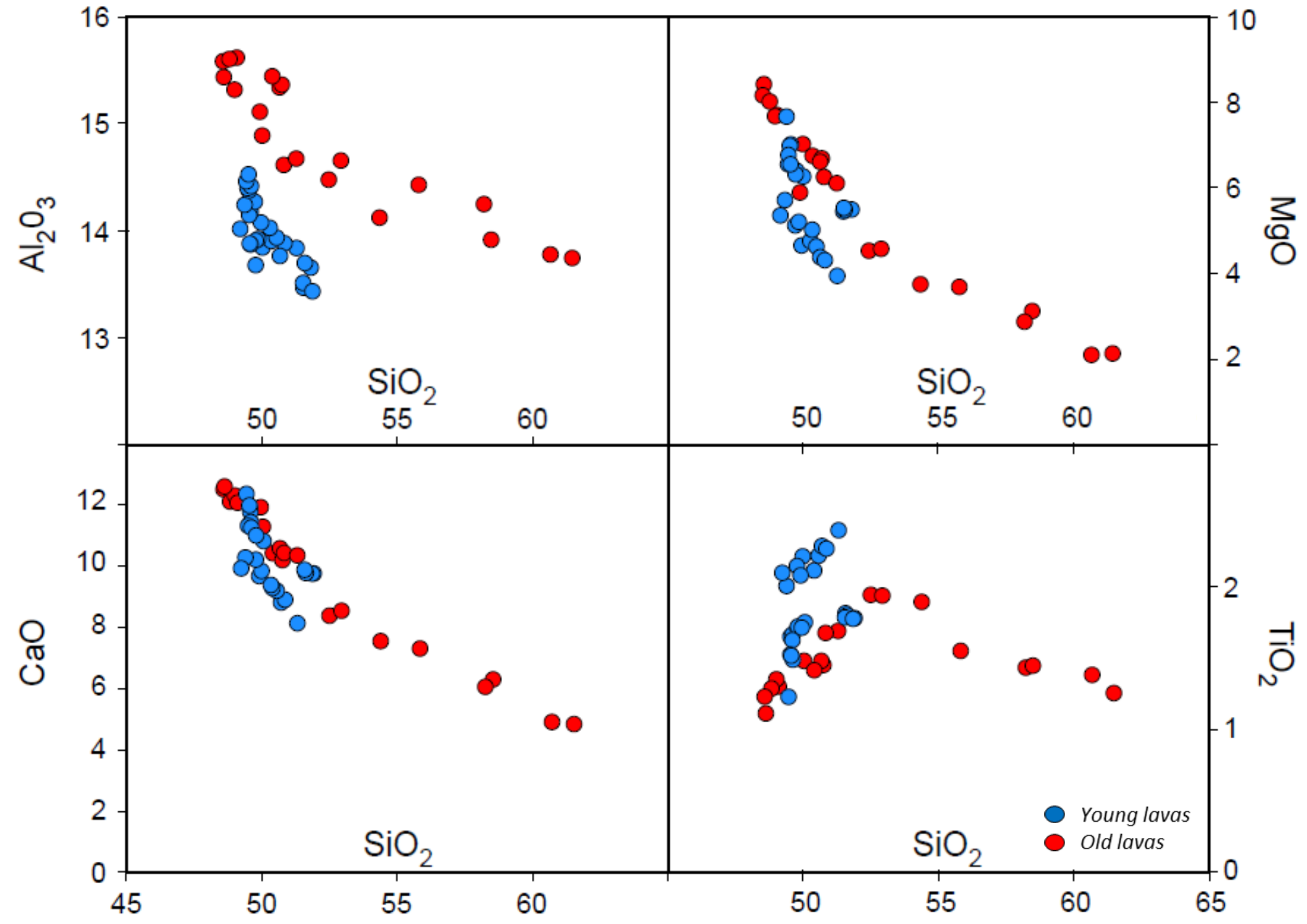

Figure 7 - in colors 


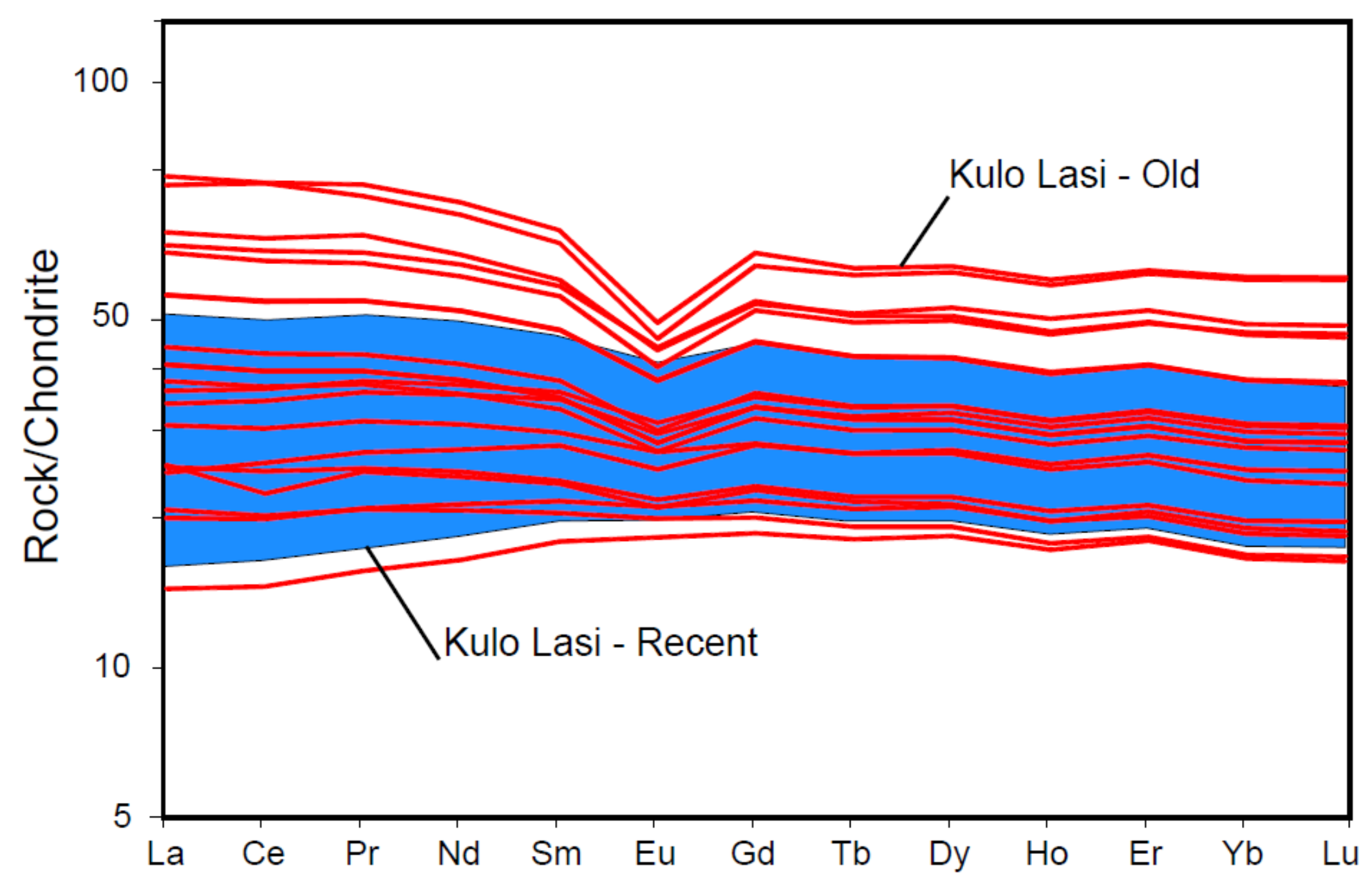

Figure 8 - in colors

Fouquet et al.

ORGEO-2017-381 


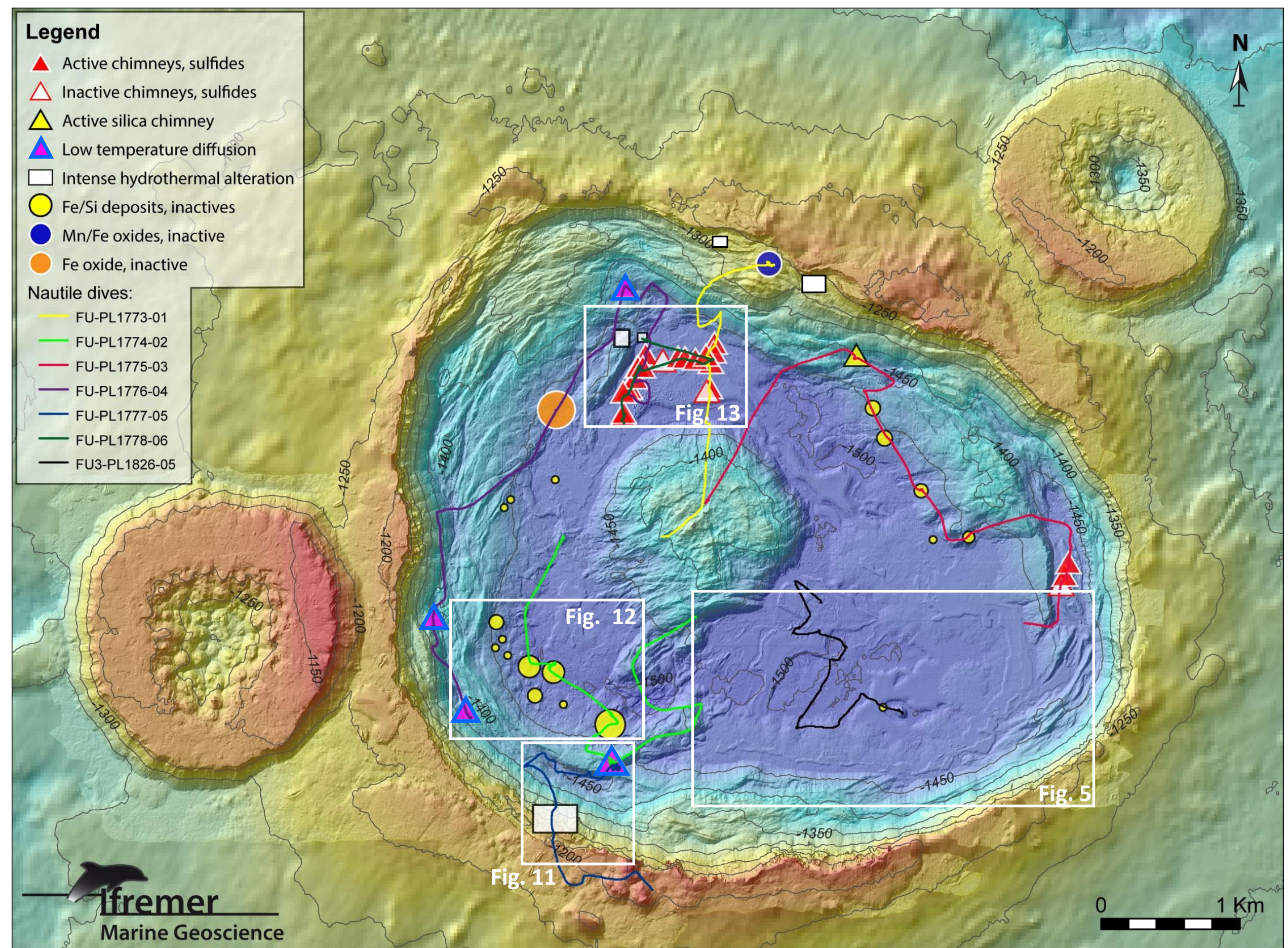

Figure 9 - in colors

Fouquet et al. ORGEO-2017-381 

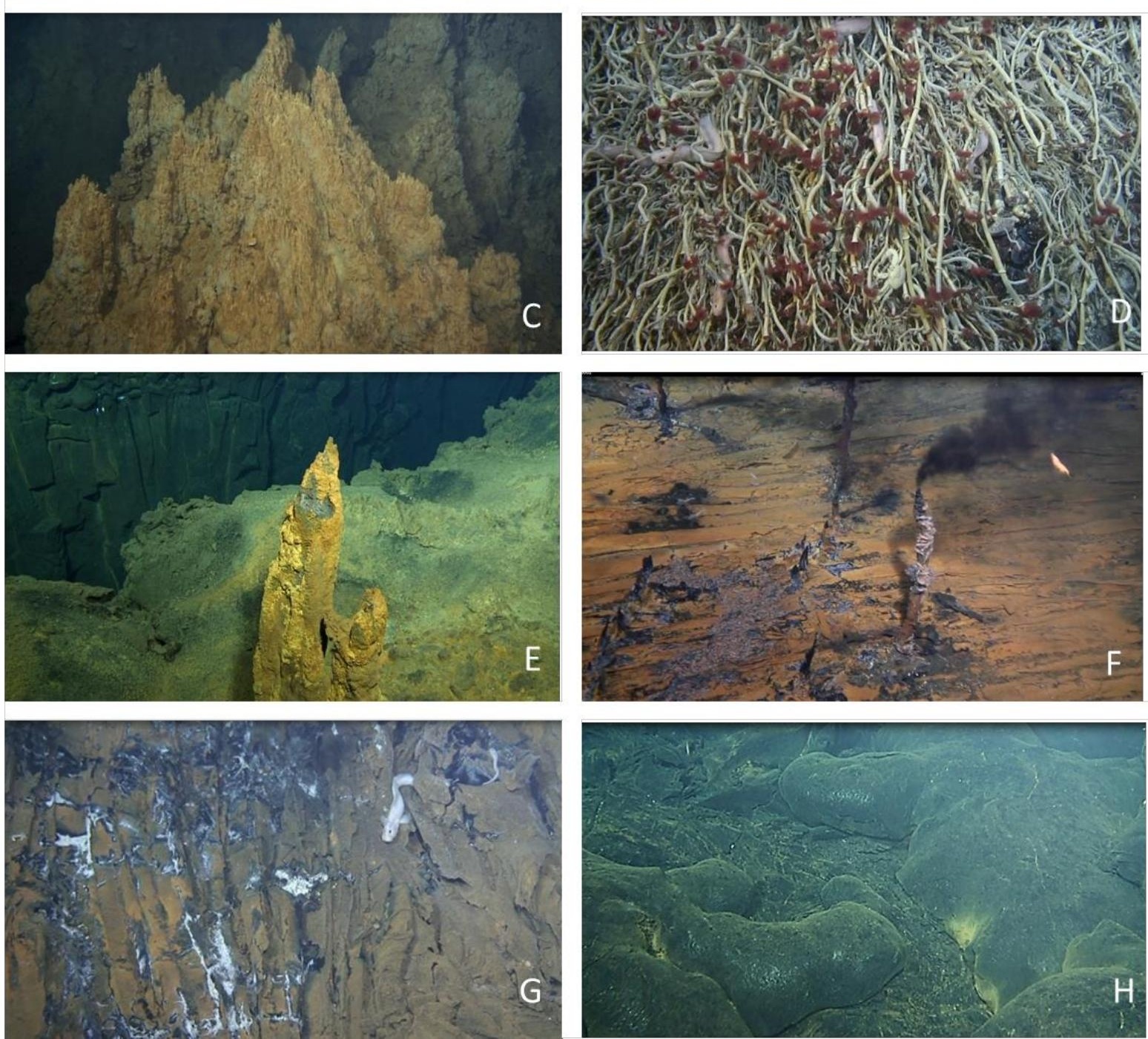

Figure 10 - in colors

Fouquet et al.

ORGEO-2017-381 


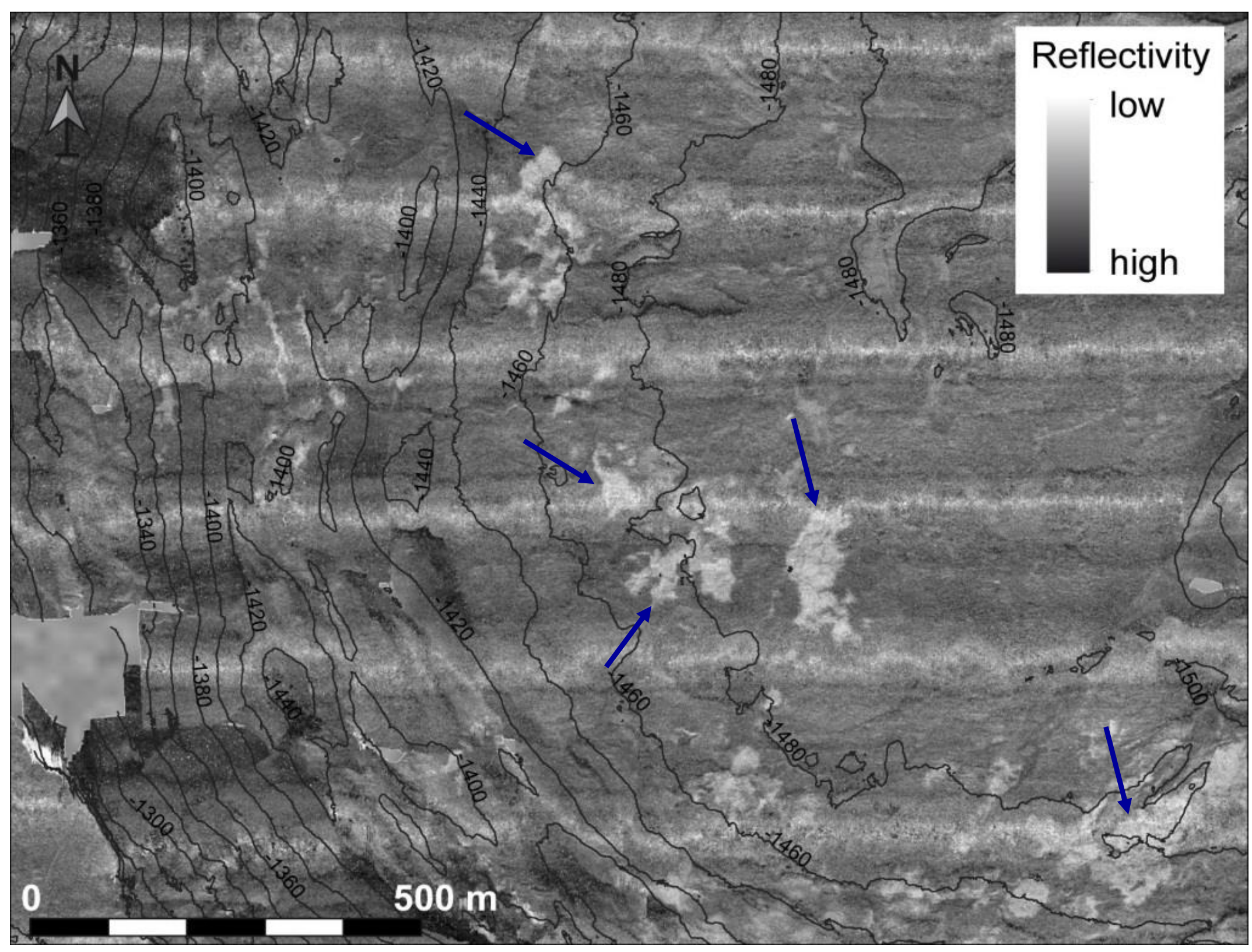

Figure 12 - in black and white

Fouquet et al.

ORGEO-2017-381 




Figure 14 - in colors

Fouquet et al.

ORGEO-2017-381 

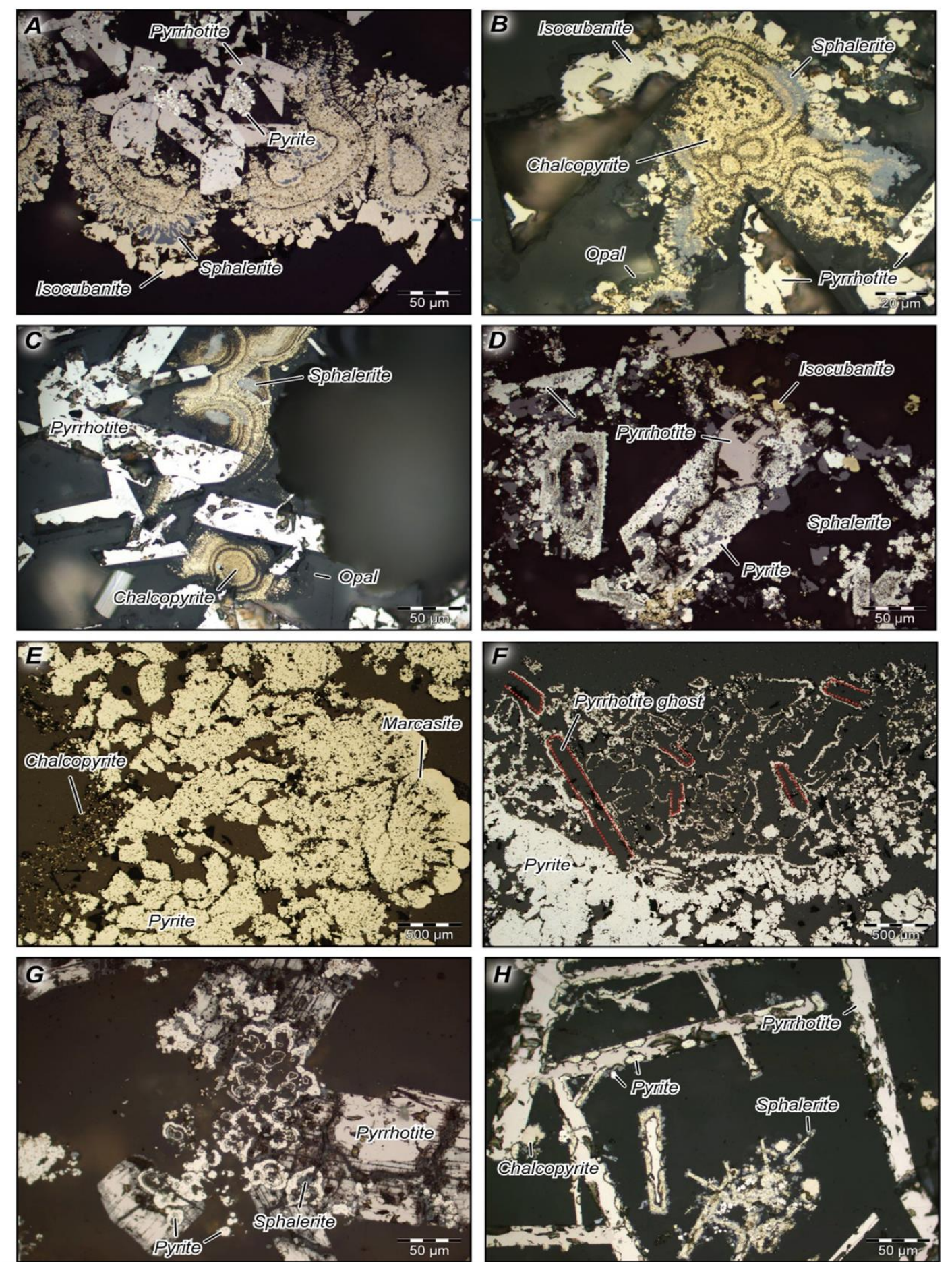

Figure 15 - in colors

Fouquet et al.

ORGEO-2017-381 

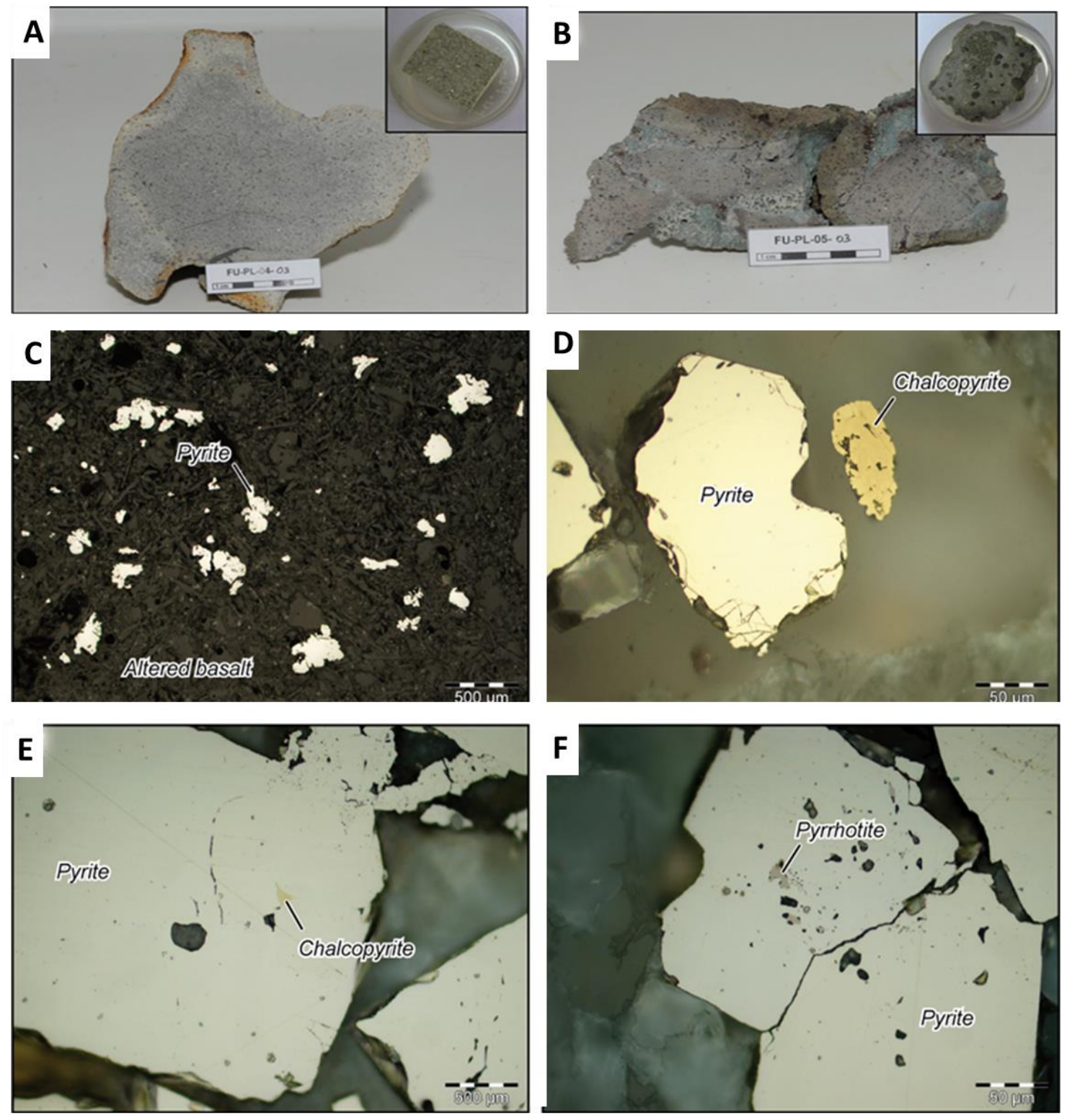

Figure 16 - in black and white

Fouquet et al.

ORGEO-2017-381 


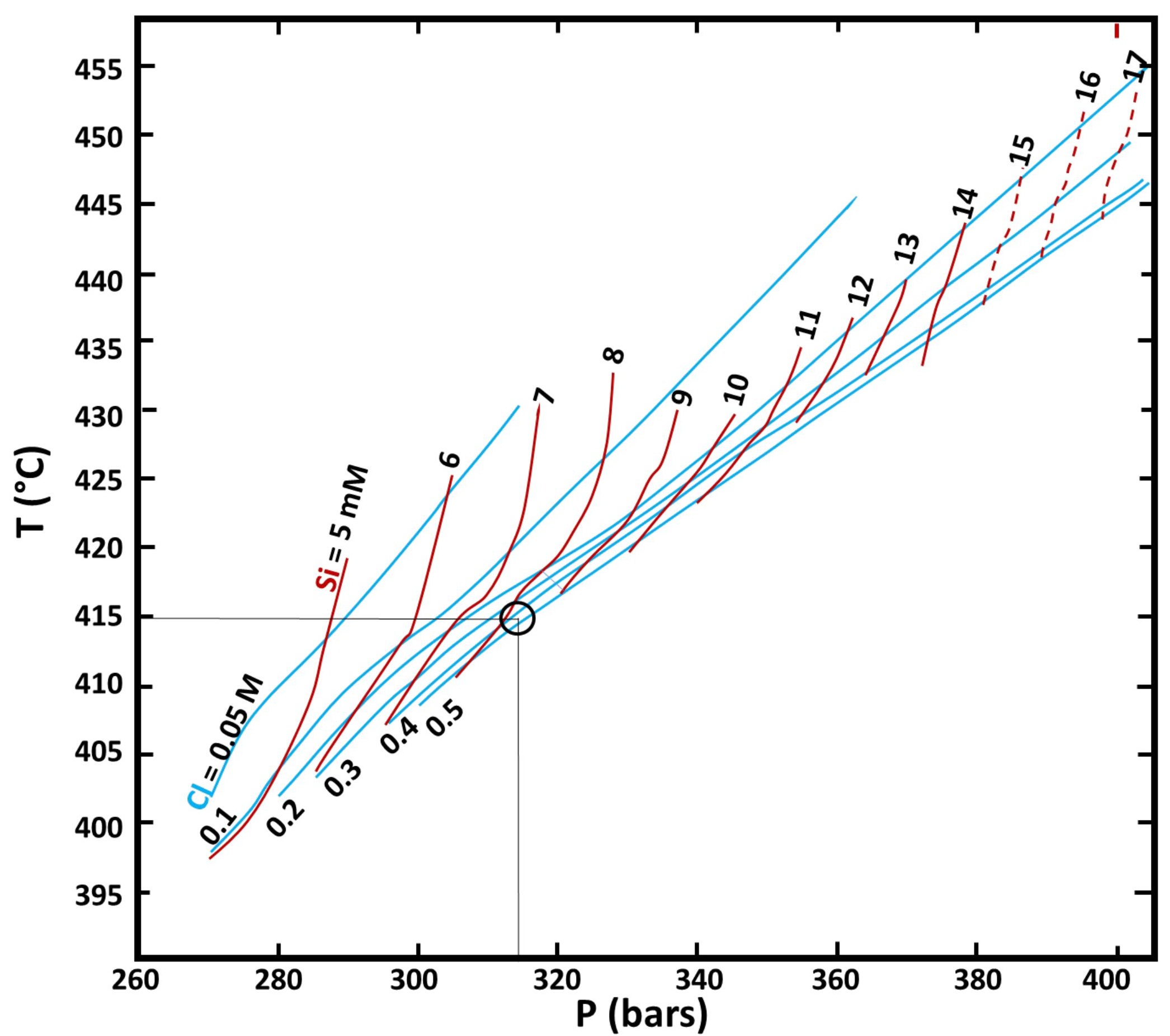

Figure 17 - in black and white

Fouquet et al.

ORGEO-2017-381 


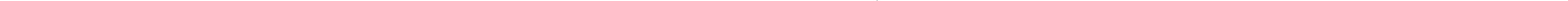




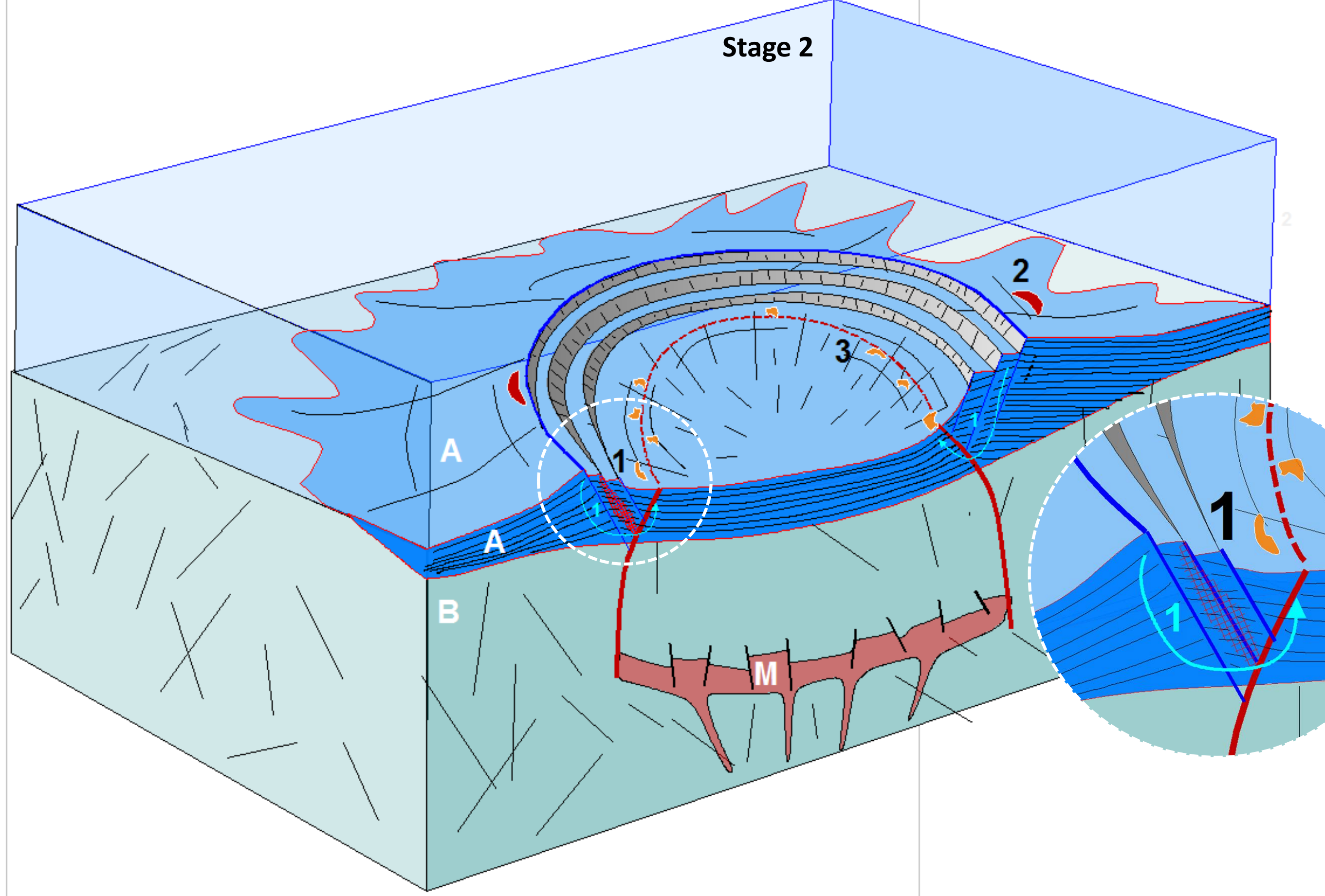

Figure 20 - in colors

Fouquet et al. ORGEO-2017-381 
Fouquet et al. ORGEO-2017-381

Tables 


\begin{tabular}{|c|c|c|c|c|c|c|}
\hline Name & $\begin{array}{c}\text { Geodynamic } \\
\text { Setting }\end{array}$ & Volcanim & $\begin{array}{c}\text { Diameter } \\
\text { Caldera }(\mathbf{k m}) \\
\end{array}$ & Mineralisation & $\begin{array}{c}\text { Temperature } \\
{ }^{\circ} \mathrm{C} \\
\end{array}$ & $\begin{array}{c}\text { Depth } \\
\text { m }\end{array}$ \\
\hline & Back-arc basins & & & & & \\
\hline 1 Bayonnaise & Izu Bonin & Andesite-dacite & $0.5 \times 0.7$ & Sulfides & - & $800-700$ \\
\hline 2 Desmos & Manus & Basalt-andesite & $1.5 \times 2$ & Sulfides/sulfur & 120 & 1810 \\
\hline 3 Niuatahi (Caldera O) & Lau & Dacite & 15 & Sulfides/sulfur & - & 1280 \\
\hline 4 CLSC A3 & Lau & Basalt-andesite & $?$ & Sulfides & - & 2500 \\
\hline 5 Palinuro & Tyrrhenian & Basalt-andesite & $11 \times 7$ & sulfides & - & $1000-650$ \\
\hline 6 Kulo Lasi & Futuna & Basalt-trachyandesite & $5.6 \times 4.5$ & Sulfide/silica/sulfur & 345 & $1200-1500$ \\
\hline 7 Southern caldera & NWLSC & Basalt & $1.5 \times 6$ & plume studies & - & 2160 \\
\hline 8 Central caldera & NWLSC & Basalt & $2.8 \times 7$ & plume studies & - & 2150 \\
\hline 9 Lobster caldera & Rochambeau Rift & Basalt & $2 \times 2.8$ & plume studies & - & 1500 \\
\hline 10 Dugong & North Lau Basin & Basalt & 5 & plume studies & - & 1170 \\
\hline \multirow[t]{2}{*}{11 Nifonea } & New Hebrides & Basalt & $5 \times 8$ & Sulfides & $\mathrm{HT}^{\circ}$ & $1875-2080$ \\
\hline & Arc volcanoes & & & & & \\
\hline 12 Myojin-Sunrise & Izu Bonin & Andesite-dacite-rhyolites & $6 \times 7$ & Sulfides & 278 & $1360-1220$ \\
\hline 13 Myojinsho & Izu Bonin & Andesite-dacite-rhyolites & $5 \times 6$ & Sulfides & - & $1110-850$ \\
\hline 14 Suyio & Izu Bonin & Andesite-dacite & 1.7 & Sulfides & 317 & $1380-1320$ \\
\hline 15 Kaikata & Izu Bonin & Andesite & 3 & Sulfides/manganese & 22 & $930-460$ \\
\hline 16 Toto & Mariana & $?$ & 13 & $?$ & 170 & $2960-2300$ \\
\hline 17 East Diamante & Mariana & Dacite & $5 \times 10$ & Barite/sulfides & 260 & $367-406$ \\
\hline 18 W Rota & Mariana & Andesite-rhyolite-basalt & $6 \times 10$ & feeder zone & - & 1500 \\
\hline 19 Fina Nagu Cone 5 & Mariana & Basalt-basaltic andesite & $?$ & Chimneys & $?$ & 2000 \\
\hline 20 Nikko & Mariana & Basalt-dacite & 0.36 & Sulfur & 215 & $410-490$ \\
\hline 21 Esmeralda & Mariana & Basalt-basaltic andesite & 4 & Sulfides/sulfur & 78 & 300 \\
\hline 22 Volcano 19 & Tonga & Basalt-basaltic andesite & 1.9 & Sulfides / barite & 265 & $970-385$ \\
\hline 23 Volcano 1 & Tonga & Basaltic andesite-andesite & $7 \times 4.5$ & Sulfure/Fe-oxides & 152 & 65 \\
\hline 24 Brothers & Kermadec & Basalt-andesite & $3 \times 3.5$ & Sulfides & 302 & $1800-1150$ \\
\hline 25 Healy & Kermadec & Basalt-felsic & $2 \times 2.5$ & plume studies & - & $1370-1140$ \\
\hline 26 Monowai & Kermadec & Basalt-basaltic andesite & 8 & Sulfides/sulfates & - & 1040 \\
\hline \multirow[t]{2}{*}{27 Kemp } & Sandwich & ? & $8 \times 7$ & White smokers & 40 & $800-1600$ \\
\hline & Mid-ocean ridges & & & & & \\
\hline 28 Axial seamount & Juan de Fuca & E-MORB & $3 \times 8$ & sulfides & 348 & 1540 \\
\hline 29 Los Huellos & Galapagos & MORB & $4 \times 2$ & sulfides & - & $1050-1530$ \\
\hline
\end{tabular}

Table 1

Fouquet et al.

ORGEO-2017-381 


\begin{tabular}{|c|c|c|c|c|c|}
\hline \multirow[t]{2}{*}{ Sample } & \multirow{2}{*}{$\begin{array}{l}\text { FU-DR-33-01gl } \\
\text { Basaltic trachy- } \\
\text { andesite }\end{array}$} & \multirow{2}{*}{$\begin{array}{l}\text { FU-DR-33-03 } \\
\begin{array}{l}\text { Old lava from } \\
\text { the caldera }\end{array} \\
\text { Trachy-andesite }\end{array}$} & \multirow{2}{*}{$\begin{array}{c}\text { FU-DR-38-01 } \\
\text { Basalt }\end{array}$} & \multicolumn{2}{|c|}{$\begin{array}{c}\text { FU-DR-36-02 FU-PL-03-06 } \\
\text { Young lava from surface } \\
\text { and caldera floor }\end{array}$} \\
\hline & & & & Basalt & Basalt \\
\hline \multicolumn{6}{|c|}{ 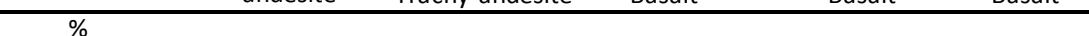 } \\
\hline $\mathrm{SiO2}$ & 53.6 & 60.1 & 48.6 & 49.2 & 51.3 \\
\hline $\mathrm{A} 1203$ & 13.9 & 13.4 & 15.4 & 14.4 & 13.8 \\
\hline $\mathrm{Fe} 2 \mathrm{O} 3$ & 12.0 & 8.9 & 10.8 & 11.6 & 15.0 \\
\hline $\mathrm{MgO}$ & 3.7 & 2.1 & 8.4 & 7.6 & 3.9 \\
\hline $\mathrm{CaO}$ & 7.4 & 4.7 & $\begin{array}{l}0.4 \\
12.6\end{array}$ & 12.3 & 8.1 \\
\hline $\mathrm{Na2O}$ & 4.7 & 5.4 & 2.6 & 2.7 & 4.1 \\
\hline $\mathrm{K} 2 \mathrm{O}$ & 0.7 & 1.3 & 0.2 & 0.2 & 0.7 \\
\hline TiO2 & 1.9 & 1.2 & 1.1 & 1.2 & 2.4 \\
\hline P205 & 0.4 & 0.3 & 0.1 & 0.1 & 0.4 \\
\hline $\mathrm{MnO}$ & 0.2 & 0.2 & 0.2 & 0.2 & 0.2 \\
\hline SO4 & 0.2 & 0.1 & 0.0 & 0.1 & 0.2 \\
\hline LOI & 0.2 & 1.1 & -0.3 & -0.3 & -0.1 \\
\hline total & 99.0 & 99.0 & 99.8 & 99.4 & 100.0 \\
\hline \multicolumn{6}{|l|}{$\mathrm{ppm}$} \\
\hline $\mathrm{V}$ & 258 & 61 & 255 & 285 & 340 \\
\hline Co & 40 & 17 & 44 & 45 & 42 \\
\hline $\mathrm{Ni}$ & 177 & 10 & 79 & 62 & 19 \\
\hline $\mathrm{Cu}$ & 92 & 38 & 170 & 171 & 89 \\
\hline $\mathrm{Zn}$ & 87 & 112 & 78 & 75 & 130 \\
\hline $\mathrm{Li}$ & 11 & 13 & 5 & 5 & 7 \\
\hline $\mathrm{Rb}$ & 16 & 27 & 2 & 3 & 11 \\
\hline $\mathrm{Sr}$ & 129 & 95 & 118 & 115 & 143 \\
\hline $\mathrm{Y}$ & 77 & 98 & 27 & 29 & 62 \\
\hline $\mathrm{zr}$ & 293 & 474 & 58 & 69 & 197 \\
\hline $\mathrm{Nb}$ & 18 & 26 & 4 & 4 & 12 \\
\hline Cs & 0.2 & 0.3 & 0.0 & 0.0 & 0.2 \\
\hline $\mathrm{Ba}$ & 138 & 216 & 39 & 33 & 113 \\
\hline La & 16.6 & 22.0 & 3.4 & 3.7 & 11.9 \\
\hline $\mathrm{Ce}$ & 41.6 & 56.8 & 8.8 & 9.9 & 30.2 \\
\hline $\mathrm{Pr}$ & 6.1 & $\begin{array}{l}7.6 \\
7.9\end{array}$ & $\begin{array}{l}1.0 \\
1.4\end{array}$ & 1.6 & 4.5 \\
\hline $\mathrm{Nd}$ & 29.3 & 36.8 & 7.5 & 8.3 & 22.3 \\
\hline Sm & 8.6 & 10.5 & 2.6 & 2.9 & 6.9 \\
\hline $\mathrm{Eu}$ & 2.5 & 2.6 & 1.0 & 1.1 & 2.3 \\
\hline Gd & $\begin{array}{l}2.0 \\
10.7\end{array}$ & 12.7 & 3.7 & 4.0 & 8.8 \\
\hline $\mathrm{Tb}$ & 1.9 & 2.2 & 0.7 & 0.7 & 1.5 \\
\hline Dy & 12.4 & $\begin{array}{l}2.2 \\
15.1\end{array}$ & 4.5 & 4.8 & 10.2 \\
\hline Ho & 2.6 & 3.3 & 1.0 & 1.0 & 2.2 \\
\hline $\mathrm{Er}$ & $\begin{array}{l}2.0 \\
7.9\end{array}$ & $\begin{array}{l}.5 \\
9.9\end{array}$ & 2.9 & 3.0 & 6.4 \\
\hline Yb & 7.6 & 9.8 & 2.7 & 2.8 & 6.0 \\
\hline Lu & $\begin{array}{l}1.0 \\
1.1\end{array}$ & $\begin{array}{l}1.0 \\
1.5\end{array}$ & 0.4 & 0.4 & $\begin{array}{l}0.0 \\
0.9\end{array}$ \\
\hline $\mathrm{Hf}$ & 7.3 & 11.3 & 1.8 & 2.0 & 5.1 \\
\hline $\mathrm{Ta}$ & 1.1 & 1.5 & $\begin{array}{l}0.0 \\
0.2\end{array}$ & 0.2 & $\begin{array}{l}.1 \\
0.8\end{array}$ \\
\hline $\mathrm{Pb}$ & 1.4 & 2.0 & 1.1 & 0.6 & 1.3 \\
\hline Th & 2.2 & $\begin{array}{l}3.0 \\
3.4\end{array}$ & 0.4 & 0.4 & 1.4 \\
\hline U & 0.7 & 1.2 & 0.1 & 0.1 & 0.5 \\
\hline
\end{tabular}

Table 2

Fouquet et al.

ORGEO-2017-381 


\begin{tabular}{|c|c|c|c|c|c|c|c|c|}
\hline $\begin{array}{l}\text { Zone } \\
\text { Sample name } \\
\text { Type } \\
\text { Color of the fluid } \\
\text { Depth }\end{array}$ & unit & $\begin{array}{c}\text { Sea Water } \\
\text { FU-PL-05-TiG2 }\end{array}$ & $\begin{array}{c}\mathrm{N} 1 \\
\text { FU-PL-06-TiG4 } \\
\text { Beehive } \\
\text { Black } \\
1475\end{array}$ & $\begin{array}{c}\mathrm{N} 1 \\
\text { FU-PL-06-TiD4 } \\
\text { Beehive } \\
\text { Black } \\
1475\end{array}$ & $\begin{array}{c}\text { N2 } \\
\text { FU-PL-06-TiG3 } \\
\text { Chimney } \\
\text { Clear } \\
1475\end{array}$ & $\begin{array}{c}\text { N2 } \\
\text { FU-PL-06-TiD3 } \\
\text { Chimney } \\
\text { Clear } \\
1475\end{array}$ & $\begin{array}{c}\text { N3 } \\
\text { FU-PL-06-TiD1 } \\
\text { Chimney } \\
\text { Black } \\
1475\end{array}$ & $\begin{array}{c}\text { N3 } \\
\text { FU-PL-06-TiG1 } \\
\text { Chimney } \\
\text { Black } \\
1475\end{array}$ \\
\hline \multicolumn{9}{|l|}{ Mesured concentrations } \\
\hline T chimney & ${ }^{\circ} \mathrm{C}$ & & 332 & 332 & 331 & 331 & 345 & 345 \\
\hline $\mathrm{pH}$ & & 7.8 & 6.07 & 5.58 & 2.24 & 2.37 & 2.36 & 3.32 \\
\hline $\mathrm{CH}_{4}$ & $\mathrm{mM}$ & 0 & - & 0.001 & 0.006 & & 0.004 & 0.001 \\
\hline $\mathrm{H}_{2}$ & $\mathrm{mM}$ & 0 & - & 1.14 & 19.83 & - & 6.18 & 1.04 \\
\hline $\mathrm{H}_{2} \mathrm{~S}$ & $\mathrm{mM}$ & 0 & 0.46 & 1.66 & 5.05 & 3.81 & 0.39 & - \\
\hline $\mathrm{CO}_{2}$ & $\mathrm{mM}$ & 2.3 & 2.6 & 1.3 & 5.1 & - & 3.0 & 1.0 \\
\hline $\mathrm{Cl}$ & $\mathrm{mM}$ & 551 & 516 & 485 & 497 & 517 & 735 & 689 \\
\hline $\mathrm{NaCl}$ & $w t \%$ & 3.2 & 3.0 & 2.8 & 2.9 & 3.0 & 4.3 & 4.0 \\
\hline Mg & $\mathrm{mM}$ & 53.2 & 49.8 & 45.7 & 24.6 & 28.6 & 26.5 & 34.9 \\
\hline $\mathrm{Si}$ & $\mathrm{mM}$ & 0.1 & 1.0 & 2.1 & 8.2 & 8.4 & 14.6 & 10.8 \\
\hline $\mathrm{Fe}$ & $\mu \mathrm{M}$ & 0 & 123 & 78 & 4796 & 4283 & 9884 & 6845 \\
\hline $\mathrm{Mn}$ & $\mu \mathrm{M}$ & 0 & 32 & 76 & 862 & 788 & 1416 & 1064 \\
\hline $\mathrm{Cu}$ & $\mu \mathrm{M}$ & 0 & 1.7 & 1.3 & 14.2 & 4.2 & 2.5 & 20.1 \\
\hline $\mathrm{Zn}$ & $\mu \mathrm{M}$ & 0 & 3.1 & 1.5 & 44.8 & 41.5 & 175.1 & 77.2 \\
\hline $\mathrm{SO}_{4}^{2-}$ & $\mathrm{mM}$ & 29 & 27 & 23.9 & 8.8 & 10.7 & 6.2 & 12 \\
\hline $\mathrm{Na}$ & $\mathrm{mM}$ & 457 & 448 & 406 & 388 & 405 & 612 & 565 \\
\hline K & $\mathrm{mM}$ & 9.8 & 10.6 & 9.5 & 18.5 & 16.6 & 29.5 & 23.7 \\
\hline $\mathrm{Ca}$ & $\mathrm{mM}$ & 10.6 & 10.5 & 10.2 & 11.6 & 10.8 & 10.9 & 10.8 \\
\hline $\mathrm{Li}$ & $\mu \mathrm{M}$ & 28 & 54 & 55 & 156 & 149 & 249 & 197 \\
\hline $\mathrm{Rb}$ & $\mu \mathrm{M}$ & 4.4 & 5.3 & 6.1 & 25.8 & 24.2 & 46.4 & 35.6 \\
\hline $\mathrm{Sr}$ & $\mu \mathrm{M}$ & 93 & 84.2 & 74 & 7.3 & 9.4 & 3.4 & 9.1 \\
\hline $\mathrm{Br}$ & $\mu \mathrm{M}$ & 833 & 822 & 994 & 738 & 770 & 1135 & 1051 \\
\hline $\mathrm{Fe} / \mathrm{Mn}$ & & - & 3.8 & 1.0 & 5.6 & 5.4 & 7.0 & 6.4 \\
\hline $\mathrm{Br} / \mathrm{Cl}$ & & & 1.59 & 2.05 & 1.48 & 1.49 & 1.54 & 1.53 \\
\hline \multicolumn{9}{|l|}{ Calculated end-members } \\
\hline $\mathrm{T}^{\circ}$ maximum measured & ${ }^{\circ} \mathrm{C}$ & & 134 & 136 & 342 & 338 & 343 & 343 \\
\hline $\mathrm{T}^{\circ}$ estimated using $\mathrm{Fe} / \mathrm{Mn}$ & ${ }^{\circ} \mathrm{C}$ & & 397 & 333 & 415 & 414 & 426 & 422 \\
\hline $\mathrm{T}^{\circ}$ calculated for heated & $:{ }^{\circ} \mathrm{C}$ & & - & - & 257 & 250 & 247 & 251 \\
\hline $\mathrm{Cl}$ & $\mathrm{mM}$ & & - & - & 451 & 477 & 918 & 952 \\
\hline $\mathrm{Si}$ & $\mathrm{mM}$ & & - & - & 15.2 & 18.0 & 29.0 & 31.2 \\
\hline $\mathrm{Fe}$ & $\mu \mathrm{M}$ & & - & - & 8921 & 9262 & 19694 & 19899 \\
\hline $\mathrm{Mn}$ & $\mu \mathrm{M}$ & & - & - & 1603 & 1704 & 2821 & 3093 \\
\hline $\mathrm{Cu}$ & $\mu \mathrm{M}$ & & - & - & 26 & 9 & 5 & 58 \\
\hline $\mathrm{Zn}$ & $\mu \mathrm{M}$ & & - & - & 83 & 90 & 349 & 224 \\
\hline $\mathrm{Na}$ & $\mathrm{mM}$ & & - & - & 329 & 345 & 766 & 771 \\
\hline K & $\mathrm{mM}$ & & - & - & 26 & 25 & 49 & 50 \\
\hline $\mathrm{Ca}$ & $\mathrm{mM}$ & & - & - & 12 & 11 & 11 & 11 \\
\hline $\mathrm{Li}$ & $\mu \mathrm{M}$ & & - & - & 266 & 290 & 468 & 519 \\
\hline $\mathrm{Rb}$ & $\mu \mathrm{M}$ & & - & - & 44 & 47 & 88 & 95 \\
\hline $\mathrm{Sr}$ & $\mu \mathrm{M}$ & & - & - & -66 & -88 & -86 & -151 \\
\hline $\mathrm{Br}$ & $\mu \mathrm{M}$ & & - & - & 656 & 697 & 1435 & 1467 \\
\hline
\end{tabular}

Table 3

Fouquet et al.

ORGEO-2017-381 


\begin{tabular}{|c|c|c|c|c|c|c|c|c|c|c|c|c|c|c|c|}
\hline \multirow{2}{*}{$\begin{array}{c}\text { Type } \\
\text { Location }\end{array}$} & \multicolumn{5}{|c|}{ Sulfate-rich } & \multicolumn{6}{|c|}{ Zn-rich sulfides } & \multicolumn{4}{|c|}{ Fe-rich sulfides } \\
\hline & NW & NW & NW & NW & NW & NW & $E$ & $E$ & $E$ & NW & $E$ & $E$ & NW & NW & $\mathrm{E}$ \\
\hline 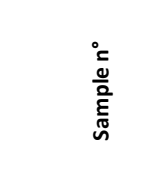 & 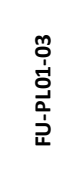 & 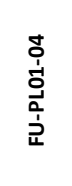 & 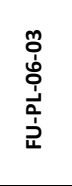 & 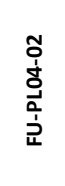 & 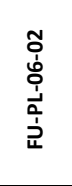 & 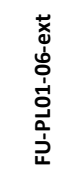 & 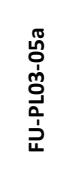 & 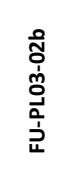 & 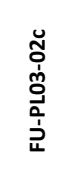 & 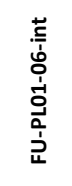 & 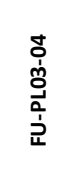 & 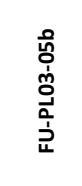 & 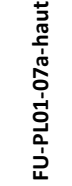 & 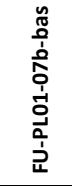 & 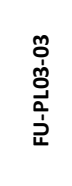 \\
\hline \multicolumn{16}{|l|}{$\%$} \\
\hline s & 26.18 & 25.57 & 26.20 & 25.44 & 26.38 & 32.56 & 32.01 & 33.12 & 33.85 & 37.09 & 39.92 & 40.17 & 39.35 & 33.32 & 46.49 \\
\hline $\mathrm{Ca}$ & 28.69 & 27.89 & 27.64 & 27.62 & 19.73 & 0.38 & 0.34 & $<0.3$ & $<0.3$ & $<0.3$ & 0.31 & $<0.3$ & $<0.3$ & $<0.3$ & 1.47 \\
\hline $\mathrm{Fe}$ & 3.64 & 1.48 & 1.25 & 1.31 & 13.76 & 9.90 & 11.10 & 35.50 & 36.95 & 46.94 & 39.50 & 58.76 & 55.07 & 44.72 & 42.32 \\
\hline $\mathrm{Cu}$ & 0.11 & $<0.1$ & $<0.1$ & $<0.1$ & 0.27 & 1.04 & 0.29 & 0.77 & 0.83 & 2.02 & 1.53 & 1.70 & 1.88 & 1.01 & 1.27 \\
\hline $\mathrm{Zn}$ & $<0.2$ & $<0.2$ & $<0.2$ & $<0.2$ & 0.21 & 47.70 & 43.47 & 13.20 & 11.84 & 8.67 & 7.56 & 2.78 & 2.63 & 1.50 & 1.11 \\
\hline $\mathrm{Pb}$ & & & & & & 1.46 & 1.53 & 0.47 & 0.33 & 0.35 & 0.29 & & & & \\
\hline Ва & $<0.2$ & $<0.2$ & $<0.2$ & $<0.2$ & $<0.2$ & 5.04 & 2.91 & 0.81 & $<0.2$ & 1.75 & 0.28 & $<0.2$ & $<0.2$ & 3.88 & 0.73 \\
\hline Al2O3 & 0.70 & 1.46 & 1.56 & 1.11 & 1.79 & 0.57 & 0.67 & 0.66 & 0.67 & 0.63 & 0.70 & 0.59 & 0.59 & 0.79 & 0.62 \\
\hline $\mathrm{SiO} 2$ & 0.32 & $<0.3$ & $<0.3$ & $<0.3$ & 5.76 & 2.15 & 6.53 & 8.91 & 16.32 & 3.15 & 10.94 & $<0.3$ & 2.22 & 12.72 & 2.23 \\
\hline $\mathrm{MgO}$ & $<0.3$ & $<0.3$ & 0.30 & $<0.3$ & 0.99 & $<0.3$ & 0.31 & $<0.3$ & $<0.3$ & $<0.3$ & $<0.3$ & $<0.3$ & $<0.3$ & $<0.3$ & 1.04 \\
\hline P205 & 0.03 & 0.04 & 0.05 & 0.04 & 0.06 & 0.04 & 0.06 & 0.04 & 0.03 & 0.03 & 0.07 & 0.03 & 0.03 & 0.03 & 0.07 \\
\hline K2O & $<0.01$ & 0.01 & 0.02 & $<0.01$ & 0.05 & 0.04 & 0.09 & 0.04 & 0.02 & 0.02 & 0.03 & 0.02 & 0.01 & 0.03 & $<0.01$ \\
\hline TiO2 & $<0.01$ & $<0.01$ & $<0.01$ & $<0.01$ & 0.18 & 0.03 & 0.02 & 0.04 & 0.01 & 0.01 & $<0.01$ & 0.01 & 0.01 & 0.02 & $<0.01$ \\
\hline $\mathrm{MnO}$ & 0.11 & $<0.01$ & $<0.01$ & $<0.01$ & 0.03 & 0.10 & 0.35 & 0.05 & 0.02 & 0.09 & 0.04 & 0.03 & 0.02 & 0.02 & 0.04 \\
\hline \multicolumn{16}{|l|}{$\mathrm{ppm}$} \\
\hline Mo & & 17 & $<10$ & 17 & 23 & 64 & 62 & 37 & 32 & 36 & 63 & 22 & 56 & 154 & 65 \\
\hline $\mathrm{Sr}$ & 1800 & 2851 & 1717 & 1688 & 1943 & 1121 & 560 & 188 & 28 & 409 & 15 & 11 & 9 & 1130 & 502 \\
\hline $\mathrm{Pb}$ & 35 & 12 & 15 & 27 & 51 & 14892 & 17042 & 3949 & 2495 & 2902 & 2121 & 392 & 501 & 767 & 40 \\
\hline As & 10 & 6 & $<5$ & $<5$ & 240 & 780 & 1724 & 532 & 551 & 920 & 1161 & 558 & 1525 & 126 & 57 \\
\hline Se & & 10 & $<5$ & $<5$ & 256 & 33 & $<5$ & 207 & 132 & 501 & 489 & 812 & 483 & 867 & 370 \\
\hline Ga & & $<5$ & $<5$ & $<5$ & 7 & 45 & 734 & 157 & 145 & 15 & 107 & 49 & 20 & $<5$ & $<5$ \\
\hline Ge & & $<10$ & $<10$ & $<10$ & $<10$ & 160 & 324 & 59 & 38 & 14 & 26 & $<10$ & $<10$ & $<10$ & $<10$ \\
\hline U & & $<5$ & $<5$ & $<5$ & $<5$ & $<5$ & $<5$ & $<5$ & 6 & $<5$ & 13 & 6 & 6 & $<5$ & 9 \\
\hline Co & $<10$ & $<10$ & 80 & 52 & 938 & 754 & 1311 & 1075 & 749 & 2254 & 2471 & 2649 & 2664 & 1703 & 1077 \\
\hline $\mathrm{Ni}$ & 13 & $<10$ & $<10$ & $<10$ & 32 & 157 & 128 & 26 & 22 & 25 & 82 & $<10$ & 22 & 35 & 77 \\
\hline $\mathrm{Ag}$ & & $<20$ & $<20$ & $<20$ & $<20$ & 298 & 232 & 68 & 62 & 43 & 26 & $<20$ & $<20$ & $<20$ & $<20$ \\
\hline $\mathrm{Cd}$ & & $<15$ & $<15$ & $<15$ & $<15$ & 2482 & 1829 & 635 & 576 & 455 & 367 & 151 & 178 & 84 & 60 \\
\hline In & & $<10$ & $<10$ & $<10$ & $<10$ & 47 & 30 & 12 & 11 & 26 & 13 & 18 & 10 & 48 & 18 \\
\hline Sn & & $<20$ & $<20$ & $<20$ & $<20$ & 694 & 652 & 311 & 348 & 156 & 240 & 106 & 68 & 42 & $<20$ \\
\hline $\mathrm{Sb}$ & & $<20$ & $<20$ & $<20$ & $<20$ & 77 & 215 & 93 & 120 & 37 & 86 & 22 & 34 & $<20$ & $<20$ \\
\hline $\mathrm{Au}$ & & 0.3 & 0.4 & 0.3 & 0.6 & $<2$ & $<2$ & $<2$ & $<2$ & $<2$ & $<2$ & $<2$ & $<2$ & 0.9 & 0.7 \\
\hline w & & $<0.3$ & $<0.3$ & $<0.3$ & $<0.3$ & & & & & & & $>0.8$ & & $>0.7$ & $>0.4$ \\
\hline $\mathrm{Pt}$ & & $<0.2$ & $<0.2$ & $<0.2$ & $<0.2$ & $<0.2$ & $<0.2$ & $<0.2$ & $<0.2$ & $<0.2$ & $<0.2$ & $<0.2$ & $<0.2$ & $<0.2$ & $<0.2$ \\
\hline & & $<1$ & $<1$ & 1.9 & 2.6 & $<1$ & $<1$ & $<1$ & $<1$ & $<1$ & 3.3 & $<1$ & 4.9 & 10.6 & $<1$ \\
\hline \multicolumn{16}{|c|}{ Mineral composition } \\
\hline Pyrrhotite & & & & & 18 & 8 & & 47 & 40 & 51 & 14 & 84 & 70 & 61 & 7 \\
\hline \multicolumn{2}{|c|}{ Sphalerite/wurtzite } & & & & & 69 & 67 & 28 & 27 & 16 & 20 & 7 & 7 & 3 & 2 \\
\hline \multirow{2}{*}{\multicolumn{2}{|c|}{ Pyrite }} & 1 & $<1$ & $<1$ & 3 & 1 & 6 & 6 & 9 & 2 & 43 & & 1 & 4 & 50 \\
\hline Chalcopyrite & & & & & & 6 & 8 & 7 & 8 & 15 & 10 & 8 & 14 & 7 & 13 \\
\hline Isocubanite & & & & & & $<1$ & 0 & $<1$ & $<1$ & 3 & $<1$ & $<1$ & 4 & 1 & $<1$ \\
\hline \multicolumn{2}{|l|}{ Marcasite } & & & & & & & & & & & & & & 21 \\
\hline \multirow{2}{*}{\multicolumn{2}{|c|}{$\begin{array}{l}\text { Barite } \\
\text { Anhydrite }\end{array}$}} & & & & & 14 & 8 & 4 & & 6 & 2 & 0 & 2 & 13 & 4 \\
\hline & & 99 & 99 & 99 & 74 & $<1$ & & & & & & & & & \\
\hline \multicolumn{2}{|l|}{$\begin{array}{l}\text { Halite } \\
\text { Nontronite }\end{array}$} & & & & & & 6 & & & & & & & & 1 \\
\hline $\begin{array}{l}\text { Nontronite } \\
\text { Opal }\end{array}$ & & $<0.3$ & $<0.3$ & $<0.3$ & 6 & 2 & 7 & 9 & 16 & 3 & 11 & $<0.3$ & 2 & 13 & 2 \\
\hline
\end{tabular}

Table 4

Fouquet et al.

ORGEO-2017-381 


\section{Table 5}

\begin{tabular}{|c|c|c|c|c|c|c|c|c|c|c|c|c|c|c|c|c|c|c|c|c|c|c|c|}
\hline Name & Host Rocks & Regional setting & $n$ & depth $(m)$ & $\mathrm{Cu}$ & $\mathrm{Zn}$ & $\mathrm{Pb}$ & $\begin{array}{c}\mathrm{Fe} \\
(\mathrm{wt} \%)\end{array}$ & $s$ & $\mathrm{SiO2}$ & $\mathrm{Ba}$ & $\mathrm{Ag}$ & $\mathrm{Au}$ & $\mathrm{Cd}$ & As & Sb & $\begin{array}{r}\mathrm{Ni} \\
(\mathrm{ppm})\end{array}$ & Co & Se & Mo & $\ln$ & Sn & references \\
\hline \multicolumn{24}{|c|}{ Fast-spreading mid-ocean ridges } \\
\hline $13^{\circ} \mathrm{N}$ & MORB & East Pacific Rise & 31 & 2650 & 4.56 & 15.26 & 0.09 & 25.48 & 36.54 & 2.21 & 0.00 & 88 & 0.56 & 436 & 210 & 3 & 2 & 408 & 96 & 48 & $<5$ & $<10$ & 1 \\
\hline $17^{\circ} 30 \mathrm{~S}$ & MORB & East Pacific Rise & 28 & 2573 & 2.65 & 11.99 & 0.05 & 32.76 & 41.57 & 4.14 & 0.00 & 44 & 0.10 & 302 & 211 & 3 & 1 & 218 & 263 & 63 & 4 & 3 & 2 \\
\hline $18^{\circ} 30 \mathrm{~S}$ & MORB & East Pacific Rise & 18 & 2640 & 10.19 & 8.54 & 0.04 & 31.28 & 46.89 & 2.05 & 0.03 & 55 & 0.32 & 273 & 141 & 15 & 24 & 1321 & 243 & 197 & 9 & 8 & 3 \\
\hline $21^{\circ} 30 \mathrm{~S}$ & MORB & East Pacific Rise & 26 & 2820 & 9.90 & 4.10 & 0.06 & 37.50 & 22.99 & 4.04 & 0.01 & 62 & 0.42 & 220 & 31 & 1 & 219 & 1185 & - & 90 & - & - & 4 \\
\hline \multicolumn{24}{|c|}{ Slow-spreading mid-ocean ridges } \\
\hline Menez Gwen & E-MORB & Mid Atlantic Ridge & 26 & 820 & 1.75 & 1.66 & 0.05 & 7.12 & 14.25 & 25.99 & 20.77 & 27 & 0.15 & 100 & 114 & 30 & 22 & 18 & 63 & 55 & - & - & 5 \\
\hline Lucky Strike & E-MORB & Mid Atlantic Ridge & 154 & 1650 & 5.37 & 4.16 & 0.05 & 21.05 & 30.97 & 12.38 & 10.85 & 74 & 0.30 & 195 & 334 & 28 & 10 & 89 & 110 & 79 & 1 & 1 & 6 \\
\hline TAG & MORB & Mid Atlantic Ridge & 66 & 3670 & 8.34 & 7.63 & 0.04 & 25.13 & 26.56 & 8.89 & 0.01 & 81 & 1.40 & 203 & 98 & 15 & 68 & 95 & 30 & 84 & & 2 & 7 \\
\hline Snake Pit & MORB & Mid Atlantic Ridge & 71 & 3500 & 8.26 & 6.10 & 0.05 & 36.95 & 36.03 & 3.00 & & 80 & 1.79 & 242 & 312 & 27 & 1 & 135 & 135 & 60 & 4 & 25 & 8 \\
\hline Krasnov & MORB & Mid Atlantic Ridge & 16 & 3700 & 2.21 & 0.14 & 0.01 & 38.96 & 42.90 & 11.21 & 0.27 & 18 & 1.10 & 19 & 66 & 20 & 15 & 628 & 23 & 88 & 10 & 23 & 9 \\
\hline Rainbow & Ultramafic rocks +- gabbros & Mid Atlantic Ridge & 116 & 2400 & 12.43 & 14.99 & 0.03 & 28.56 & 32.75 & 0.71 & 0.29 & 188 & 5.10 & 391 & 214 & 34 & 490 & 5086 & 186 & 29 & 10 & 138 & 10 \\
\hline Achadze-1 & Ultramafic rocks +- gabbros & Mid Atlantic Ridge & 49 & 4100 & 14.21 & 14.11 & 0.03 & 32.81 & 31.74 & 1.30 & 0.05 & 79 & 6.30 & 251 & 231 & 29 & 973 & 2882 & 200 & 31 & 11 & 347 & 11 \\
\hline logatchev-1 & Ultramafic rocks +- gabbros & Mid Atlantic Ridge & 18 & 3000 & 28.03 & 3.82 & 0.02 & 28.60 & 32.44 & 2.83 & 0.08 & 45 & 6.50 & 94 & 65 & 26 & 92 & 654 & 772 & 23 & 14 & 249 & 12 \\
\hline \multicolumn{24}{|l|}{ Back-arc basins } \\
\hline Central Manus & MORB, minor $B A B B$ & Central Manus basin & 152 & 2500 & 1.00 & 17.60 & 0.60 & 11.60 & 24.50 & 24.20 & 8.70 & 514 & - & 500 & 425 & - & 19 & 24 & - & - & $<20$ & - & 13 \\
\hline Vienne Wood & MORB, minor $B A B B$ & Central Manus basin & 18 & 2500 & 1.04 & 21.07 & 0.21 & 6.46 & 26.19 & 13.40 & 2.20 & 114 & 3.00 & 929 & 156 & 29 & $<20$ & $<10$ & 7 & 82 & $<5$ & $<10$ & 14 \\
\hline North Fiji & MORB, E-MORB, minor BABB & North fiji basin & 26 & 1950 & 7.16 & 6.38 & 0.05 & 30.05 & 36.67 & 16.24 & 0.70 & 145 & 0.83 & 180 & 175 & 18 & 4 & 156 & 162 & 270 & $<5$ & $<10$ & 15 \\
\hline Central Mariana trough $18^{\circ} \mathrm{N}$ & MORB, minor $B A B B$ & Marianne trough & 11 & 3675 & 1.20 & 10.00 & 7.40 & 2.40 & 17.80 & 1.20 & 33.30 & 185 & 0.78 & 465 & 125 & 190 & - & 2 & 10 & 5 & - & - & 16 \\
\hline Kings Triple Junction & BABB, MORB, low $\mathrm{K}$ andesite & Northern Lau basin & 78 & 2000 & 5.60 & 28.20 & 0.10 & 8.70 & - & 14.40 & - & 17 & - & 555 & 380 & & 5 & 27 & - & - & 53 & - & 17 \\
\hline Kulo Lasi & MORB, trachy-andesite & Futuna volcanic area & 16 & 1500 & 0.80 & 8.97 & 0.29 & 26.71 & 32.21 & 6.36 & 1.00 & 46 & $<1$ & 433 & 531 & 44 & 41 & 1121 & 265 & 42 & 15 & 168 & 18 \\
\hline Pacmanus & BABB, MORB, low $\mathrm{K}$ andesite, dacite & Eastern Manus basin & 111 & 1650 & 6.40 & 24.80 & 1.40 & 12.40 & 24.70 & 10.80 & 6.40 & 290 & 13.49 & 960 & 4600 & 670 & 7 & 7 & 10 & 97 & 57 & 9 & 19 \\
\hline SuSu & BABB, MORB, low $K$ andesite, dacite & Eastern Manus basin & 19 & 1460 & 14.20 & 1.10 & 0.20 & 20.80 & 29.70 & 14.10 & 5.30 & 97 & 14.52 & 92 & 7890 & 385 & - & 118 & 39 & 470 & - & - & 20 \\
\hline Vai Lili & BABB, MORB, low $K$ andesite, dacite & Southern Lau basin & 24 & 1710 & 7.52 & 20.65 & 0.21 & 10.15 & 28.13 & 4.41 & 9.02 & 113 & 1.21 & 566 & 1213 & 29 & 9 & 1 & 1 & 24 & 73 & 6 & 21 \\
\hline White Church & BABB, MORB, low $K$ andesite, dacite & Southern Lau basin & 21 & 1966 & 3.80 & 11.09 & 0.38 & 7.06 & 18.83 & 21.62 & 23.98 & 109 & 2.26 & 318 & 430 & 85 & 2 & 2 & 2 & 53 & 1 & 0 & 22 \\
\hline Northern Valu Fa Ridge & BABB, MORB, low $K$ andesite, dacite & Southern Lau basin & 63 & 1850 & 3.20 & 12.10 & 0.40 & 6.80 & 18.10 & 21.30 & 21.80 & 86 & 2.68 & 300 & 450 & 78 & 22 & 3 & $<5$ & 36 & 11 & 8 & 23 \\
\hline Central Valu Fa Ridge & BABB, MORB, low $K$ andesite, dacite & Southern Lau basin & 87 & 1750 & 5.50 & 27.60 & 0.30 & 7.40 & 27.40 & 3.80 & 10.80 & 120 & 3.21 & 855 & 1900 & 76 & 13 & 3 & $<5$ & 16 & 125 & 19 & 24 \\
\hline Southern Valu Fa Ridge & BABB, MORB, low $K$ andesite, dacite & Southern Lau basin & 25 & 1850 & 1.70 & 11.60 & 0.70 & 32.30 & 38.90 & 1.80 & 3.30 & 405 & 1.43 & 350 & 3815 & 21 & 28 & 23 & 35 & 18 & 1 & 11 & 25 \\
\hline \multicolumn{24}{|l|}{ Arc } \\
\hline Myojin knoll & IAB, low $K$ andesite, dacite, Rhyolite & Izu-Bonin arc & 37 & 1300 & 5.50 & 21.90 & 2.30 & 10.50 & - & 8.70 & 6.70 & 1215 & 20 & 1860 & 5045 & 3565 & - & - & - & - & - & - & 26 \\
\hline Suiyo Seamount & $I A B$, low $K$ andesite, dacite & Izu-Bonin arc & 13 & 1300 & 12.80 & 17.50 & 0.70 & 15.00 & - & - & $<0.1$ & 160 & 27.73 & 885 & 1170 & 585 & 4 & 19 & 1 & 120 & - & 15 & 27 \\
\hline Brothers & $I A B$, minor $B A B B$, med. $K$ andesite & Kermadec arc & 9 & 1600 & 2.80 & 3.30 & 0.20 & 7.40 & - & - & 31.90 & - & - & 105 & 2155 & & 66 & 39 & - & - & - & - & 28 \\
\hline \multicolumn{24}{|l|}{ Intracontinental back-arc } \\
\hline Jade site - Izena cauldron & Basalt, $K$ andesite, dacite, rhyolite, sediments & Central Okinawa trough & 40 & 1400 & 3.30 & 20.20 & 11.80 & 6.20 & 18.10 & 10.10 & 7.20 & 2305 & 3.13 & 820 & 17500 & 6710 & - & - & 4205 & - & - & - & 29 \\
\hline
\end{tabular}

Jade site - Izena cauldron Source of data: $(1)=$ Fouquet et al. $1996 ;(2,3,4,14)=$ Fouquet, unpublished data; $(5$ to 12$)=$ Fouquet et al., $2010 ;(13,16,17,19,20,23$
Fouquet et al., 1993. MORB = mid-ocean ridge basalt, E-MORB = enriched MORB; BABB = back-arc basin basalt; IAB = Island-arc tholeite. 
Table 6

\begin{tabular}{llll} 
FU-PL02-07 & FU-PL02-08 & FU-PL02-09 & FU-PL02-11 \\
\hline
\end{tabular}

\begin{tabular}{lrrrr}
\hline$\%$ & & & & \\
$\mathrm{SiO}_{2}$ & 86.53 & 43.80 & 42.83 & 26.26 \\
$\mathrm{Al}_{2} \mathrm{O}_{3}$ & 0.30 & 0.36 & 0.49 & 0.53 \\
$\mathrm{Fe} 2 \mathrm{O} 3$ & 4.61 & 34.50 & 36.16 & 52.55 \\
$\mathrm{MnO}$ & 0.02 & 1.40 & 1.34 & 0.81 \\
$\mathrm{CaO}$ & 0.29 & 1.16 & 1.33 & 1.41 \\
$\mathrm{MgO}$ & 0.48 & 2.92 & 2.11 & 1.36 \\
$\mathrm{~K}_{2} \mathrm{O}$ & 0.15 & 0.52 & 0.47 & 0.35 \\
$\mathrm{Na}_{2} \mathrm{O}$ & 1.88 & 3.40 & 3.13 & 2.86 \\
$\mathrm{TiO}$ & 0.02 & 0.02 & 0.04 & 0.04 \\
$\mathrm{P}_{2} \mathrm{O}_{5}$ & 0.12 & 0.87 & 1.08 & 1.00 \\
$\mathrm{SO}$ & 0.15 & 0.17 & 0.14 & 0.18 \\
$\mathrm{LOI}$ & 6.01 & 10.70 & 10.45 & 11.27 \\
\hline $\mathrm{Total}$ & 100.56 & 99.82 & 99.57 & 98.62 \\
$\mathrm{ppm}$ & & & & \\
$\mathrm{V}$ & 10 & 171 & 106 & 211 \\
$\mathrm{Co}$ & 3 & 19 & 13 & 50 \\
$\mathrm{Ni}$ & 2 & 30 & 30 & 27 \\
$\mathrm{Cu}$ & 10 & 36 & 48 & 82 \\
$\mathrm{Zn}$ & 8 & 70 & 73 & 71 \\
$\mathrm{As}$ & 11 & 118 & 108 & 93 \\
$\mathrm{Rb}$ & 4 & 9 & 8 & 6 \\
$\mathrm{Sr}$ & 38 & 264 & 270 & 300 \\
$\mathrm{Y}$ & $<3$ & 5 & 7 & 3 \\
$\mathrm{Zr}$ & $<10$ & $<10$ & $<10$ & $<10$ \\
$\mathrm{Nb}$ & 1 & 1 & 1 & 1 \\
$\mathrm{Ba}$ & 19 & 127 & 51 & 88 \\
$\mathrm{Ce}$ & $<10$ & $<10$ & $<10$ & $<10$ \\
$\mathrm{La}$ & $<6$ & 6 & 10 & $<6$ \\
$\mathrm{Sc}$ & $<3$ & $<3$ & $<3$ & $<3$ \\
$\mathrm{Mo}$ & 6 & 46 & 44 & 49 \\
$\mathrm{~Pb}$ & 9 & 10 & 11 & 12 \\
$\mathrm{Sn}$ & 5 & $<3$ & - & - \\
$\mathrm{Sb}$ & $<$ & $<2$ & - & - \\
$\mathrm{U}$ & & & 3 & - \\
\hline & & & &
\end{tabular}

Table 6

Fouquet et al.

ORGEO-2017-381 
